Portland State University

PDXScholar

1979

Self-Concepts of Institutionalized and Community

Residing Elderly

Diana L. White

Portland State University

Follow this and additional works at: https://pdxscholar.library.pdx.edu/open_access_etds

Part of the Gerontology Commons

Let us know how access to this document benefits you.

Recommended Citation

White, Diana L., "Self-Concepts of Institutionalized and Community Residing Elderly" (1979). Dissertations and Theses. Paper 2539.

https://doi.org/10.15760/etd.2536

This Thesis is brought to you for free and open access. It has been accepted for inclusion in Dissertations and Theses by an authorized administrator of PDXScholar. Please contact us if we can make this document more accessible: pdxscholar@pdx.edu. 
AN ABSTRACT OF THE THESIS OF Diana Lynn White for the Master of Science in Sociology presented November 14, 1979:

Title: Self-Concepts of Institutionalized and Community Residing Elderly.

APPROVED BY MEMBERS OF. THE THESIS COMMITTEE:
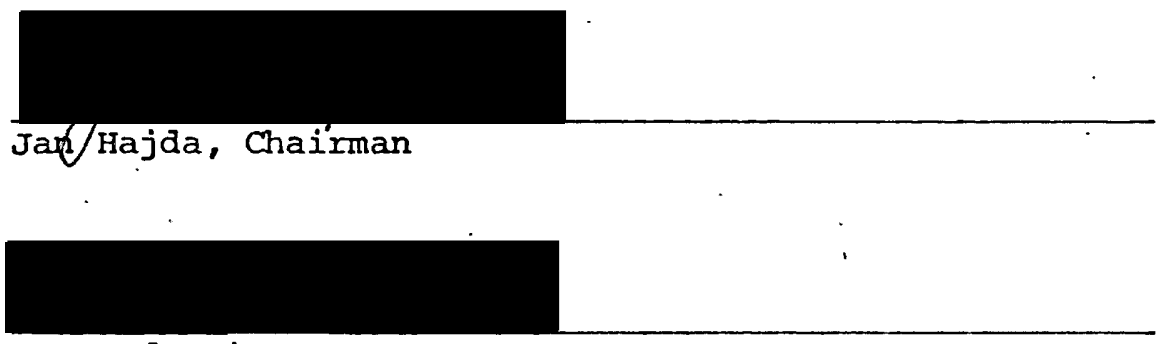

Leonard Cain

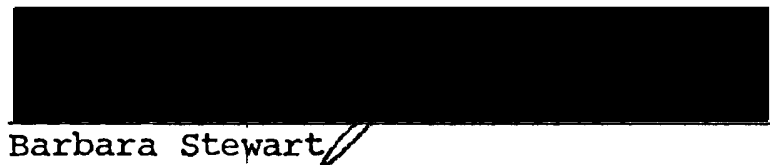

This study explores the nature of the self-concept in old age. Specifically, the relationship between the self-concept and social relationships and self-concept and living situation (residence in a long term care institution or residence in one's own home) are examined. The self-concept was measured by the Tennessee self Concept Scale (TSCS) developed by William Fitts in 1965. Data was collected at two stages (over a two to three year period) from a study sample which consisted of twelve individuals who became institutionalized and twelve individuals who remained in their own homes.

Both quantitative and qualitative data analysis methods were 
used. Analysis indicated that the study sample groups of institutionalized and community residing groups were similar in the amount and kind of social contacts they had with friends, family and relatives. Examination of the self-concept scores revealed that there were virtually no differences between the self-concept scores of the two samples. At the same time the pattern of response was quite different from the TSCS norm group. Profiles of the self-concepts showed older people to have generally positive self-concepts, particularly in the areas of moral-ethical and personal self-concepts. Large standard deviations indicate that older persons are a more diverse and heterogeneous group than those in other age groups. Case study analysis indicated that self-concept was strongly and positively correlated with satisfying social relationships. In many cases, the nature of these relationships is not accurately reflected by survey data. This qualitative analysis also indicates that the presence or absence of social relationships are often deciding factors in determining whether or not an individual will be institutionalized.

This study concludes with a discussion of the need for further longitudinal research into the nature of the self-concept in old age... and issues in methods of data collection and analysis. 


\title{
SELF-CONCEPTS OF INSTITUTIONALIZED AND \\ COMMUNITY RESIDING ELDERLY
}

\section{BY}

Diana Lynn White

A thesis submitted in partial fulfillment of the requirements for the degree of

\author{
MASTER OF SCIENCE \\ in \\ SOCIOLOGY
}

Portland State University

1979 
TO THE OFFICE OF GRADUATE STUDIES AND RESEARCH:

The members of the committee approve the thesis of

Diana Lynn White presented November 14, 1979.
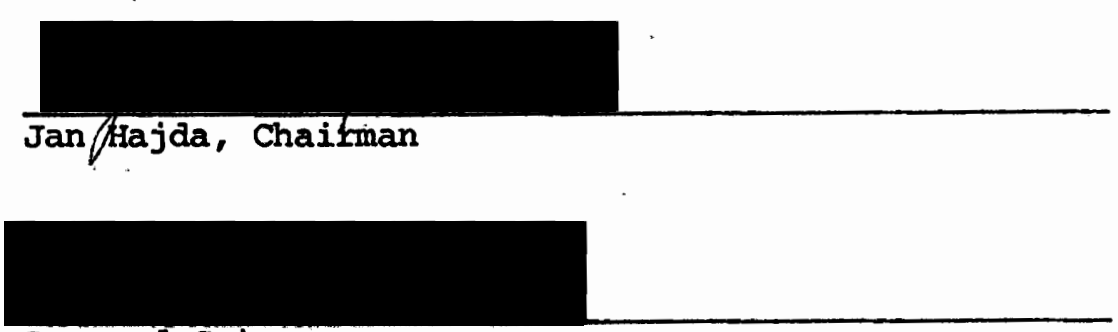

Leonard Cain

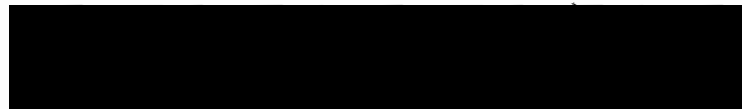

Barbara stewaft

APPROVED:

Qharles D. Bolton, Head, Departient of Sociology

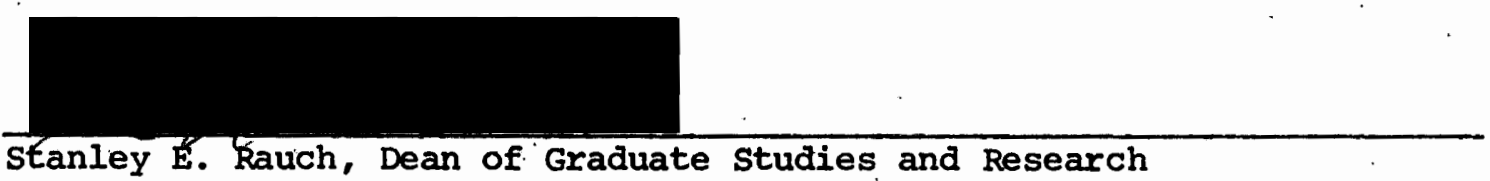




\section{ACKNOWLEDGMENTS}

I would like to express appreciation to all of those individuals who were involved in the successful completion of this thesis. Dr. Jan Hajda, Dr. Leonard Cain, and Dr. Barbara Stewart assisted in the conceptualization of the project and made important suggestions regarding procedures for seeing it through. Special recognition is due Barbara Stewart for her interest, support and enthusiasm for the study. Her willingness to teach and hex many hours spent in reading and consultation are greatly appreciated. I would like to thank Leonard Cain specifically as well for his efforts which allowed completion of the thesis this term.

Special thanks are also in order to Pat scott and Mary Boucher who spent hours typing this manuscript and were a major source of moral support throughout the entire process. Ellen Jean was also invaluable, assisting with data analysis and providing important editorial comments on earlier drafts of this thesis. I would also like to thank my friends and colleagues at the. Institute on Aging for their interest and concern with my efforts. Finally, special appreciation is extended to the 24 individuals who allowed me into their homes to be interviewed. 
TABLE OF CONTENTS

PAGE

ACKNOWLEDGMENTS . . . . . . . . . . . . . . . . . . .

LIST OF TABLES. . . . . . . . . . . . . . . . . . . . . v vi

IIST OF FIGURES . . . . . . . . . . . . . . . . . . . . v vii

CHAPTER

I STATEMENT OF PURPOSE. . . . . . . . . . . . . . 1

II THEORETICAL FRAMEWORK . . . . . . . . . . . . . 4

Role Acquisition. . . . . . . . . . . 6

Self-Concept. . . . . . . . . . . . 11

III HYPOTHESES. . . . . . . . . . . . . . . . 19

IV METHODS . . . . . . . . . . . . . . . . 22

Subjects. . . . . . . . . . . . . 22

Instruments . . . . . . . . . . . . 23

Procedure . . . . . . . . . . . . 27

Data Analysis . . . . . . . . . . . 31

V RESULTS . . . . . . . . . . . . . . 35

Sample Description. . . . . . . . . 35

Nursing Home Sample . . . . . . . . . 35

Community Sample. . . . . . . . . . . 42

Hypothesis I. . . . . . . . . . . . . 47

Statistical Analysis. . . . . . . . . 47

Qualitative Analysis of Case Studies. . . . 58 
CHAPTER

PAGE

Hypothesis II . . . . . . . . . . . 78

Statistical Analysis: . . . . . . . 78

Qualitative Analysis of Case Studies. . . . . 81

VI DISCUSSION AND IMPLICATIONS OF THE STUDY. . . . . . . 84

BIBLIOGRAPHY. . . . . . . . . . . . . . . . . . 93

APPENDICES. . . . . . . . . . . . . . . . . . . . . 98

I WELI-BEING INDICATORS . . . . . . . . . . . . 98

II STAGE 1 QUESTIONNAIRE . . . . . . . . . . . . . . 99

III STAGE 2 QUESTIONNAIRE . . . . . . . . . . . . 101

IV TENNESSEE SELF-CONCEPT SCALE. . . . . . . . . . . 104

V SUBJECT CASE STUDIES. . . . . . . . . . . . . 109 


\section{LIST OF TABLES}

TABLE

PAGE

I Frequency of Activities and Social Contacts of the

Nursing Home Sample at Stage 1... . . . . .

II Frequency of Activities and social Contacts of the

Community Sample at stage 1. . . . . . . . .

III Correlations for Single Item Variables from stage 1

to stage 2....................

IV Tennessee Self Concept Mean Scores and Standard

Deviations . . . . . . . . . . . . . .

$\mathrm{V}$ Means and Standard Deviations for Samples of

Elderly People . . . . . . . . . . . .

VI Pearson Correlations Between Tennessee Self Concept

Scores and Social Partiçipation at Stage $2 . .$. .

VII Well-Being Indicator Score Means by Group. . . . . . 


\section{LIST OF FIGURES}

FIGURE

PAGE

1. Conceptualization of study Variables . . . . . . . 23

2. Profile of Self-Concept Scores . . . . . . . . 50

3. Summary of Case Studies of the Study Sample. . . . . . 59 
CHAPTER I

STATEMENT OF PURPOSE

The purpose of this study is to examine the nature of the selfconcept in old age. Atchley (1972:89) defines self-concept as a cognitive element which is "the individual's description to himself of who he is and what he is like."* The self-concept has been viewed by many social scientists as an important construct for understanding people and their behavior. Specifically, knowledge concerning the individual's self-concept is thought to provide insight into the attitudes of the elderly toward themselves and their ability to cope with loss and adapt to change.

An important issue in the study of the self-concept concerns the extent to which the self-concept influences or is influenced by other factors. In order to explore this issue, the present study examines the relationship of the self-concept to two important factors: the individual's social relationships and the individual's living situation (i.e., residence in one's own home vs. residence in a long term care institution).

Social relationships are important to the development of one's self-concept. People come to know themselves through the response of others to them. In addition, people receive important emotional

*Note: Throughout this work sex-neutral language has been used except in cases of direct quotation and except when the subject or study is gender-specific. 
support from friends and family which contributes to their general well-being. Social relationships are particularly important as one ages and begins to experience loss in various arenas of life. The role of social relationships in shaping the self-concept is explored in depth in Chapter II, The Theoretical Framework.

Living situation in this study refers to residence of the older person either in an institution or within the community in the individual's own home. Many old people enter various long term care facilities each year. It is estimated that while only $5 \%$ of those 65 and older live in nursing homes at any one time, approximately onefourth of the elderly population will spend part of their lives as nursing home residents (Wershaw, 1976). In addition, as individuals live longer, the likelihood of entering a nursing home increases. At any one time, approximately $20 \%$ of those over 80 years of age live in institutions (Tobin and Lieberman, 1976). The prospect of entering an institution is frightening to most people and is typically avoided as long as possible. Institutionalization represents major losses such as loss of independence, health, privacy, income, home and in many cases, loss of friends. The impact of institutionalization on the elderly has been the major concern of several studies which suggest that institutionalization contributes to deteriorating mental and physical capabilities and lowered self-esteem. Tobin and Lieberman (1976) have questioned the nethods used in the studies from which these findings are drawn. They suggest that the deterioration which occurs is part of the decision-making process in which an individual is involved before entering a long term care institution. Still, for 
a variety of reasons there do appear to be differences between institutionalized and community residing elderly.

studies show that people who reside in nursing homes are older, more socially isolated, have lower incomes, and are in poorer health than the rest of the elderly population. At the same time, however, many people with the same characteristics do continue to live in the community. Therefore, in order to assess the impact of institutionalization on the self-concept of older persons, it is important to study persons in both settings who are similar in age, income, health status, marital status, etc. The population from which the sample for this study was selected consisted of people living in the community (at the beginning of the study) who had characteristics similar to many institutionalized elderly; that is, they were older, sicker and poorer than the general population. This study examines and compares the self-concepts of individuals who later entered institutions with those who remained in the community. Specifically, this study focuses on the relationship between self-concept and living situation and selfconcept and social relationships. Results will add to knowledge and understanding of similarities and differences among older people in different living situations. Furthermore, findings regarding the social relationships of the institutionalized and non-institutionalized older person will contribute useful information regarding the extent to which these relationships are associated with the process of institutionalization, the way the older person views and reacts to institutionalization, and his/her self concept following institutionalization. 
CHAPTER II

\section{THEORETICAL FRAMEWORK}

Role theory has been the basis of many studies of older people. It is useful to this study in that an individual's self-concept is based upon the self-evaluation of one's own roles and their values to other people and to society at large. Role theory assumes the presence of patterns of activity between individuals or groups of individuals. These patterns are based on both societal and individual expectations of what constitutes appropriate behavior. Two major concepts used in role theory are position (or status) and role.

Iinton (1936) defines status as a position in a particular pattern of reciprocal behavior. On another level, status may be defined as representing an individual's position with relation to the total society. Recent theorists have used the term "position" rather than "status" as defined by Linton (Williams, 1960). Biddle and Thomas (1966) define position as a unit of the social structure, or as a category of persons. Differentiation of positions is based on common attributes, common behavior, or common reactions of others toward the position holder. Physician, old person, parent, bum, student are examples of positions. Williams suggests that there are three major elements which make up a position. These are (1) role, or functional content of the position, (2) status, or moral evaluation of the position, and (3) social power, or amount of influence carried by the 
position.

According to williams (1960), position (or status) and role are inseparable. One cannot perform a role without occupying a social position. A role is a set of prescriptions defining what the behavior of a position nember should be (Biddle and Thomas, 1966). It represents the dynamic aspect of position (Linton, 1936). Similarly, a role has been defined as a "set of expectations impinging on an incumbent of a social position" (Thornton and Nardi, 1975:871). Sources of role expectations include (1) society and norms present in a cultural or sub-cultural group, and (2) those with whom one interacts. Most role behavior, then, is prescribed and expected by others. Roles and positions have varying degrees of flexibility which allow an individual to adjust to a role and also change a role to fit his/her personality. This allows some variation among similar positions and roles, although the extent of variation within a role is also dependent upon the social prescriptions and behavior of others (Biddle and Thomas, 1966). Roles include a number of rights and duties. Rights may include privileges or prestige associated with a particular position, while duties refer to obligations and responsibilities one is expected to perform. It should be emphasized that role theory is concerned with patterned activity between individuals or individuals and groups. There is an emphasis on reciprocal behavior. One cannot occupy a position or perform a role without some degree of social interaction. A position implies a complementary relationship with others (i.e., parent-child, social worker-client, employer-employee). 
Role Acquisition

Acquiring a new role, or socialization, is a learning process. A student learns which tasks must be performed in order to become a successful student; a parent learns, to some degree, the behavior that is necessary to raise a child. Brim (1976) discusses adult socialization as changes in or additions to attitudes, beliefs or behavior in response to demands of others or self. Demands for change from others may come from face-to-face interactions with significant others or from more general sources representing societal demands such as change in population characteristics or new laws. Change may also be selfinitiated, though Brim points out that this change often has its roots in the expectaions of significant others.

Thornton and Nardi (1975) suggest that there are four stages of role acquisition beginning with anticipation and followed by formal, informal and personal stages. The absence of formal roles for the elderly has been well-documented (Blau, 1973; Cavan, 1963; Rosow, 1974). Compared to younger persons there appear to be few formally defined rights and duties and little consensus on what constitutes appropriate role performance. Furthermore, aging differs from other socialization situations in that there are no rites of passage, there are a number of social losses and there is little role continuity (Rosow, 1974). However, much that is presented by Thornton and Nardi is quite important to this study. The ways in which these stages relate to aging is described in the following paragraphs.

People anticipate old age and rely on informal interaction with others and other personal resources to shape and define a set of 
rights and duties of old age. In anticipation, the first stage, a role is broadly defined, incomplete and ambiguous. Many anticipate aging with a great deal of dread and uncertainty. In a society which idealizes youth and energy those who grow old enter positions connected with a variety of negative connotations. This is especially true of those who face institutionalization. Nursing homes are feared because of the pictures of neglect, helplessness, and death which accompany them. Thornton and Nardi suggest that future adjustment to a role may depend upon the degree of accuracy of what is conveyed and perceived about the role at this stage. "Successful" aging appears to be related to one's attitudes and expectations of aging. For example, Kalish (1975) points out that fear of being alone and anticipation of a poor standard of living (whether or not such fears are realized) are both associated with lower self-esteem in older people. Different types of persons are likely to have different personal expectations of aging. Blau (1973) identifies four types of responses to aging: retreatism, alienation, conformity and innovation. These are related to such characteristics as social class, interpersonal integration and social participation. Also, Atchley (1972) names personal resilience and a humane environment as prerequisites for successful adaptation to aging. It may be argued that all of these characteristics affect an individual's personal expectations or anticipation of aging and as a result affect future responses and the ability to adjust to a new position of "old person".

In the formal stage, the individual shifts from viewing a position from the outside to viewing it from the inside as a member 
of a role set. In this stage role expectations and requirements are clearly defined, often in formal, written terms. Examples include job descriptions and professional standards. The instrumental. purposes of the role are emphasized and there is also a high degree of consensus concerning appropriate behavior and the skills and knowledge necessary for role performance (Thornton and Nardi, 1975). This stage is often absent from the socialization process in old age. People enter the roles of old age gradually, usually as the result of loss of other adult roles. Many times these losses are not compensated for by new associations. In old age there is status loss, ambiguous norms, role discontinuity, and often low motivation to acquire the new role; all of which are the reverse of optimal conditions for socialization (Rosow, 1974).

Becoming a resident in a nursing home is, in a sense, a new, formal role for the individual. Yet, in most cases there is little attempt to introduce the new resident into the system and provide him or her with clearly defined expectations concerning the rights and duties associated with the role. Efforts to do so have enabled individuals to more satisfactorily adjust to new surroundings (Kramer and Kramer, 1976; Brody, 1977), and knowledge concerning the new environment has contributed to the individual's ability to predict or control what happens to him/her. This, in turn, contributes to psychological well-being (Schulz, 1976). Still, there is a large amount of ambiguity surrounding the role of nursing home resident. It is unstructured, there is a reduction of responsibility, and role activities are limited. 
In the informal stage, Thornton and Nardi suggest that other people with similar roles (in this study, old people) are the most important to those acquiring a new role. According to Rosow (1974), there is a high degree of dependence of older people on small social groups. Blau (1973) discusses at length the importance of friendship or peer relationships in maintaining and shaping an individual's selfidentity. She suggests that participation in a network of social relationships, especially for those in older age groups, represent continuity and a degree of sameness in identity allowing them to maintain a middle-aged rather than old identity. This middle-aged identity may be maintained in spite of physical changes and very significant role losses. It is important to note that Blau discussed the maintenance of adult status and self-concept into old age and not the acquisition of new roles. Still, it is clear that informal peer groups provide an important means of interpersonal integration for older persons occupying similar positions.

Although the informal peer group influences the self-concept, Blau also mentioned that what is considered proper behavior for old people by one's associates is not highly related to an individual's conception of appropriate behavior. She suggests that the normative beliefs that influence these conceptions are not age-specific, are based in broad social values acquired in adulthood, and are not easily influenced by close associates.

Thornton and Nardi describe the personal stage as a time of flexibility within roles which allows the individual to begin shaping the role to him or herself. This stage is viewed as the most impor- 
tant in terms of adjustment to the role. At this point an individual is able to influence the expectations of others toward his/her role, achieving some degree of consensus. The authors point out that this personal stage is not necessary for role performance but is important for adjustment to the role and satisfaction with one's position.

It is likely that this stage is extremely important to those occupying a position that is poorly defined and where rights and duties are unclear. Individuals in this position are forced to take a more active part in defining their roles and are likely to depend upon interactions with significant others and their own personal characteristics. The roles that emerge are likely to have their basis in the social structure and there are obvious constraints (i.e., lack of personal resilience and/or a humane environment). However, an individual is often in a position that allows him/her an opportunity to create or at least shape many of the expectations, rights and duties surrounding the position of old person.

It is useful to present the concept of primary association developed by O'Brien and Wagner (1975). Primary associations are defined as "any pattern of enduring human interaction where content, control, and costs of a relationship represent the outcome of negotiation between participants rather than the enactment of prescribed role behavior" (p. 9). That is, relationships develop, forming a unique or individualized set of expectations, rights and duties that 19 are defined by the individual participants rather than by socially defined roles. Consensus, or the beliefs shared by participants concerning content, control, and costs is considered to be the most 
important aspect of primary associations. Consensus may be examined through study of how it is reached, the stability of agreement and the sanctions which exist. Once consensus is reached, parameters for behavior are set and are maintained as long as the association is satisfying. Primary associations may develop from formal roles or may emerge from spontaneous situations. The important point is that through primary associations (and the informal and personal stages of role acquisition discussed above), new roles are formed with consensus among the principal participants concerning behavior, rights and duties in a given situation.

When change occurs, consensus is renegotiated and a relationship is modified. This renegotiation is an important element of this study. Change, through institutionalization, has been forced upon a number of older people and, as a result, each individual has had to renegotiate or perhaps develop new primary associations. A major research question for this study is whether or not, and to what degree, new behavior expectations affect the self-concept of elderly persons.

\section{Self-Concept}

The self-concept is the major focus of this study and is now examined in more detail in terms of Role Theory. All the positions an individual occupies and the roles that accompany them contribute to an individual's identity ox self-concept. As stated previously, the self-concept is a description of an individual to him or herself of who s/he is (Atchley, 1972) based upon an evaluation of one's own roles in terms of their value to other people and to the society at 
large. The relationship with other people is important. People come to know what they are through others' responses to them. Mead (1934) discusses two stages in the development of self. An individual must first take on the attitudes of others with whom $s /$ he interacts toward him/herself. Secondly, in order to develop a complete self, the individual must also take on the social attitudes of the social group (or generalized other) to which s/he belongs.

There have been various studies of the self-concept of older people. Atchley (1972) suggests, there is support from other research, that self-concepts are often established during middle age or at a time when one occupies formal roles. Then, when these roles are no longer played, they are used as important sources of identity, representing stability of the self-concept in old age. Atchley suggests that this element of stability may help to offset negative self-concepts resulting from many of the role losses that accompany old age. Self-concepts, however, are affected by age or by factors associated with old age. According to phillips (1963), multiple role changes (retirement, widow/widowerhood, aging past 70) generally result in changes in identity-identity as old rather than middle-aged. In addition, he found that a self-concept of being old was related to maladjustment which he defines as lack of alignment between the needs of the individual and the rewards obtained. Similarly, Pihlblad (1965) found that those expressing satisfaction with their living conditions, a measure of adjustment to old age, tended to have youthful rather than old self-concepts. Blau (1974) and Cavan (1963), among others, discuss the impact of retirement on self-concept. Work, they 
maintain, is a role which is highly valued in this society. With loss of this role, society views the individual, and the individual views him or herself, as having less value and therefore as less important in old age. Payme (1963) examines the decreasing confidence men over 70 have in their own decision-making ability. These men look. instead to those in the age category of their adult children for assistance in making decisions. Middle-aged persons are generally chosen by all age groups when asked to whom they would turn for advice.

Since self-concept is formed through interactions with others, it follows that changes in interaction patterns would result in changes in self-concept. Anderson (1965) found that new surroundings, which in her study were produced by nursing home admissions, did not affect self-concept as much as reduction of interaction accompanying such change. In fact, there were no significant differences in selfconcept between institutionalized and non-institutionalized people when social interaction remained the same. Only nursing home residents who had little interaction with others had negative selfconcepts.

Family Relationships. In many cases, families are important sources of social support and are likely to maintain interaction with their elderly members. Approximately $80 \%$ of all elderly people have living children. Similarly, 758 of the elderly have children who live within a 30-minute drive. Butler and Lewis (1973) suggest that identity comes from family ties and others indicate that the family is the last remaining role that old people cling to. The influence of the 
family in the role-defining process of older people, however, and their effect on self-concept is unclear. Blau (1973) found no relationship between an older person's age identity and family conception of one's age. Similarly, contacts with adult children appear to have little influence on adjustment or life satisfaction of the elderly (Pihlblad, 1965).

Yet, a considerable amount of the literature dealing with old people and their children is fairly positive in terms of the supportive, emotional, affectional ties which exist between them. Johnson and Bursk (1977) review much of this literature and conclude that these ties are crucial integrative mechanisms for the elderly. They and others argue that demographic and other societal changes have not altered the importance of family relationships, especially in times of illness, crisis, or ceremonial occasions. Bild and Havighurst (1976: 63) suggest that "family members are without doubt the greatest resource for regular social interaction for psychological and material support and as a source of emergency aid." In their sample of urban elderly they found weekly contact between parents and children and many instances of mutual assistance in the form of gifts, care of sick offspring, etc.

At the same time, Hawkinson (1965) found that the elderly in a small town had only monthly contact with children. They wanted more frequent intimate contact with children, but did not expect it. Hawkinson suggests that these unfulfilled wishes contributed to feelings of isolation and dependency, which in turn negatively affected feelings of self-worth. 
The literature, then, is inconclusive both about the nature of the relationship of old people and their children and about the effect of this relationship on the process of role definition and selfconcept. The fact that most old people have adult children suggests that there is a potential for kinship and affection. Butler and Lewis (1973) point out that emotional ties have developed over several years and may be either positive or negative. Thus, like self-concept, family ties may be established during early or middle-aged years and remain fairly stable into old age. Still, the issue of family influence on role definition and self-concept remains problematic-perhaps as a result of the ambiguous nature of being old. The fact that there are few formally defined roles and no consensus about behavioral expectations in old age is difficult for an old person, but it is also difficult for those with whom the individual interacts.

Smith (1965) discusses the family and kinship as a social institution that embraces cultural norms of mate selection, marriage, childbearing, family maintenance, etc. Individual families, however, form mutual expectations which arise from interactions with one another. These interactions may conform to, evade, or modify norms and values of the kinship-family institution. Smith goes on to say that "interaction may proceed where rules and guides are lacking and become patterned sufficiently to give rise to new norms and values" (p. 143). Thus, the relationship of elderly parent and adult child depends upon the informal and personal stages of role acquisition described earlier and will likely be influenced by expectations formed earlier in the life course. 
Sick Role. Through interactions with others, one assumes attitudes of significant others and also the society at large toward one's role or position. Body image and/or health status also affect self-concept. According to coe (1965) $80 \%$ of those over 65 have at least one chronic disease. These conditions may mean limited mobility, stamina, mental abilities, etc. All of these may affect the individual's ability to fulfill one's own and others' expectations. This in turn may influence feelings of self-worth or the self-concept.

The role of disabled person represents another ambiguous position that many older people occupy. In his study of the sick role, Gordon (1966) found two distinct, unrelated sets of behavioral expectations. In the first, the sick role, prognosis is serious and uncertain. This is the sick role described by parsons where the sick are: (I) exempt from social responsibilities, and (2) are not expected to care for themselves. At the same time they are expected to (1) want to get well, and (2) seek competent help. The second is an impaired role where health is impaired, but the prognosis is not serious. The elderly, for the most part, fall into this impaired category. Gordon found less agreement on how to behave when one is "impaired" than when one is "sick". There does appear to be an emphasis on independence and maintenance of normal activities. At the same time, however, Gordon suggests that when someone is defined as being "impaired", s/he may be denied certain supports. In addition there is some discouragement in seeking medical care. This may be very important to older people, especially when the elderly are stereotyped as disabled and impairments are viewed as natural, inevitable processes of aging. 
Summary and Implications

A role is a set of expectations that is socially defined in terms of one's status or position. One must learn these expectations and the accompanying rights and duties through socializațion or role acquisition. Where roles are poorly defined, such as they are for the elderly, and consensus concerning appropriate behavior is low, the informal and personal stages of the role acquisition and primary associations are especially important. Through these steps individuals and others with whom they interact negotiate a sometimes unique set of expectations and establish parameters for appropriate behavior. These new roles are likely to be influenced by the roles and the individual's self-concept that precede them. Interaction with others is crucial. Roles are not defined and self-concepts are not formed without this prociess.

Many factors influence interaction--health, mobility, number, of friends, and affective quality of a relationship. It appears that interaction with peer groups, or with other old people, is important in determining age identity, although these factors have less influence in an individual's determination of appropriate behavior. The role of the family is unclear. They appear to have little influence on age identity and adjustment to age, but they do represent continuity of formal kinship roles, although responsibilities and expectations change and must be renegotiated. In addition, much of the literature describes the many affectional and supportive ties that exist between old people and their children as vital for social integration. Interaction is important for role definition, especially in a 
new surrounding--in this study, nursing homes. Peer groups are made up of other nursing home residents who are usually unknown to individuals prior to institutionalization. Interaction with these residents and with the staff will help define the role of institutionalized person. The quality of interaction is likely to affect self-concept. In addition, family relationships represent continuity, ties with past roles and self-concept. These ties with the family are likely to become one of the most important factors in nursing home adjustment. Thus, if an individual has a positive self-concept and affectional bonds with the family prior to institutionalization, and these bonds are maintained through interaction after institutionalization, new roles are likely to be defined and negotiated in such a way that a positive self-concept is maintained. 
CHAPTER III

HYPOTHESES

From the literature presented earlier, it appears likely that self-concepts are formed by middle age and remain fairly stable into old age. Changes in self-concept probably occur only when circumstances force changes in expectations and behavior between the old person and important people or primary associations. This refers specifically to institutionalization which may result in significantly lower levels of interaction with friends and family. This may occur for several reasons. The institution becomes the primary care giver which may displace previous roles of family and friends. This may result in reducing the amount of time relatives and friends feel compelled to visit with the old person. In addition, visits from friends may become problematic because of poor health and/or transportation difficulties. Similarly, loss of a telephone may destroy a very important link with others. Geographical distance between the family member and nursing home as well as differences between schedules and routines may also lead to a reduction : in interaction. Each of these and other circumstances will force the principal participants to renegotiate expectations of one another in order to form a new consensus concerning the rights and duties of each. Outcomes may or may not be mutually satisfying. However, if there is less contact and less opportunity for interaction, the self-concept of the old person is 
likely to decline. Thus, it is hypothesized that institutionalized individuals who experience decreases in the amount and kind of interaction with friends and family will have less positive self-concepts than those who live in their own homes and/or maintain these relationships.

In discussing social supports and institutionalized individuals, another issue is implied; that is, what is the role of the social support system in the process of institutionalization? It is well documented that those in nursing homes seem to be older, in poorer health, less likely to have children and be more socially isolated. Yet many older people with these characteristics do maintain themselves in their own homes and, similarly, a great number of nursing home residents do have family and friendship ties outside the nursing home. In order to more fully explore the influence of social supports in the process of instititonalization, a second hypothesis was generated. Findings from data analysis by Whitelaw and stewart (1978) indicated that the major predictors of institutionalization were poor cognitive status and/or impaìred daily functioning $(p<.001)$. These measures and analyses are described under the data analysis, but from this study it was hypothesized that:

(a) individuals who were predicted to become institutionalized (due to poor health and/or cognitive status), but remained in their own homes were more likely to have strong social supports than those who remained in their homes or those who entered nursing homes as predicted; and 
(b) those who were predicted to remain in their own homes, but were institutionalized were more likely to have little social support compared to those who remained in the community or those who were institutionalized as predicted. 
CHAPTER IV

METHODS

\section{Subjects}

This study followed 24 older people over a three to four year period. These individuals were part of a larger study $(n=397)$ conducted by the Institute on Aging (A Longitudinal Study of a High Risk Urban Elderly Population, 1978). Information for the larger study was collected in three waves. The study for this thesis was concerned only with Waves I and III and will be referred to as Stage 1 and stage 2 . By Stage 2 there were 227 survivors (individuals still living in their own homes), and 40 persons who had been. institutionalized.* This study follows 12 individuals in each group. A more complete description of the sample is given in the chapter on Results.

\section{Instr nents}

Independent Variable. The independent variable in this study is the living situation at stage 2 . This was operationalized by deterining whether or not the individual lived in an institution (nursing home or home for the aged) or in his/her own home or apartment.

Social contact or social participation variables were viewed as both independent and intervening variables (see Figure 1). These were

*There were also people who had died $(n=39)$, were too ill to be interviewed $(n=27)$, or refused to continue $(n=51)$. These individuals were not included in this study. 
STAGE I

STAGE 2
Family/Friend Relationships

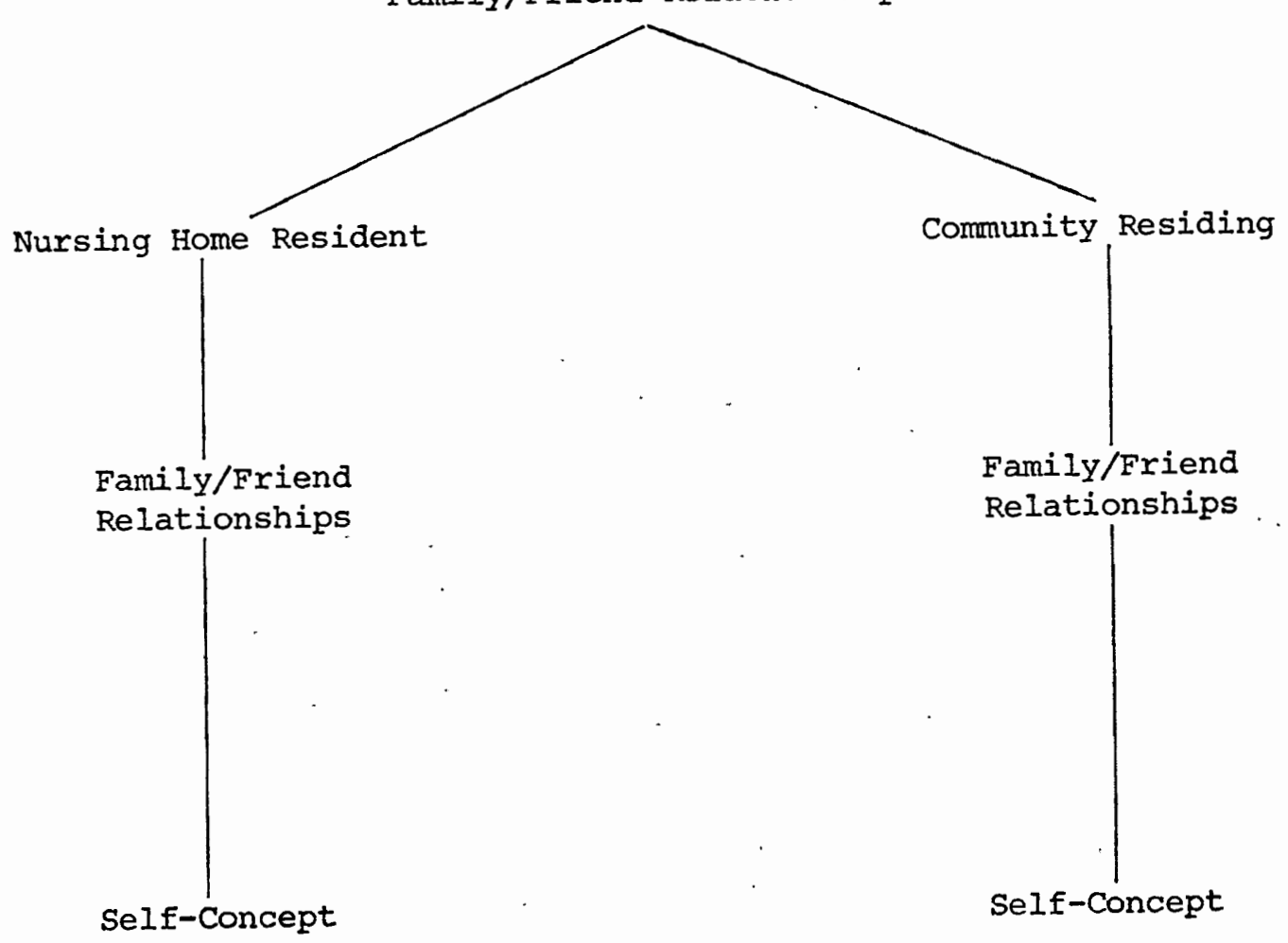

Independent

Variable

Independent Variable

Intervening Variables

Dependent Variable 
measured by interaction patterns with family, friends, relatives, and others at Stage 1 and stage 2 .

The social contact variable of major interest was one of eight well-being indicators developed from analysis conducted by whitelaw and Stewart (1978) on data from the larger study. Although the variable of major interest was the social contact variable, the other indicators were also used in analyzing data for this study. The eight scores were: medical health status, cognitive status, daily functioning, activities, social contacts, life satisfaction, income, and housing. A more complete description of the items used in constructing these indicators is presented in Appendix I. Specific questions examined from stage 1 data are included in Appendix II. There are a number of reasons for using the well-being indicators for comparing the two samples. First, composite scores, based on three or more items, are more reliable and more theoretically meaningful than single item measures (Whitelaw and Stewart, 1978). Also, by using these indicators, problems with missing data are minimized. Finally, previous analyses using these measures have shown them to be sensitive to differences between subgroups being examined (Whitelaw and Stewart, 1978; Chapman and Walters, 1978).

In addition to these indicators, questions concerning social contacts were asked at stage 2 . These questions concerned confidants, amount of contact with family, friends, and relatives, and satisfaction with these relationships. Nursing home respondents were also asked about interaction with other residents and the quality of the relationships. The interview schedule used at stage 2 is in Appendix III. 
Dependent Variable. Self Concept was measured at Stage 2 by the Tennessee Self-Concept Scale (TSCS) developed by William Fitts in 1965 (see Appendix IV). The scale is made up of 100 self-descriptive statements with a five point response scale: mostly false, completely false, partly false and partly true, mostly true, and completely true. Ten items were drawn from the MMPI L-scale and provide a selfcriticism score. The remaining 90 items were drawn from a large pool of self-descriptive statements. The criterion for use was agreement by seven psychologists on the classification of each item on the basis of content.

Each item was classified in terms of (1) positive or negative position of the statement (there are 45 positive and 45 negative statements); (2) the internal frame of reference; and, (3) the external frame of reference. The internal frame of reference items provide information about an individual's identity, self-satisfaction, and behavior. The five categories in the external frame of reference are the physical self, the moral-ethical self, the personal self, the family self, and the social self.

This classification system evolved into a three-by-five grid. The three internal referents make up one dimension (the row scores) and the five external categories (the column scores) make up the second dimension, resulting in 15 intersecting categories (i.e., selfsatisfaction/family self). There is an equal number of positive and negative items in each category.

A major advantage to using this scale is the wide variety of scores which can be derived. These include: 
1. Positive Scores which reflect overall levels of self-esteem. This includes the Total Positive Score and subscores which indicate self-esteem in each of the eight areas described above (row and column scores)

2. Variability Scores provide a measure of the amount of the inconsistency from one area of self-perception to another. Variability scores are given for total variability, as well as for rows (internal reference) and columns (external reference):

3. Distribution Scores summarize the distribution of scores across the five response categories (completely false to completely true) and provide information regarding the certainty with which one views oneself.

4. Self-Criticism Scores indicate either defensiveness or openness to admitting negative attributes.

5. Conflict Scores reflect response to positively and negatively expressed statements. Some respondents, for example, may describe themselves by affirming positive attributes but may be unwilling to deny lıgative ones or, conversely, may deny negative qualities but be unwilling to affirm positive ones. The Net Conflict Score measures the amount and direction of conflict. The Total Conflict score sums scores non-algebraically in order to determine if variable conflict scores have cancelled each other out.

Reliability and validation procedures have shown the TSCS to be a reliable and valid instrument (Fitts, 1965). However, it is important to note that there may be important questions concerning the validity of the instrument as it was used in this study. As with many psychometric tests and instruments, the TSCS was designed from data on 
a norm group largely made up of young, male college students $(n=626)$. The test may be cohort specific and therefore interpretations based on the manual may not be valid (Schaie and Schaie, 1977). Another consideration involves the way the TSCS was administered. As discussed below, the instrument was designed to be self-administered, but for several reasons was read to respondents by the interviewer. Although serious question concerning reliability and validity might be raised, the scale items seemed meaningful to the respondents and in most cases they were able to respond to them without difficulty. It was felt that using the TSCS in this study would contribute to knowledge concerning the self-concepts of older people and that use of the instrument would provide information which would assist in addressing the issues of validity and reliability in future studies.

\section{Procedure}

Stage 1 (Wave I) data collection for the total sample $(n=397)$ took place between June and August 1975. The interviews were conducted by Wes ${ }^{2}$ Coast Community Surveys of Berkeley, CA. Criteria for selecting respondents included dominant physical disorders, restricted mobility, little social contact and/or no linkage to social services. Income and living arrangements were also important criteria for sample selection. The resulting study population was older, poorer, and sicker than the general elderly population, but similar to marginally subsisting elderly found in mid-sized communities. Over 2,000 persons were screened and, following the criteria described above, there was a resulting pool of 892 persons. A total of 397 individuals were traced, contacted and interviewed. 
By Stage 2, June 1977, 40 of these 397 persons had entered long term care institutions. Follow-up on these 40 persons, by the author of this thesis, resulted in 12 completed interviews for this study. An additional five interviews of institutionalized persons were begun and not completed due to their health and/or problems with hearing. At least four individuals were no longer in the Portland area, at least two had returned home, some had died and for others there was no information available concerning where they lived.

Before conducting interviews, each nursing home or home for the aged involved was contacted (a total of ten institutions) and informed of the study. Some referred the interviewer to a nurse; one to an activity director. In one nursing home the resident was called to the phone to indicate whether or not she wanted to grant the interview. All granted permission.

The next step involved a visit to each resident prior to the interview. The purpose of this visit was to get acquainted, explain the study, and set a time and date for the formal interview. This initial visit was determined to be a vital step. There is very little privacy in institutions and many times residents are not in a position to make decisions. The initial visit allowed the individual a choice of whether or not to proceed.

Thus, each nursing home resident or home for the aged resident was visited at least twice. In some cases, it took two or more sessions to complete the interview. This occurred because of fatigue, nursing home routine or visits from relatives. In one case, the individual was visited five times. Most interviews, however, were completed after two visits. When more than one visit was required to complete the TSCS, 
an informal reliability check was done by asking the individual on the second visit to respond to items completed on the first visit. In almost all cases, responses were the same. The interviews with the institutionalized sample were conducted in September and October 1977, and March 1978.

A matching community sample was drawn from those who were still living in their own homes. An attempt was made to match people in age, sex, and marital status. This was somewhat difficult. One man in the community was married whereas his nursing home counterpart was widowed. The closest matches for four nursing home women were women who were nearly ten years younger. With these exceptions, matching on the specified variables was done.

Stage 2 interviews for the community residing sample were collected in two parts. The first part was collected as part of the larger study and involved questions concerning family/friend interaction, health, and living situation. Interviews were conducted by the Center for Population Research and Census during July and August 1977. In part $\iota \cdots 0$, the Tennessee Self-Concept Scale was administered to these individuals by the author of this thesis. In this part of the study, individuals in the community sample were contacted by telephone and interview appointments were made. Two individuals had unlisted phone numbers and so visits were made to their homes much like the visits for nursing home residents. In the course of setting up interviews, there were six refusals, three disconnected phones, and several more deaths, and changes of residence. This is indicative of the frailty of this population. Ten of the twelve interviews were completed in one session. Two required two visits. These interviews were conducted 
in March, April, July, and August 1978.

Although designed as a self-administered scale, the Tennessee Self-Concept Scale was read to the subjects in all interviews. The decision to do this was based on several factors. First, many older people are not familiar with this type of questionnaire. Responding within categories ranging from completely false to completely true appeared to be confusing and it was necessary for the interviewer to record responses and place them in the correct category. Second, both poor eyesight and hearing loss make interviewing the elderly difficult. In this study it was felt that reading the TSCS to respondents would alleviate problems of poor eyesight. Two individuals did not complete the instrument because of hearing problems and were not included in the analysis. However, it is doubtful that these individuals would have been able to complete it as a self-administered scale. In one interview where the respondent was hard of hearing, the questions were read while the respondent looked at the interview.

Finally, reading the interview added an informality that was important. Many of the items appeared to stimulate thoughts and reactions which helped in gaining understanding of the person; how s/he felt about his/her family, friends, and living situation. Many people gave considerable thought to their responses; others answered quickly. Total interview lengths ranged from thirty minutes to two or more hours. Many of the interview sessions were quite lengthy and were not limited to the formal interview schedule; there was discussion of family, plans for the future, and thoughts about past experiences. Information generated from this discussion added depth to the data collected. 
There was concern about consistency in recording verbal responses to the Tennessee Self Concept Scale. Because the response range was confusing, individuals were only asked to indicate whether each statement was true or false in describing themselves. A decision was made that when responses to the statements were "yes" or "no" they would be recorded as "completely true" or "completely false," respectively. If there was any qualification, such as, "well, I guess so" or "yes, sometimes" or "I guess I'm satisfied--I can't change it," responses were recorded in the more moderate categories of "mostly true" or "mostly false." The "partly true-partly false" category was used for such responses as, "I'm pretty mediocre," "I am calm, but I'm not easygoing." Many of the statements fell into the extreme categories. Studies reported by Thompson (1972) and Grant (1967), however, indicate that this is a typical response pattern for older persons.

Respondents generally answered all questions. Approximately five individuals did not answer one to four of the one hundred items. In most cases, they refused because they felt a particular item was not applicable to them. Some items could be filled in by the interviewer on the basis of other comments and responses. In most instances of non-response, however, the modal response for the item was used to fill in missing data. Because of the distribution pattern, the modal response was judged to be the best representation of the sample.

Data Analysis

Data were analyzed using both quantitative and qualitative methods. In quantitative analysis, the first step was to determine the similarity or difference between the study sample $(n=24)$ and the larger study 
$(n=267)$. To do this, $t$-tests were computed comparing mean scores on the life space indicators of the institutionalized and surviving study sample with the institutionalized and surviving sample from the larger study.

The next series of analyses was performed in order to test the first hypothesis that institutionalized individuals who experience decreases in the amount and kind of interaction with friends and family will have less positive self-concepts than those who live in their own homes and/or maintain those relationships. The consistency in patterns of social contacts was examined by computing Pearson correlations for each group (institutionalized and community) to determine if the amount of social contact at stage 1 was correlated with social contacts at Stage 2. In addition, one-way analysis of variance was employed to identify differences between mean social contact scores of the institutionalized and surviving groups at both stage 1 and stage 2 .

In the next phase of the study, one-way analysis of variance was used to identify differences in the means of various TSCS scores. Following this step, self-concept scores were correlated with social contact scores. Then, to further clarify the relationships between social contacts, living situation, and self-concept, a multiple regression analysis was conducted. This was done in spite of the small sample size because the multiple regression analysis is a strong test and would reveal statistical patterns of interest to this exploratory study. Total self-concept, row scores, and column scores were dependent variables. Predictors were social contacts at stage 1 and 2, and living situation. A third predictor was constructed by multiplying 
living situation by social contact. This variable was useful for identifying whether or not living situation and social contact interact to produce an additional significant effect on self-concept.

The second hypothesis for the study was (a) individuals who were predicted to become institutionalized (due to poor health and/or cognitive status) but remained in their own homes were more likely to have strong social supports than those who remained in their homes or those who entered nursing homes as predicted, and (b) those who were predicted to remain in their own homes but were institutionalized were more likely to have little social support compared to those who remained in the community or those who were institutionalized as predicted. To test this hypothesis further, analysis was done on the data reported on by Whitelaw and stewart (1978). The authors used discriminant function analysis to identify predictors of institutionalization. For this study, the data were examined further through analysis of variance to determine if social contact scores were significantly different between those who fell into predicted outcome groups and those who did not. 'H11s process is described in more detail in the chapter on Results. qualitative Analysis was quite important to this study due to the small sample size and the caution required for drawing conclusions from statistical analysis. The case study approach in and of itself, however, is a useful and vital step in gerontological research and should be used in conjunction with survey data (Wagner and White, 1978). Case studies stimulate new insights and new ideas and add depth to the data by providing the researcher with broader experience (Goode, 1952). Most importantly, however, case studies can prevent important information from being lost in statistical analysis. 
There are numerous shortcomings associated with survey research, a common method of collecting and anlyzing data in gerontological studies. First, although the survey method can achieve greater precision in measurement and provides data which are easier to handle in analyses, there are also restrictions on the kind of information gathered. Similarly, artificial parameters are often imposed on the measurements made. This is a major weakness, particularly when studying the elderly, a large heterogeneous group. Older people have a wide variety of experiences, attitudes, and behaviors. Changes that occur in old age are often part of a complicated and complex process that is not adequately captured through use of survey instruments.

A second important issue is the response of many older people to survey instruments. Moen and Moen (1977) suggest that direct questions concerning needs and living situation of the elderly often do not result in accurate information. In addition, direct questioning often does not encourage respondents to provide information that is helpful in understanding an individual's own unique experience. By conducting the interviews used in this study in an open-ended, flexible mannex, respondents volunteered a considerable amount of information. That, in addition to responses to the survey instrument, enabled case histories to be compiled which are important in interpreting the results of this study. 
CHAPTER V

RESULTS

The results of this study are presented in three major sections. In the first, a sample description of the institutionalized and community samples is presented. This is followed by a section on each of the hypotheses. Within each of the latter sections there are two parts: the first reports on the statistical analysis and the second on the qualitative data.

\section{SAMPLE DESCRIPTION}

Nursing Home Sample

Stage 1. The average age of the nursing home respondents at the beginning of this study was 81 years. There were 10 women and 2 men. Seven of the women were widows at the time of the first interview. Only 2 of tne women were married at stage 1 and one of these became a widow shortly before she entered the nursing home. One woman had been divorced when she was a young woman. One of the men was a widower and the second was separated (although at the time of the second interview he discussed his wife at great length, and did not indicate that they were separated).

Only 3 of the 12 had spent their childhood in Oregon. One woman had grown up in Sweden and the rest came from other parts of the United States. The mean length of time in oregon was approximately 20 years. People had been in their homes and neighborhoods an average of five to 
ten years. Eight of the twelve had been raised on farms. All had at lease one sibling (range 1-10), with the mean number being six. At the time of the first interview, two had no living siblings and the mean number of siblings still living was two.

The respondents in this sample had worked in a varfety of jobs. Two had held administrative positions, three had been sefvice workers and three had never worked full time. The remaining four occupations were clerical staff, craftsman, operative, and private household workers.

Eight of the twelve respondents had children; six had only one child, one had two, and one had four. Six respondents also had grandchildren. None of the nursing home sample respondents lived with their children prior to entering the nursing home. At stage 1, all reported having at least one confidant; six said they had one and one indicated having eight or more.

Respondents were asked whether or not they were able to go out by themselves. Six indicated that in spite of health problems they were able to go out alone. Three people were able to get out if they had help and the remaining three were housebound. Of the categories given, the respondents had been to the grocery store and the bank most recently (Table I).

The respondents, for the most part, seemed to have frequent, personal contact with neighbors, friends, and others (Table I). All but one had visited in person with neighbors within the week prior to the interview. Nine had also visited with a friend during that time. Two of those with children had visited children in person in the preceding week and five others had seen children within the past month. The 
TABLE I

FREQUENCY OF ACTIVITIES AND SOCIAL CONTACTS

OF NURSING HOME SAMPLE

AT STAGE 1

NURSING HOME SAMPLE

\begin{tabular}{|c|c|c|c|c|c|c|}
\hline & $\begin{array}{l}\text { More } \\
\text { than } \\
\text { one } \\
\text { year }\end{array}$ & $\begin{array}{l}\text { During } \\
\text { the } \\
\text { last } \\
\text { year }\end{array}$ & $\begin{array}{l}\text { Last } \\
\text { six } \\
\text { months }\end{array}$ & $\begin{array}{l}\text { Within } \\
\text { last } \\
\text { month }\end{array}$ & $\begin{array}{l}\text { Last } \\
\text { week }\end{array}$ & $\begin{array}{l}\text { Don't } \\
\text { know }\end{array}$ \\
\hline $\begin{array}{l}\text { When was the last } \\
\text { time you went to the: } \\
\text { 1. grocery store } \\
\text { 2. pharmacy } \\
\text { 3. post office } \\
\text { 4. bank } \\
5 . \text { bus stop } \\
6 . \text { restaurant } \\
\text { 7. church } \\
\text { When was the last } \\
\text { time you spoke in } \\
\text { person with: } \\
\text { 1. netghbor } \\
\text { 2. children } \\
3 . \quad \text { relative } \\
4 . \quad \text { friend } \\
5 . \quad \text { other person } \\
6 . \quad \text { someone on the } \\
\text { telephone }\end{array}$ & $\begin{array}{l}2 \\
2 \\
5 \\
2 \\
7 \\
4 \\
8\end{array}$ & $\begin{array}{l}2 \\
3 \\
4 \\
1 \\
3 \\
1\end{array}$ & $\begin{array}{l}0 \\
3 \\
2 \\
1 \\
1 \\
2\end{array}$ & $\begin{array}{l}1 \\
5 \\
2 \\
1 \\
1 \\
2\end{array}$ & $\begin{array}{r}11 \\
2 \\
3 \\
9 \\
9 \\
10\end{array}$ & 1 \\
\hline
\end{tabular}


remaining person had seen her child within the last six months. For six of the respondents, it had been over a year since they had seen relatives. Three had visited with relatives within the last week, two within the last month and one within the last six months. All had used the telephone, with ten calling someone in the preceding week and two within the last month.

On the whole, people did not appear to have a great many concerns. The most frequently mentioned were (1) concerns for others $(n=7)$, fear for one's own health $(n=6)$, and (3) having proper locks on the doors $(n=5)$. Only one person said she often worried about money and seven reported never worrying about money. At the same time, eight respondents reported that they just managed to get by on their income. Only four said that they had money left over at the end of the month. In addition, six indicated that they were worse off than they had been ten years ago. However, most $(n=9)$ felt that their financial status was about the same as that of others their own age. Individuals were also asked to respond to a number of life satisfaction indicators. Two-thirds disagreed with the statements "I'm just as happy as when I was younger" and "I expect new and pleasant things to happen to me in the future." The "disagree" and "agree" responses were fairly evenly divided between the statements "I would not change the past even if I could" and "as I grow older, things seem better than I thought they would be."

Stage 2. Those individuals in the nursing home sample had been living in the institution from three months to two years, and the 
average length of stay was 8.4 months. Most respondents (8) rated the nursing home as being very good or good while four rated the homes as fair or poor. Most reported being very satisfied (4) or somewhat satisfied (5) with the facilities where they lived. In terms of improvements that could be mąde, respondents were generally vague. Three mentioned food, but others made comments like "If I have to be in a nursing home, this is a good place to be," and "I want to leave; it's too cold in this part of town."

People had entered nursing homes by different routes. Only one person reported being the principal decision maker in the move ("I didn't want to live with relatives"). One other person moved from a nursing home to a home for the aged and gave the impression that she had made this decision. However, her options were limited because her home had been sold while in the nursing home; an event that she did not feel she controlled.

Other persons mentioned in the move to the nursing home included family (2), physicians (4), service providers (3), and a conservator (1). L though other people were mentioned in the institutionalization process, it would be a mistake to assume that in all cases the older people were only minimally involved. Five of the twelve seemed to accept the necessity of residing in the nursing home and appeared to be involved in or at least informed about the location process as it occurred. Three individuals reported that they were planning to move from the nursing home but only one person actually had concrete plans and a place to move. The other two were vague and uncertain. A note of caution is important. The information on entering the nursing home was based on the reports of the older person after he or she was a 
resident. In an effort to come to terms with institutional placement, it is possible that these individuals viewed themselves as more actively involved than they actually were. This perception of involvement might also explain the amount of satisfaction expressed concerning living in the institution.

Half of the nursing home respondents (6) reported being in good health for their age compared to five at stage 1. Two, compared to three, reported their health as being poor while the number reported being in fair health (4) remained the same.

At the time of the first interview, 10 of the 12 individuals had talked with someone on the telephone in the past week. After being in the nursing home, three people reported using the phone daily (two had phones in their rooms) and one other used the phone about once a week. The remaining respondents never used the phone (3), or used it monthly (1), or less than monthly (3).

Four people indicated that there was no one they could call if they needed help. Of the eight who could call someone if they needed help, four mentioned children (half of the respondents with children) and staff, relatives, friends, and clergy were each mentioned once. When asked "Is there someone you can talk to about anything that bothers you?" three said no, three named clergymen, two indicated children, and staff, relative, roommate, and friends, were each mentioned once.

When asked about relationships with other residents in the nursing homes where residents lived (in ten facilities), most indicated being somewhat satisfied (5) or very satisfied (3) with these relations. However, only two of the respondents, who happened to live in the same 
facility, reported visiting with and being actively involved with other residents. Four said that while they did not visit with other residents, many living in their facility did, and five indicated that no one visited with one another.

Questions concerning relationships with children, friends, and relatives were asked. Five of the eight persons with children reported being very satisfied with these relationships. One person indicated being somewhat satisfied, one was somewhat dissatisfied and one was very dissatisfied. The last time respondents had spoken in person with their children ranged from more than a year ago (one person) to the day before the interview (one person). Other responses were: in the last six months (2), in the last month (2), and in the last week (2).

Three people said that they usually speak to their children (on the phone or in person) every day and two others speak with them every week. For two people there is contact about twice a year, and one person spoke with children less than once a year.

Visits with children took place frequently for half the respondents (daily, 1; weekly, 3) and twice a year or less often for the remaining. Five of the eight indicated that they had seen their children about the same since entering the nursing home; one had seen them more often; and two had seen them less often.

Most of those responding to questions about friends indicated being very satisfied with these relationships, although most reported seeing friends less often than they had prior to institutionalization. Two people had seen friends the day before, and three had seen friends in the last week. These people normally spoke with friends either in person or on the phone every week. For at least three others (probably 
five) it had been more than a year since they had visited in person with friends.

Five nursing home respondents had seen relatives at about the same frequency as they had prior to nursing home admission. Four others saw them less often and in two cases more often following institutionalization. For half the respondents, visits took place less than once a year. Two saw relatives about twice a year, one visited with them once a month and two saw them each week. People spoke with relatives with slightly more frequency, with two people speaking with them daily, one weekly, and one monthly.

\section{Community Sample}

Stage 1. The average age of the community (or surviving) respondents, at the beginning of the study was 76.6 years. As in the nursing home sample, there were two men and ten women. Three of the respondents were married (including both men) and one was divorced. The remaining eight were widows. These individuals were selected because they were similar to the nursing home sample.

Four of this group had spent most of their childhood in Oregon. One person had grown up in Germany and the rest had come from other parts of the United States. One person had spent all of her life in Oregon; nine had been in oregon more than twenty years and the remaining two had been in oregon between ten and twenty years. The community sample respondents had lived in their homes and neightborhoods longer than the nursing home sample. The mean length of time in their house or apartment was approximately ten years and the mean category for length of time in the same neighborhood was ten to twenty years. 
Most of the respondents had worked. Jobs ranged from administrative work, craftsperson, clerical, to work for private household. Education ranged from 4 to 13 years, with a mean education of 8.6 years of school. As in the nursing home sample, all had had at least one sibling (one individual had 21) with a mean number of six. At the time of this interview, the mean number of living siblings was two with the range from one to four. Two no longer had living brothers or sisters.

As in the nursing home sample, eight respondents had children; three had one child each, three had two children, and two had three. Two of the respondents were living with children. Unlike the nursing home sample, eight rather than all of the twelve reported having a confidant. Three people had one confidant, two had two, two had three confidants, and one reported having five.

Seven respondents reported that their health was good for their age, four said it was fair and one person who was homebound reported that her health was poor. Two respondents were able to go out with help waile most (9) were able to go out alone.

Compared to the nursing home sample, the survivors appeared to have been out of their homes more recently. In the week preceding the Stage 1 interview, the community sample was more likely to have been to the bank, to a restaurant and to church (see Table II). This is similar to the findings reported by Whitelaw and stewart (1973) that the institutionalized sample had a lower activity level at stage 1 . Contact with friends, relatives, and others seems to have also occurred shortly before the interview (see Table II). For the community group, children were likely to have been seen the week prior to the 
TABLE II

FREQUENCY OF ACTIVITIES AND SOCIAI CONTACTS

OF COMMUNITY SAMPIE

AT STAGE 1

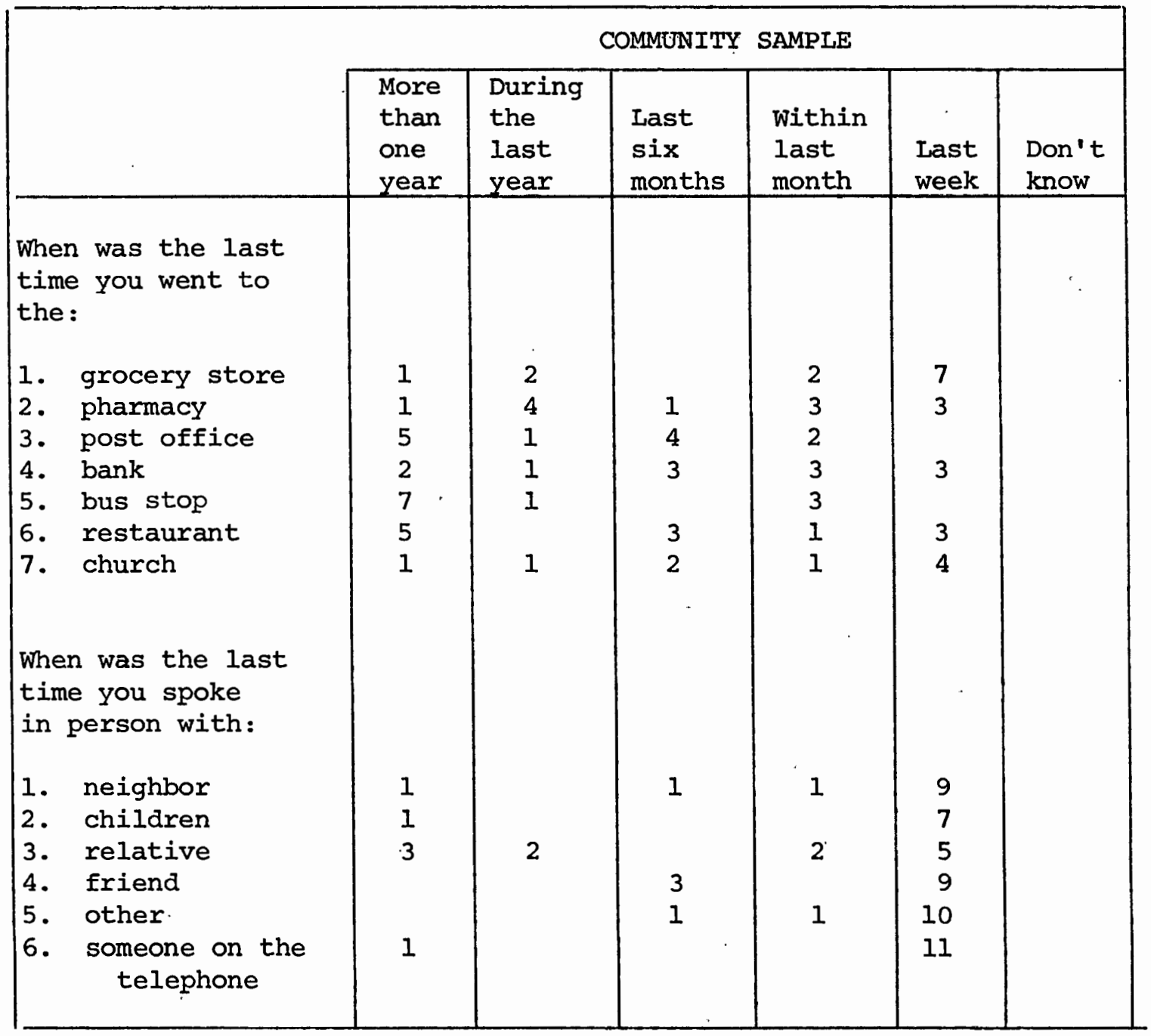


interview compared with most of the nursing home respondents for whom it had been a month. The community sample had also seen relatives more recently. Half of the nursing home residents had not seen relatives in over a year and one-fourth had seen them in the past week. These figures were reversed for the community sample; five had seen relatives in the past week, while for three it had been more than a year. The pattern for visiting friends, others, and using the telephone were similar, although one person in the community sample had not used the phone in over a year.

The major concerns of respondents in the community sample were for their friends, concerns for their own health, and concerns about walking in their neighborhoods. Unlike the nursing home sample, money was also identified as a concern. Most (7) felt their level of living was about the same as for other people their age, although one-fourth (3) felt it was worse. Half the respondents felt they were worse off than they had been 10 years earlier and most (10) felt they were in about the same position they had been in the year before. responses to the life satisfaction indicators were somewhat more positive than the nursing home sample. About half ( 7 and 6 , respective1y) agreed with the statements, "I'm just as happy as when I was younger" and "I expect new and pleasant things to happen to me in the future." The community sample was also more likely to agree with the statements, "I would not change the past even if I could" and "as I grow older things seem better than I thought they would be:"

Stage 2. Respondents were asked to rate their neighborhoods. Six reported being very satisfied and four were somewhat satisfied. Nearly 
all (11) indicated that their neighborhood was a good place for older people to live. No one had any firm plans to move.

Self-reported health status remained much the same. Six reported being in good health for their age, five thought their health to be fair and one felt it was poor.

When asked if there was anyone they could call on if they needed help, all of the respondents indicated that there was. These included relatives (5), friends (4), neighbors (2), and others (1). Similarly, ten indicated that there were people they could talk to about things that bothered them. These confidants included: relatives (4), friends (4), and clexgymen (2).

of the seven respondents with children, five had seen children the day before the interview. Three said that they spoke with children every day and two others saw them each week. One saw her son less than once a year and for one it was uncertain (probably every three or four months). Only one of the seven indicated she was dissatisfied with relations with her children. Others were somewhat (1) or very satisfied (5) with these relationships.

There were differences between the sample regarding visiting with friends. The community sample was more likely to have seen friends within the week prior to the interview (9 compared to 5), and only one person (compared to 3) had not seen friends in more than a year. Visiting patterns with relatives were more similar to nursing home respondents, although the community sample seemed to visit more often. Almost all of the respondents indicated that they were very satisfied with relationships with both friends and relatives. 
HYPOTHESIS I

\section{Statistical Analysis}

The major hypothesis for this study was that institutionalized individuals who experience decreases in the amount and kind of interaction with friends and family will have less positive self-concepts than those who live in their own homes and/or maintain these relationships.

In order to determine whether social participation remained stable over time, Pearson correlations were computed using composite variables measuring social participation at stage 1 and Stage 2. The variable measuring social participation at stage 1 was made up of the following eight items: having, living with, and interaction with children; number of confidants; and the last time the respondent spoke with a friend, neighbor, relative, or other person. The variable measuring social participation at Stage 2 was also made up of eight items: number of children, the last time the respondent spoke with children, relatives, and friends; how often $s /$ he spoke with and visited children; and two items concerning presence of confidants. The correlation between the two composite variables was $.29(p=.086)$. The correlation suggests that overall there was some stability in social contact between Stage 1 and Stage 2. However, when the two groups were examined separately, the correlation for the institutionalized group was smaller than the correlation of the community group. Neither correlation was statistically significant.

Because the social interaction measures used at stage 2 had been modified and different from those used at Stage 1 , one must view these correlations with caution. To check further for these relationships, 
correlations.. were computed for single item variables that were very similar from stage 1 to stage 2. These are listed in Table III. For both samples, there was a strong correlation between stage 1 and Stage 2 of speaking with relatives. For the community group, there was a perfect correlation of those who responded to the question concerning the last time they had spoken with children. There was no significant correlation for the institutionalized group.

TABLE III

CORRELATIONS FOR SINGLE ITEM VARIABLES

FROM STAGE 1 TO STAGE 2

\begin{tabular}{|c|c|c|}
\hline Last time spoke with child & $\begin{array}{c}.1615 \\
(n=8)\end{array}$ & $\begin{array}{c}1.00 \\
(n=6)\end{array}$ \\
\hline Last time spoke with friend & $\begin{array}{r}-.1520 \\
(n=10)\end{array}$ & $\begin{array}{c}.1336 \\
(n=11)\end{array}$ \\
\hline Last time spoke with relative & $\begin{array}{c}.5149^{a} \\
(n=11)\end{array}$ \\
$(n=12)$
\end{tabular}

$a_{p}=.053$

${ }^{*} \mathrm{p}=.027$

In addition to determining the stability of social participation over time, it was important to identify similarities and differences between the institutionalized and community samples in the amount of social contact or participation experienced. This was done through analysis of variance. There were no significant differences between the samples at stage 1 or stage 2 in social contacts as measured by the composite social contact variables. Similarly, in examining differences 
in the single item social participation variables, only one of the tests revealed statistically significant differences. Community respondents spoke with friends more frequently than institutionalized respondents at stage $2(F(1,22)=5.22, \mathrm{p}=.016)$.

The above findings suggest that the study sample groups of institutionalized and community residing individuals were similar in terms. of amount and kind of social participation. Social contact alone, as measured in this study, therefore, does not appear to be associated with institutionalization.

Interpretation of Tennessee Self Concept Scores. The next phase of analysis involved examining and comparing the TSCS scores. The profile of the sample self-concept scores are presented in Figure 2. As seen in Figure 2 and Table $\mathrm{N}$. there were very few differences between the mean self-concepts of the nursing home and community groups, and an analysis of variance of all scores showed no statistical significance. However, both groups revealed significant differences from the TSCS norm groups, whose scores are included in Table $1 . \mathrm{V}$. Interpretation of these scores indicates that although the total self-concept score shows a positive overall self-concept, the selfcriticism score shows a tendency toward defensiveness, or a denial of negative attributes that most people generally accept about themselves (e.g., "once in a while I put off until tomorrow what I ought to do today"). High net and total conflict scores indicate a tendency to agree (or strongly agree) to statements suggesting positive attributes, rather than to reject negative attributes. Responses to positive items were also inconsistent with responses to similar items negatively worded in areas of self-perception, again with a tendency to overaffirm positive 


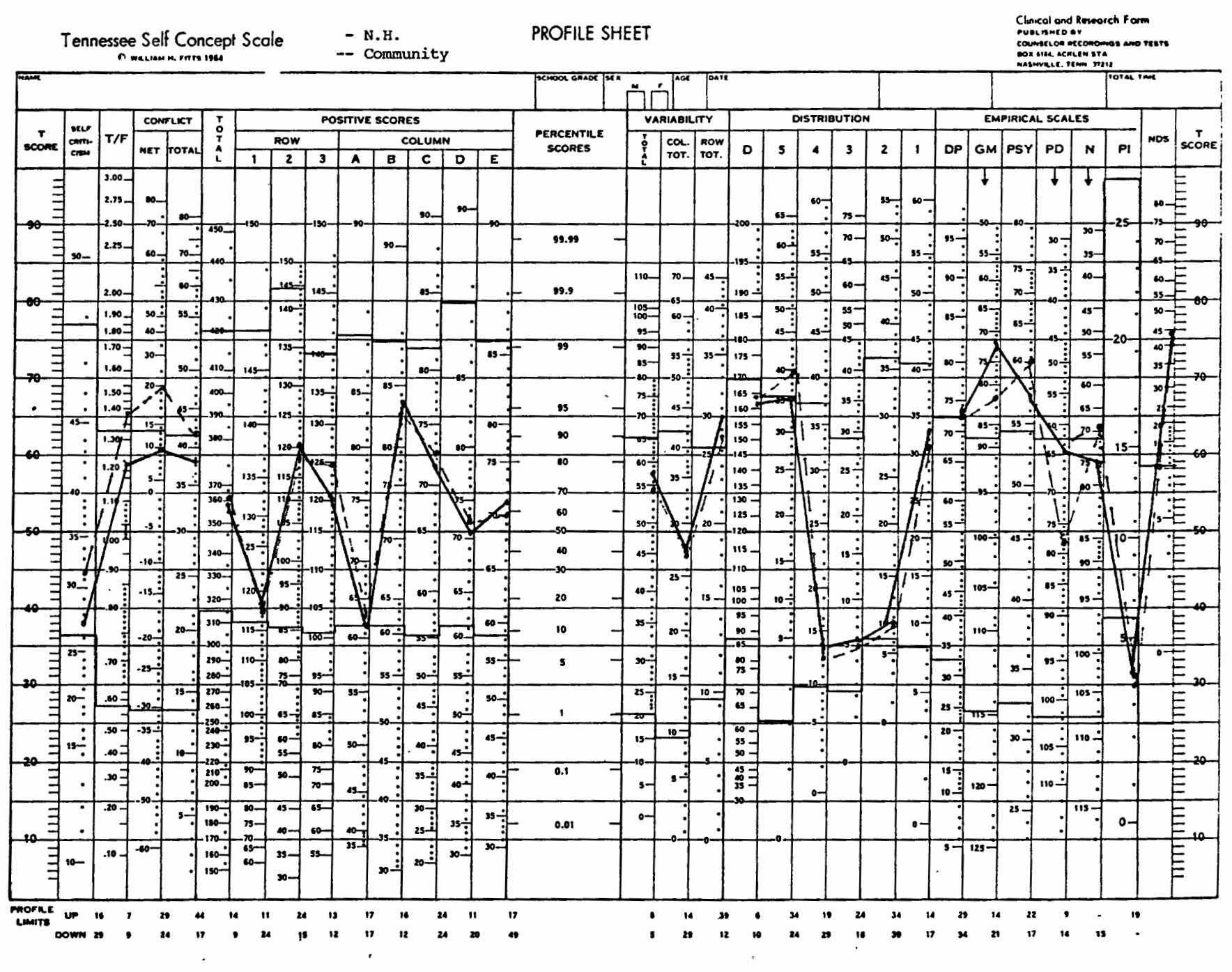

Figure 2. Profile of Self-Concept Scores 
TABLE IV

TENNESSEE SELF-CONCEPT MEAN SCORES

AND STANDARD DEVIATIONS

\begin{tabular}{|c|c|c|c|}
\hline & NURSING HOME & COMMUNITY & NORM GROUP \\
\hline True/false ratio & $\begin{array}{l}1.22 \\
(.41) * \\
\end{array}$ & $\begin{array}{l}1.40 \\
(.48) * *\end{array}$ & $\begin{array}{l}1.03 \\
(.29) \\
\end{array}$ \\
\hline Self-criticism & $\begin{array}{l}27.83 \\
(9.34) *\end{array}$ & $\begin{array}{l}31.92 \\
(9.01)\end{array}$ & $\begin{array}{l}35.54 \\
(6.70) \\
\end{array}$ \\
\hline Net conflict & $\begin{array}{c}9.67 \\
(21.56) * * \\
\end{array}$ & $\begin{array}{l}19.17 \\
(26.62) * * \\
\end{array}$ & $\begin{array}{l}-4.91 \\
(13.01) \\
\end{array}$ \\
\hline Total conflict & $\begin{array}{c}38.33 \\
(12.08) *\end{array}$ & $\begin{array}{c}42.67 \\
(15.52) * * \\
\end{array}$ & $\begin{array}{l}30.10 \\
(8.21)\end{array}$ \\
\hline Total self-concept & $\begin{array}{l}359.33 \\
(36.38)\end{array}$ & $\begin{array}{l}360.50 \\
(32.02) \\
\end{array}$ & $\begin{array}{l}345.57 \\
(30.70) \\
\end{array}$ \\
\hline $\begin{aligned} \text { Row } 1 & \\
& \text { (Identity) }\end{aligned}$ & $\begin{array}{l}118.50 \\
(12.29)\end{array}$ & $\begin{array}{l}117.58 \\
(14.74) *\end{array}$ & $\begin{array}{r}127.10 \\
(9.96) \\
\end{array}$ \\
\hline $\begin{array}{r}\text { Row } 2 \text { (Self-satisfaction) } \\
\end{array}$ & $\begin{array}{l}120.50 \\
(17.33) \\
\end{array}$ & $\begin{array}{l}118.42 \\
(14.18)\end{array}$ & $\begin{array}{l}103.67 \\
(13.79)\end{array}$ \\
\hline $\begin{array}{r}\text { Row } 3 \\
\text { (Behavior) }\end{array}$ & $\begin{array}{l}120.33 \\
(10.26) \\
\end{array}$ & $\begin{array}{r}124.50 \\
(8.68) \\
\end{array}$ & $\begin{array}{l}115.01 \\
(11.22)\end{array}$ \\
\hline $\begin{array}{l}\text { Collumn A } \\
\text { (Physical self) }\end{array}$ & $\begin{array}{c}62.58 \\
(11.94) * *\end{array}$ & $\begin{array}{l}63.25 \\
(10.25) \\
\end{array}$ & $\begin{array}{l}71.78 \\
(7.67) \\
\end{array}$ \\
\hline $\begin{array}{l}\text { Column B } \\
\text { (Moral/ethical self) }\end{array}$ & $\begin{array}{l}83.42 \\
(5.26)^{a}\end{array}$ & $\begin{array}{l}82.75 \\
(4.00)^{a} \\
\end{array}$ & $\begin{array}{l}70.33 \\
(8.70)\end{array}$ \\
\hline $\begin{array}{l}\text { Column C } \\
\text { (Personal self) } \\
\end{array}$ & $\begin{array}{l}71.17 \\
(9.74) \\
\end{array}$ & $\begin{array}{l}72.17 \\
(5.81) \\
\end{array}$ & $\begin{array}{l}64.55 \\
(7.41) \\
\end{array}$ \\
\hline $\begin{array}{l}\text { Column D } \\
\text { (Family self) }\end{array}$ & $\begin{array}{l}70.92 \\
(11.81) *\end{array}$ & $\begin{array}{l}72.17 \\
(8.53) \\
\end{array}$ & $\begin{array}{l}70.83 \\
(8.43) \\
\end{array}$ \\
\hline $\begin{array}{l}\text { Column E } \\
\text { (Social self) }\end{array}$ & $\begin{array}{l}71.25 \\
(9.76) \\
\end{array}$ & $\begin{array}{l}70.17 \\
(11.09) *\end{array}$ & $\begin{array}{l}68.14 \\
(7.86) \\
\end{array}$ \\
\hline Total variability & $\begin{array}{l}57.67 \\
(16.40) \\
\end{array}$ & $\begin{array}{r}54.42 \\
(13.44) \\
\end{array}$ & $\begin{array}{c}48.53 \\
(12.42)^{-} \\
\end{array}$ \\
\hline
\end{tabular}

Note. The values in this table are means with standard deviations in parentheses. The significance levels are associated with the $F$ tests for differences in the variance of each older sample with the norm group variance:

$* \mathrm{p} \leq .05$

${ }^{* * \mathrm{p}} \leq .01$

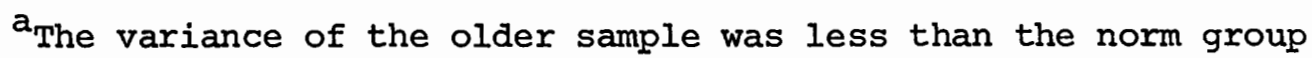
variance. 
attributes. This was more true for the community group, although the difference was not statistically significant. According to Fitts (1965), the high total conflict scores indicate confusion, contradiction and conflict in self-perception.

In examining the row and column scores, the row I or mean scores on identity ("What I am") and column A or mean scores on physical selfconcept were almost one standard deviation below the norm group. Most individuals were old and limited in their activities due to poor health, so the low score probably reflects the reality of the situation.

The family self-concept was nearly the same as for the norm group and the social self was only slightly higher. The remaining row and column means (self-satisfaction, behavior, moral/ethical self and personal self) from .47 to 1.44 above the norm group.

The pattern of variability for both groups was higher than the norm group suggesting that the self-concept varies from one area of self to another. In addition, these areas are not well integrated; some are viewed apart from the remainder of the self. At the same time most responses fell into the extreme categories of "completely true" and "completely false" indicating that the respondents possess a certainty about the way they view themselves.

In summary, the interpretation of the TSCS scores, based on the manual (Fitts, 1965) shows older people in this study to have generally positive self-concepts. At the same time, they appear to be defensive and inconsistent in their responses to the questions concerning themselves. Despite the inconsistency of responses, however, older people appear to respond with a high degree of certainty answering in the 
"completely false" or "completely true" categories.

These interpretations are based on directions provided by Fitts (1965) in the TSCS manual. However, these interpretations require further discussion. First, Although Fitts (1965) included old people in his norm group $(n=626)$, it was over represented by college students and people in the age brackets of 12-30. Thus, the deviant scores presented above may be the results of age differences in self-concept and therefore require more refined examination and interpretation.

This is supported by other studies examining older people which have found a pattern similar to the one reported in this study (see Table V) (Postema, 1970; Grant, 1966; Thompson, 1972). Thompson (1972) reviews these studies and compares them to studies with other age groups. He draws the following conclusions. First, standard deviations are generally much higher for older people than the norm group and studies with other age groups. This indicates that the elderly are a much more diverse and heterogeneous group in self-concept than the norm group or those in different age categories. This is consistent with the geıontological literature in other areas (Neugarten, 1973).

The standard deviations in this study are consistent with those discussed by Thompson (1972). For the nursing home groups, standard deviations were significantly greater than the noxm group in six of fourteen scores. These include the true/false ratio, self-criticism score, net conflict and total conflict scores, and the physical and family self-concept scores. There was a similar pattern for the community residing sample, with the addition of identity and the social selfconcept score being significantly greater than the norm group. The standard deviation for the moral/ethical self-concept in both groups 
TABLE V

MEANS AND STANDARD DEVIATIONS FOR

FOR SAMPLES OF ELDERLY PEOPLE

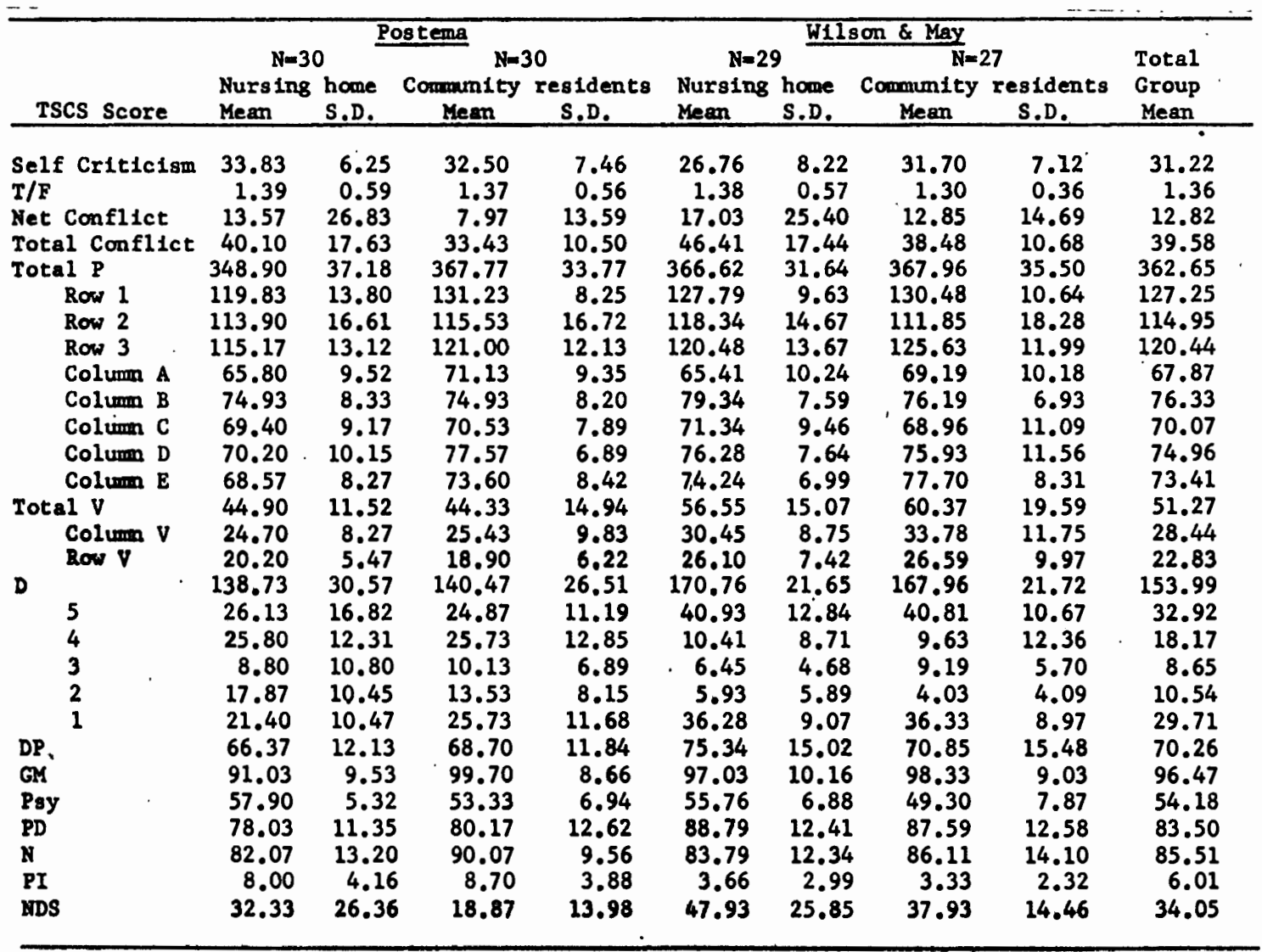

Note. From Warren Thompson, Correlates of the Self-Concept Counselor Recordings and Tests. Nashville, Tennessee, 1972:87. 
was significantly less than for the norm groups, indicating that the older people in this study have very similar views of themselves in this area.

In his second conclusion, Thompson (1972) suggests that "as the individual gets older, he comes to define himself in more definite terms and to be more decisive in his attempts at self-description" (p. 20). However, the generally high self-concept scores seem to be somewhat suspect because Thompson (1972) goes on to say that "elderly people appear to have less self-awareness, less capacity for self-criticism, and a much stronger set of defenses" (p. 22). Such statements warrant further examination and discussion and will be considered in the final chpater of this thesis.

Statistical analysis was used to clarify the relationship between the self-concept, social participation, and living situation. Pearson correlation coefficients were computed to determine the relationship between the self-concept scores and the social interaction measures. No significant correlations between self-concept scores and the composite social contact variables were found. However, there were correlations between some single item measures (see Table VI). The frequency with which respondents spoke with children and relatives was positively associated with total self-concept, identity, behavior, moral/ethical self, personal self, and social self.

These are important findings and support the assertion that selfconcept is related to social participation. None of the correlations were negative, which indicates an important pattern between the selfconcept and social contact. Contact with relatives appears to be most clearly associated with self-concept. These findings reflect a positive 
TABLE VI

PEARSON CORRELATION BETWEEN TENNESSEE

SELF-CONCEPT SCORES AND SOCIAL

PARTICIPATION AT STAGE 2

\begin{tabular}{|c|c|c|c|c|c|c|c|c|c|}
\hline & $\begin{array}{l}\text { Total } \\
\text { Self- } \\
\text { Concept }\end{array}$ & Identity & $\begin{array}{l}\text { Self } \\
\text { Satis- } \\
\text { faction }\end{array}$ & $\begin{array}{c}\text { Behavior } \\
\text { Self }\end{array}$ & $\begin{array}{c}\text { Physical } \\
\text { Self }\end{array}$ & $\begin{array}{l}\text { Moral- } \\
\text { Ethical } \\
\text { Self }\end{array}$ & $\begin{array}{c}\text { Personal } \\
\text { Self }\end{array}$ & $\begin{array}{l}\text { Family } \\
\text { Self }\end{array}$ & $\begin{array}{c}\text { Social } \\
\text { Self } \\
\end{array}$ \\
\hline $\begin{array}{l}\text { How often speak with } \\
\text { children }\end{array}$ & $\begin{array}{l}.26 \\
n=14\end{array}$ & $\begin{array}{l}.37 a \\
n=14\end{array}$ & $\begin{array}{l}.08 \\
n=14\end{array}$ & $\begin{array}{l}.22 \\
n=14\end{array}$ & $\begin{array}{l}.13 \\
n=14\end{array}$ & $\begin{array}{l}.02 \\
n=14\end{array}$ & $\begin{array}{l}.28 \\
n=14\end{array}$ & $\stackrel{.30}{n=14}$ & $\begin{array}{l}.25 \\
n=14\end{array}$ \\
\hline $\begin{array}{l}\text { How often visit with } \\
\text { children }\end{array}$ & $\begin{array}{l}.26 \\
\mathrm{n}=15\end{array}$ & $\begin{array}{l}.27 \\
n=15\end{array}$ & $\begin{array}{l}.30 \\
n=15\end{array}$ & $\begin{array}{l}.06 \\
n=15\end{array}$ & $\begin{array}{l}.20 \\
\mathrm{n}=15\end{array}$ & $\begin{array}{l}.06 \\
n=15\end{array}$ & $\begin{array}{l}.35^{a} \\
n=15\end{array}$ & $\stackrel{19}{n=15}$ & $\begin{array}{l}21 \\
\mathrm{n}=15\end{array}$ \\
\hline $\begin{array}{l}\text { How often speak with } \\
\text { relatives }\end{array}$ & $\begin{array}{l}.44 * \\
n=23\end{array}$ & $\begin{array}{l}: 38 * \\
n=23\end{array}$ & $\begin{array}{r}.31^{a} \\
n=23\end{array}$ & $\stackrel{.52 *}{n=23}$ & $\begin{array}{l}.4 I^{*} \\
\mathrm{n}=23\end{array}$ & $\stackrel{.37 *}{n=23}$ & $\begin{array}{l}.27^{a} \\
\mathrm{n}=23\end{array}$ & $\begin{array}{l}.25 \\
n=23\end{array}$ & $\begin{array}{l}.40^{*} \\
\mathrm{n}=23\end{array}$ \\
\hline $\begin{array}{l}\text { How often visit with } \\
\text { relatives }\end{array}$ & $\begin{array}{l}.38 * \\
n=23\end{array}$ & $\stackrel{.27^{a}}{n=23}$ & $\stackrel{.32^{a}}{n=23}$ & $\begin{array}{l}.44 * \\
\mathrm{n}=23\end{array}$ & $\stackrel{.31^{a}}{n=23}$ & $\begin{array}{c}.25 \\
n=23\end{array}$ & $\begin{array}{c}.22 \\
\mathrm{n}=23\end{array}$ & $\begin{array}{l}.20 \\
n=23\end{array}$ & $\begin{array}{l}.45 * \\
\mathrm{n}=23\end{array}$ \\
\hline $\begin{array}{l}\text { Last time spoke with } \\
\text { friends }\end{array}$ & $\begin{array}{l}.39 * \\
n=22\end{array}$ & $\begin{array}{l}.41 * \\
n=22\end{array}$ & $\begin{array}{l}.25 \\
n=22\end{array}$ & $\begin{array}{l}.39 * \\
n=22\end{array}$ & $\begin{array}{l}.28^{a} \\
n=22\end{array}$ & $\begin{array}{l}.37 * \\
n=22\end{array}$ & $\begin{array}{l}.26 \\
n=22\end{array}$ & $\begin{array}{l}.15 \\
n=22\end{array}$ & $\begin{array}{l}.48 * \\
n=22\end{array}$ \\
\hline $\begin{array}{l}\text { How often speak with } \\
\text { friends }\end{array}$ & $\begin{array}{l}.19 \\
n=21\end{array}$ & $\begin{array}{l}.25 \\
n=21\end{array}$ & $\begin{array}{l}.02 \\
n=21\end{array}$ & $\begin{array}{l}.25 \\
n=21\end{array}$ & $\begin{array}{l}.03 \\
n=21\end{array}$ & $\begin{array}{l}.33^{a} \\
n=21\end{array}$ & $\begin{array}{l}.04 \\
n=21\end{array}$ & $\begin{array}{l}.03 \\
\mathrm{n}=21\end{array}$ & $\begin{array}{l}.38 * \\
n=21\end{array}$ \\
\hline $\begin{array}{l}\text { How often visit with } \\
\text { friends }\end{array}$ & $\begin{array}{l}.21 \\
n=21\end{array}$ & $\begin{array}{l}.27 \\
n=21\end{array}$ & $\begin{array}{l}.04 \\
n=21\end{array}$ & $\begin{array}{l}.30^{a} \\
n=21\end{array}$ & $\begin{array}{c}.21 \\
n=21\end{array}$ & $\begin{array}{l}.30^{a} \\
n=21\end{array}$ & $\begin{array}{l}.02 \\
n=21\end{array}$ & $\begin{array}{l}.04 \\
n=21\end{array}$ & $\begin{array}{l}.36 * \\
n=21\end{array}$ \\
\hline
\end{tabular}

${ }^{*} \mathrm{p} \leq .05$

$a_{p} \leq 10$ 
relationship between the way older persons in this study view themselves and the frequency with which they interact with relatives.

Fewer correlations between interaction with children and self-concept were statistically significant which may be due to the small number of respondents with children.

There was a significant correlation between when the respondents last spoke with friends and total self-concept $(x=.39)$ and identity $(r=.41)$. This supports much of the gerontological literature which suggests that peer groups are important in determining how individuals view themselves (Blau, 1973).

In order to clarify relationships further, six stepwise multiple regression analyses were used. While the sample size for this type of analysis is small, it was felt that the multiple regression would detect patterns which could then be examined in more depth in future studies. Self-concept scores (total self-concept and the row and column scores) were the dependent variables with living situation and the social contact variables as predictors. Separate analyses were done using stage 1 and stage 2 social contact variables as the second predictor. A third predictor was constructed by multiplying living situation by social participation, a variable reflecting an interaction between living situation and social participation. This variable was used to help determine whether or not living situation and social participation interact to produce an additional effect on self-concept.

The regression analysis did not yield significant findings. Neither living situation, social participation, as measured by these variables, nor the interaction variable appear to be useful predictors of the self-concept. It is interesting to note that in all six of the 
stepwise regression analyses, the interaction variable was entered into the equation first, followed by living situation, and finally social participation. The sample size was small, and as a result, findings must be viewed cautiously and there needs to be more study before definitive conclusions can be drawn. However, the ordering of the variables suggest that there may be some interaction effect that could be explored in future studies.

The data analysis presented above is clearly the result of an exploratory study. The sample size is too small to allow one to draw conclusions. However, from the data analysis, patterns of responses and interpretations of the TSCS, several important questions were raised. First, were measures of social contact adequate and useful? Second, what other variables are associated with positive or negative self-concept scores? Finally, what is the nature of the self-concept in old age? In order to explore these questions, case studies of the respondents were examined. Implications from these qualitative data are presented in the following section.

Qualitative Analysis of Case Studies

The 24 case studies are summarized in Figure 3. (The complete case studies are presented in Appendix V.) Information presented in the summaries includes living situation, self-concept, positive and negative aspects of social support, well-being indicator scores, self-rated health, personal control, and unique characteristics. The self-concept description is derived from the TSCS scores. The standard deviation from the sample mean $(n=24)$ for the total selfconcept is given, as are the areas of self-concept which fall above or 


\begin{tabular}{|c|c|c|c|c|c|}
\hline \begin{tabular}{|c} 
Hame and $n g e$ \\
(Stage 1,1975$)$ \\
\end{tabular} & $\begin{array}{l}\text { Living situation } \\
\text { (stage } 2, \text {, 1977) } \\
\text { Satisfaction } \\
\end{array}$ & $\begin{array}{c}\text { sclf-Concept } \\
\text { Stage 2 }\end{array}$ & Positive Ajpects & $\begin{array}{l}\text { Soc1al Supports - Stage } 2 \\
\text { Nogative nspects }\end{array}$ & $\begin{array}{c}\text { Change } \\
\text { (stage 2-stage 2) }\end{array}$ \\
\hline $\begin{array}{l}\text { HRS. GOODMNN } \\
79 \text { years }\end{array}$ & $\begin{array}{l}\text { - nursing honc } \\
\text { expressed dissa sfaction } \\
\text { with nursing hone--felt } \\
\text { 1 solated from other } \\
\text { residents; expressed } \\
\text { fears about moving }\end{array}$ & $\begin{array}{l}\text { - very low total gelf- } \\
\text { concept score }(-2.47 \\
\text { sD below mean) } \\
\text { - low in all areas, parti- } \\
\text { cularly identity, } \\
\text { physical, family, and } \\
\text { social self } \\
\text { - las self-criticism } \\
\text { - inconsistency in response }\end{array}$ & $\begin{array}{l}\text { - focis close to daughter- } \\
\text { in-law \& sces her fre- } \\
\text { quently (daughter-in- } \\
\text { law is widow of irs. } \\
\text { coodman's favorite } \\
\text { child \& lives out of } \\
\text { state) }\end{array}$ & $\begin{array}{l}\text { - widow for many years } \\
\text { 3 children in metrogoli- } \\
\text { tan area-has poor } \\
\text { relationships with all } \\
\text { - has not maintained rela- } \\
\text { tionships with friends } \\
\text { - expressions of hurt, } \\
\text { bitterness, distrust } \\
\text { - uncertain how low } \\
\text { daughter-in-law will be } \\
\text { in area }\end{array}$ & $\begin{array}{l}\text { - sees children same } \\
\text { (infrequenty) } \\
\text { - decline in contact with } \\
\text { friends } \\
\text { - increase contact (tempo- } \\
\text { rarily) with daughter- } \\
\text { in-law }\end{array}$ \\
\hline & & $\begin{array}{l}\text { Other Well-Being Indicators } \\
\text { and Standard Deviation } \\
\text { from Sample Mean (Stage 1) }\end{array}$ & Self-Rated Health & Unique Characteristics & $\begin{array}{c}\text { Control Over Life Events } \\
\text { (Stage 2) }\end{array}$ \\
\hline & & $\begin{array}{c}\text { - activity slightly below } \\
\text { mean (-.29) } \\
\text { - low medical status }(-.98) \\
\text { daily functioning high } \\
\text { (.49) } \\
\text { - cognitive status similar } \\
\text { to sample (.23) } \\
\text { - low housing scare }(-.81) \\
\text { very low income }(-2.05) \\
\text { - very low life satisfac- } \\
\text { tion (-1.46) } \\
\text { high social contact (.54) }\end{array}$ & $\begin{array}{l}\text { Stage } 1-\text { poor } \\
\text { Stage } 2 \text { - poor }\end{array}$ & $\begin{array}{l}\text { - very willing to be inter- } \\
\text { viewed \& talk about } \\
\text { problems with chilören } \\
\text { - ambulatory \& takes care } \\
\text { of much of her own care } \\
\text { - talks at length of poor } \\
\text { health in spite of } \\
\text { ability to function } \\
\text { well }\end{array}$ & $\begin{array}{l}\text { - says she cannot solve her } \\
\text { problems quite easily } \\
\text { - says she cannot take care } \\
\text { of herself in all } \\
\text { situations } \\
\text { - 1ittle control of nursing } \\
\text { home placement } \\
\text { - fearful of what "they" } \\
\text { will do to her }\end{array}$ \\
\hline \begin{tabular}{|l} 
Name and Age \\
(Stage 1, 1975)
\end{tabular} & $\begin{array}{c}\text { Living Situation } \\
\text { (Stage 2, 1977) } \\
\text { Satisfaction } \\
\end{array}$ & $\begin{array}{l}\text { Self-Concept } \\
\text { Stage } 2\end{array}$ & \multicolumn{3}{|c|}{$\begin{array}{c}\text { Social Supports - Stage } 2 \\
\text { Negative Aspects }\end{array}$} \\
\hline $\begin{array}{l}\text { MRS. TODD } \\
66 \text { years }\end{array}$ & $\begin{array}{l}\text { community } \\
\text { very satisfied with } \\
\text { neighborhood; it is } \\
\text { "quiet and } \\
\text { respectable" }\end{array}$ & \begin{tabular}{|} 
- very low total self- \\
concept (-2.00 standard \\
deviations below mean) \\
- low in all areas, par- \\
ticularly physical, \\
family, social self \\
- high self-criticism \\
inconsistency in \\
response
\end{tabular} & \begin{tabular}{|l} 
- lives with mother \\
(age 92 ) \\
- recent visit from rela- \\
tives from california
\end{tabular} & \begin{tabular}{|l} 
- widow \\
: no children \\
: no condidante \\
many negative conments \\
about friends, rela- \\
tives \\
- dissatisfied with rela- \\
tionships; much anger \\
- sees relatives infre- \\
quently (less than \\
yearly) \\
sees friends infre- \\
quently (evezy 6 months)
\end{tabular} & $\begin{array}{l}\text { - little change; except } \\
\text { had seen relatives } \\
\text { recently }\end{array}$ \\
\hline & & $\begin{array}{l}\text { other Well-Being Indicators } \\
\text { and Standard Deviation } \\
\text { from Sample Mean (Stage 1) }\end{array}$ & Self-Rated Health & Unique Characteristics & $\begin{array}{c}\text { Control Over Life Events } \\
\text { (Stage 2) }\end{array}$ \\
\hline $\begin{array}{l}\text { of́ Case } \\
\text { study sa }\end{array}$ & np & \begin{tabular}{|c|} 
- low activity $(-1.77)$ \\
- low daily functioning \\
$\quad(-.24)$ \\
- low medical status $(-1.17)$ \\
- fairly high cognitive \\
status (.26) \\
- high housing score $(1.37)$ \\
fairly low income $(-.34)$ \\
- life satisfaction low \\
$(-1.09)$ \\
- low social contact \\
$(-1.98)$
\end{tabular} & $\begin{array}{l}\text { Stage } 1 \text { - fair } \\
\text { Stage } 2 \text { - poor }\end{array}$ & $\begin{array}{l}\text { - proud of mind and per- } \\
\text { severance } \\
\text { - well-read } \\
\text { housebound } \\
\text { - very willing to be } \\
\text { interviewed } \\
\text { : seems very independent } \\
\text { seems very bitter } \\
\text { "To get through life you } \\
\text { need a strong mind } \\
\text { and strong guts" }\end{array}$ & $\begin{array}{l}\text { - says she cannot take } \\
\text { care of herself in } \\
\text { all situations } \\
\text { - says she solves her } \\
\text { problems quite } \\
\text { easily } \\
\text { - is controlling work } \\
\text { being done on home } \\
\text { by withholding pay- } \\
\text { ment until the job } \\
\text { is done to her } \\
\text { satisfaction }\end{array}$ \\
\hline
\end{tabular}




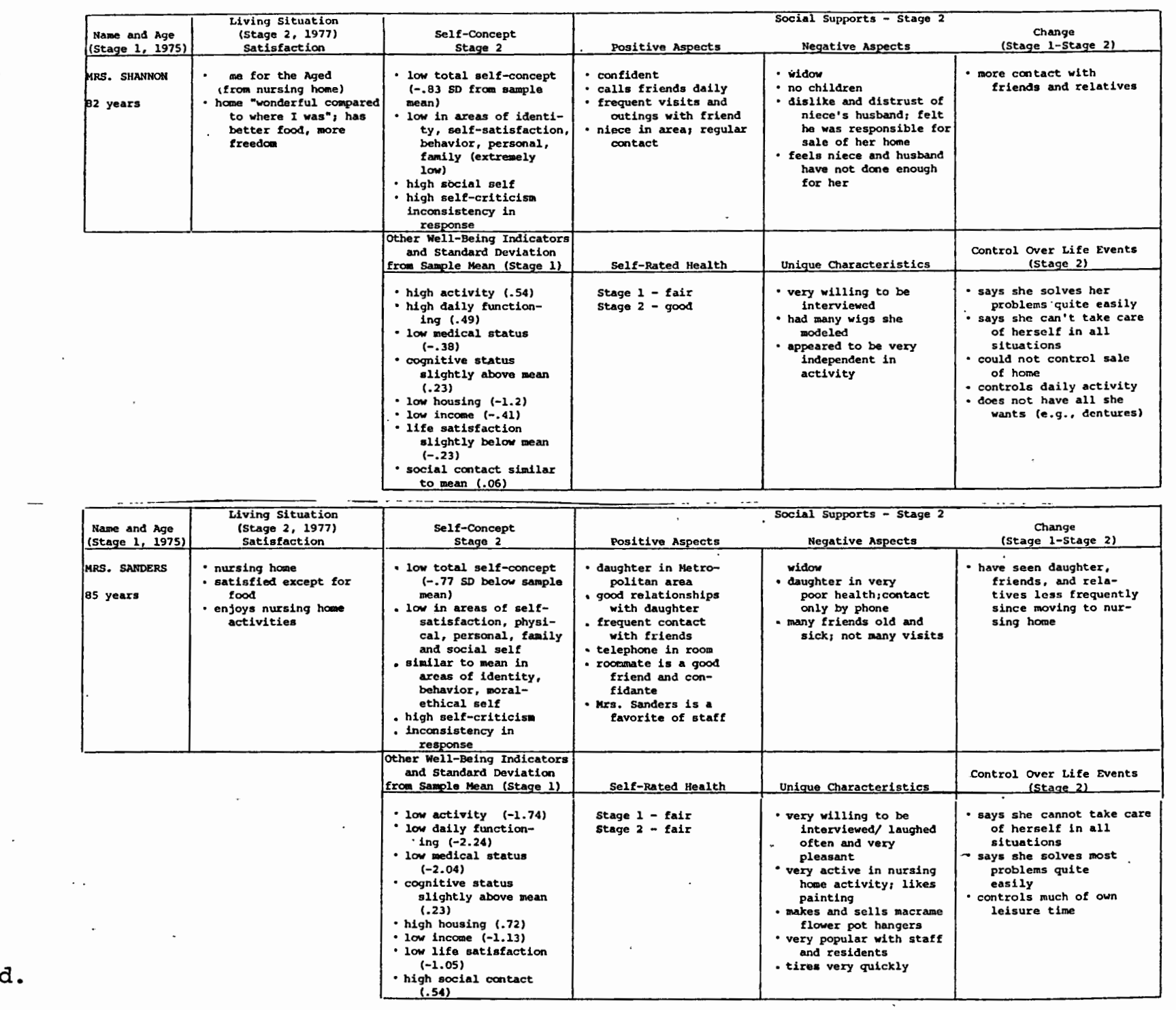




\begin{tabular}{|c|c|c|c|c|c|}
\hline $\begin{array}{r}\text { Llame and } n g e \\
\text { (stage } 1,1975) \\
\end{array}$ & $\begin{array}{l}\text { 2iving stivation } \\
\text { (stage } 2,1977) \\
\text { satisfaction } \\
\end{array}$ & $\begin{array}{c}\text { Se1f-Concept } \\
\text { Stage } 2 \\
\end{array}$ & Positive Aspects & $\begin{array}{l}\text { Soc1al Supports - stage 2 } \\
\text { Negative Aspects } \\
\end{array}$ & $\begin{array}{l}\text { Change } \\
\text { (stage } 1 \text {-stage 2) } \\
\end{array}$ \\
\hline \multirow[t]{3}{*}{$\begin{array}{l}\text { MRS. GROCAN } \\
78 \text { yeare }\end{array}$} & $\begin{array}{l}\text { : communlty } \\
\text { neighborhood good place } \\
\text { to live } \\
\text { - very satisfied, but wish } \\
\text { there was grocery stare } \\
\text { to replace one that } \\
\text { burned dowm }\end{array}$ & 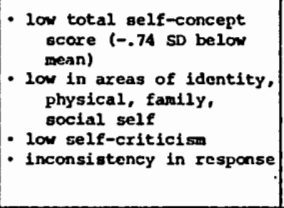 & $\begin{array}{l}\text { - frequent contact with } \\
\text { daughter } \\
\text { fond of grandsons }\end{array}$ & 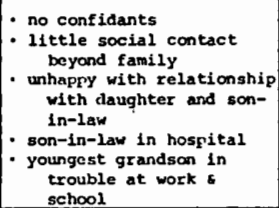 & $\begin{array}{l}\text { - daughter lives farther } \\
\text { away but no change in } \\
\text { frequency of contact } \\
\text { - fricnd ill, but amount of } \\
\text { contact same }\end{array}$ \\
\hline & & $\begin{array}{l}\text { Other Well-Being Indicators } \\
\text { and standard Deviation } \\
\text { Iron sample thean (Stage 1) } \\
\end{array}$ & Self-Rated Health & Unique Characteristics & $\begin{array}{c}\text { Control } \begin{array}{l}\text { ver Life Events } \\
\text { (Stage 2) }\end{array} \\
\end{array}$ \\
\hline & & 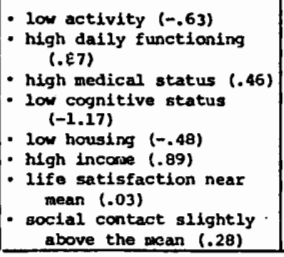 & $\begin{array}{l}\text { stagge } 1=\text { good } \\
\text { stage } 2 \text { - faitr }\end{array}$ & $\begin{array}{l}\text { - very willing to be } \\
\text { interviewed } \\
\text { wanted to talk about } \\
\text { problens with daughter } \\
\text { \& family } \\
\text { has of ten helped out } \\
\text { daughter } \& \text { grand- } \\
\text { children with money }\end{array}$ & $\begin{array}{l}\text { - says she solves her prob- } \\
\text { lens easily } \\
\text { says she can take care of } \\
\text { herself in any } \\
\text { situation. } \\
\text { controls own noney and } \\
\text { activity }\end{array}$ \\
\hline
\end{tabular}

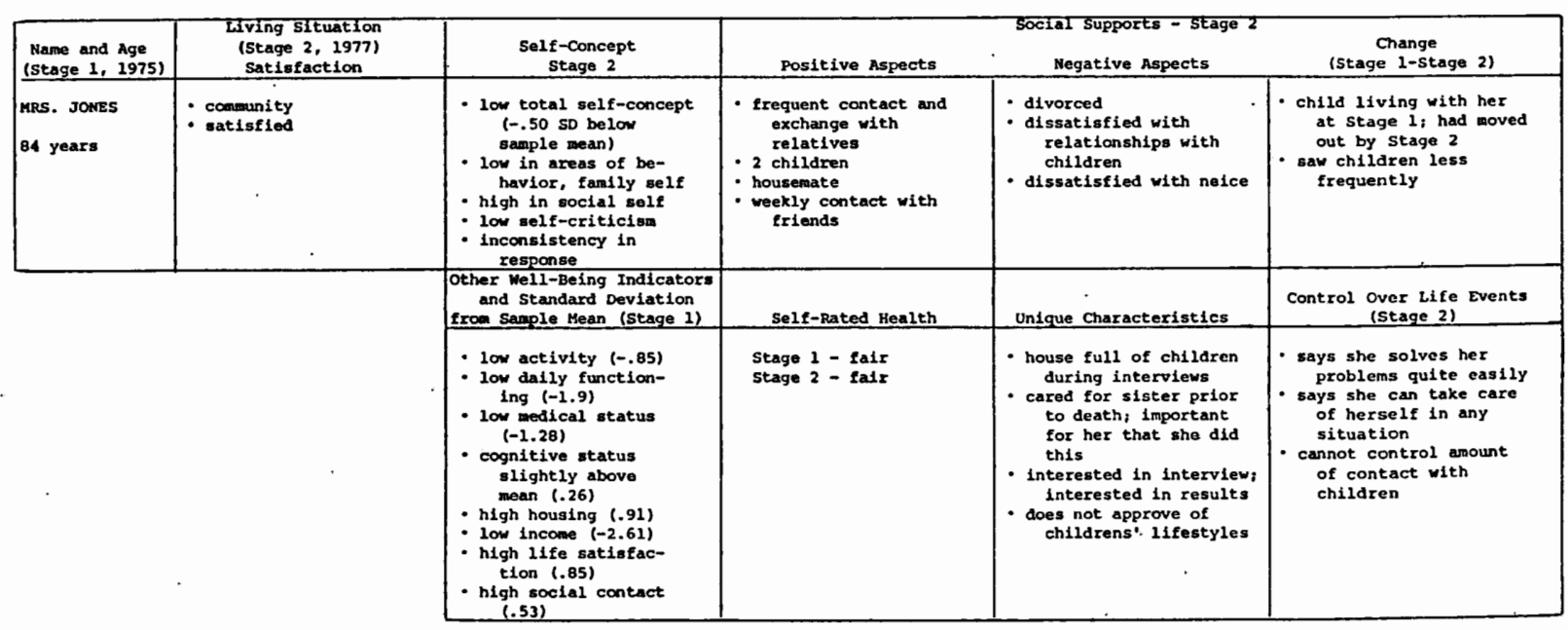




\begin{tabular}{|c|c|c|c|c|c|}
\hline $\begin{array}{l}\text { thame and Age } \\
\text { (Stage 1, 1975) } \\
\end{array}$ & $\begin{array}{l}\text { Living Situation } \\
\text { (Stage } 2,1977) \\
\text { Satisfaction } \\
\end{array}$ & $\begin{array}{c}\text { Self-Concept } \\
\text { Stage } 2\end{array}$ & Positive Aspects & $\begin{array}{l}\text { Social Supports - stage } 2 \\
\text { legative Aspects }\end{array}$ & $\begin{array}{c}\text { Change } \\
\text { (stage 1-stage 2) }\end{array}$ \\
\hline \multirow[t]{3}{*}{$\begin{array}{l}\text { MR. HAFKIIIS } \\
73 \text { years }\end{array}$} & $\begin{array}{l}\text { nursing home } \\
\text { says he hates the nursing } \\
\text { home and "would kill a } \\
\text { gan to get out" }\end{array}$ & $\begin{array}{l}\text { - Low total self-concept } \\
\text { (-.So sD below the mean) } \\
\text { low in areas of behavior, } \\
\text { personal and social self } \\
\text { - high self-criticisn } \\
\text { inconsistency in response } \\
\text { to positive and negative } \\
\text { itens } \\
\text { consistency from one area } \\
\text { of self-perception to } \\
\text { another }\end{array}$ & $\begin{array}{l}\text { - talks of support from } \\
\text { wife } \\
\text { sces children (two) } \\
\text { frequently }\end{array}$ & $\begin{array}{l}\text { - divorced or separated } \\
\text { - wife or ex-wife } 111 \\
\text { children are retarded }\end{array}$ & $\begin{array}{l}\text { sees children nore often } \\
\text { sees friends less often } \\
\text { sees relatives more often } \\
\text { (saw sister one time) }\end{array}$ \\
\hline & & $\begin{array}{l}\text { Other Well-Being Indicators } \\
\text { and Standard Deviation } \\
\text { fran Sarple Hean (Stage 1) }\end{array}$ & Self-Rated Health & Unique Chaxacteristics & $\begin{array}{c}\text { Control Over Life Events } \\
\text { (Stage 2) }\end{array}$ \\
\hline & & $\begin{array}{l}\text { Low activity }(-1.12) \\
\text { low daily functioning } \\
\quad(-1.33) \\
\text { low medical status }(-.38) \\
\text { hight cognitive status } \\
\quad(.94) \\
\text { low housing }(-1.58) \\
\text { high incone (.55) } \\
\text { - life satisfaction near } \\
\text { pean (.18) } \\
\text { high social contact (.79) }\end{array}$ & $\begin{array}{l}\text { Stage } 1-\text { good } \\
\text { Stage } 2-\text { good }\end{array}$ & $\begin{array}{l}\text { very willing to be inter- } \\
\text { viewed; difficult to } \\
\text { understand } \\
\text { cognitive status seemed } \\
\text { quite low } \\
\text { pany stage } 1 \text { scores } \\
\text { (income, cognitive, } \\
\text { social) seem inconsis- } \\
\text { tent with stage } 1 \\
\text { interviewer coments }\end{array}$ & $\begin{array}{c}\text { says he solves his } \\
\text { problems quite easily } \\
\text { says he can take care of } \\
\text { himself in any situation }\end{array}$ \\
\hline $\begin{array}{l}\text { Name and Age } \\
\text { (Stage 1, 1975) } \\
\end{array}$ & $\begin{array}{l}\text { Living Situation } \\
\text { (stage } 2,1977 \text { ) } \\
\text { Satisfaction } \\
\end{array}$ & $\begin{array}{c}\text { Self-Concept } \\
\text { Stage 2 }\end{array}$ & \multicolumn{3}{|c|}{ Social Supports - stage 2} \\
\hline $\begin{array}{l}\text { MRS. BISHOP } \\
67 \text { years }\end{array}$ & $\begin{array}{l}\text { community } \\
\text { somewhat satisfied with } \\
\text { neighborhood; "good } \\
\text { place for old people } \\
\text { to live" }\end{array}$ & $\begin{array}{l}\text { high total self-concept } \\
\text { (.42 SD above sample } \\
\text { mean) } \\
\text { high in areas of identity, } \\
\text { physical, farily, social } \\
\text { self } \\
\text { high self-criticism } \\
\text { inconsistency in response }\end{array}$ & $\begin{array}{l}\text { married } \\
\text { many tenants are friends, } \\
\text { frequent contact } \\
\text { active in senior center }\end{array}$ & & \\
\hline & & $\begin{array}{l}\text { Othex well-Being Indicators } \\
\text { and Standard Deviation } \\
\text { froa Sample Hean (Stage 1) }\end{array}$ & Self-Rated Health & Unique Chaxacteristics & $\begin{array}{c}\text { Control Over Life Events } \\
\text { (Stage 2) }\end{array}$ \\
\hline - & . & $\begin{array}{l}\text { mean activity }(.06) \\
\text { high daily functioning } \\
\text { (.87) } \\
\text { mean pedical status (.09) } \\
\text { high cognitive status }(.96) \\
\text { mean income }(.07) \\
\text { high life satisfaction } \\
\text { (1.90) } \\
\text { high social contact (.53) }\end{array}$ & $\begin{array}{l}\text { Stage } 1 \text { - good } \\
\text { stage } 2 \text { - good }\end{array}$ & $\begin{array}{l}\text { apartment nanager } \\
\text { a lot of nervous energy } \\
\text { very interested in } \\
\text { interview }\end{array}$ & $\begin{array}{l}\text { - says she solves most } \\
\text { problems quite easily } \\
\text { - says she can take care of } \\
\text { herself in any situation } \\
\text { - difficulty finding help } \\
\text { for apartment } \\
\text { - she is working }\end{array}$ \\
\hline
\end{tabular}




\begin{tabular}{|c|c|c|c|c|c|}
\hline $\begin{array}{l}\text { Name and Age } \\
\text { (Stage 1, 1975) } \\
\end{array}$ & $\begin{array}{l}\text { Living situation } \\
\text { (stage 2, 1977) } \\
\text { Satisfaction }\end{array}$ & $\begin{array}{c}\text { Self-Concept } \\
\text { Stage } 2\end{array}$ & \multicolumn{3}{|c|}{$\begin{array}{c}\text { Social Supports - stage 2 } \\
\text { Change } \\
\text { Negative Aspects } \\
\text { (Stage 1-Stage 2) }\end{array}$} \\
\hline $\begin{array}{l}\text { SIR. PORTER } \\
83 \text { years }\end{array}$ & $\begin{array}{l}\text { conmunity } \\
\text { very satisfied with } \\
\text { neighborhood; "good, } \\
\text { clean, decent people } \\
\text { live here" }\end{array}$ & $\begin{array}{l}\text { - high total self concept } \\
\text { (.60 sD above sample } \\
\text { rean) } \\
\text { high in areas of } \\
\text { Identity, self- } \\
\text { satisfaction, physical } \\
\text { and fauily self } \\
\text { low in social self } \\
\text { high self-criticism } \\
\text { sone inconsistency in } \\
\text { response }\end{array}$ & $\begin{array}{l}\text { narried } \\
\text { 1ive with daughter } \\
\text { three children } \\
\text { expressions of mutual } \\
\because \text { enjoyment in relation- } \\
\text { ships with children } \\
\text { confidants } \\
\text {. }\end{array}$ & & . \\
\hline & & $\begin{array}{l}\text { Other well-peing Indicators } \\
\text { and standard Deviation } \\
\text { from Sarple Hean (Stage i) }\end{array}$ & Self-Rated Health & Unique Characteristics & $\begin{array}{c}\text { Control Over Life Events } \\
\text { (Stage 2) }\end{array}$ \\
\hline . & & $\begin{array}{l}\text { - activity slightly below } \\
\text { nean (-.38) } \\
\text { - daily functioning slight- } \\
\text { ly below mean (-.24) } \\
\text { - high nedical status (.46) } \\
\text { - high cognitive status } \\
\text { (.96) } \\
\text { - high housing (1.37) } \\
\text { - incone slightly above } \\
\text { nean (.27) } \\
\text { - high life satisfaction } \\
\text { (1.52) }\end{array}$ & $\begin{array}{l}\text { Stage } 1-\text { good } \\
\text { Stage } 2-\text { good }\end{array}$ & $\begin{array}{l}\text { - very willing to be } \\
\text { interviewed } \\
\text { - very pleasant, did not } \\
\text { explain many answers } \\
\text { or go into much detail } \\
\text { - wife present }\end{array}$ & $\begin{array}{l}\text { says he solves his } \\
\text { problems yuite easily } \\
\text { says he can take care } \\
\text { of himself in most } \\
\text { situations } \\
\text { some dependence on wife } \\
\text { and daughter }\end{array}$ \\
\hline
\end{tabular}

\begin{tabular}{|c|c|c|c|c|c|}
\hline $\begin{array}{c}\text { Name and Age } \\
\text { (Stage 1, 1975) }\end{array}$ & $\begin{array}{c}\text { Living Situation } \\
\text { (stage } 2,1977 \text { ) } \\
\text { Satisfaction } \\
\end{array}$ & $\begin{array}{c}\text { Self-Concept } \\
\text { Stage 2 }\end{array}$ & Positive Aspects & $\begin{array}{l}\text { Social Supports - Stage } 2 \\
\text { Negative Aspects }\end{array}$ & $\begin{array}{c}\text { Change } \\
\text { (Stage 1-stage 2) } \\
\end{array}$ \\
\hline $\begin{array}{l}\text { URS. HILL } \\
81 \text { years }\end{array}$ & $\begin{array}{l}\text { community } \\
\text { neighborhood good place } \\
\text { to live } \\
\text { home close to church, } \\
\text { family, friends }\end{array}$ & $\begin{array}{l}\text { - high total self-concept } \\
\text { (.60 SD above sample } \\
\text { mean) } \\
\text { - above mean in self- } \\
\text { satisfaction, behavior, } \\
\text { noral-ethical, fanily, } \\
\text { social self } \\
\text { - high self-criticism } \\
\text { - consistency in response }\end{array}$ & $\begin{array}{l}\text {. two children in the area } \\
\text { two canfidants } \\
\text { several friends, } \\
\text { frequent contect } \\
\text { frieqds provide trans- } \\
\text { portation and have } \\
\text { helped modify hore } \\
\text { grandson purchases } \\
\text { groceries, etc. } \\
\text { church activities } \\
\text { inportant } \\
\end{array}$ & $\begin{array}{l}\text { - widow } \\
\text { one daughter has } \\
\text { arteriosclezosis }\end{array}$ & $\begin{array}{l}\text { amount and quality } \\
\text { appears to have stayed } \\
\text { the same; more depen- } \\
\text { dent due to decline } \\
\text { in health }\end{array}$ \\
\hline & & $\begin{array}{l}\text { other well-being Indicators } \\
\text { and Standard Deviation } \\
\text { from Sample Hean (Stage 1) }\end{array}$ & Self-Rated Health & Unique Characteristics & $\begin{array}{c}\text { Cantrol Over Life Events } \\
\text { (Stage 2) }\end{array}$ \\
\hline . & & $\begin{array}{l}\text { - activity slightly above } \\
\text { mean (.29) } \\
\text { - daily functioning slight- } \\
\text { ly below mean }(-.29) \\
\text { - high medical status (1.91) } \\
\text { - high cognitive status } \\
\text { (.96) } \\
\text { - high housing (.91) } \\
\text { - income below mean (-.34) } \\
\text { high life satisfaction } \\
\text { (..40) } \\
\text { - high social contact (.90) }\end{array}$ & $\begin{array}{l}\text { Stage } 1 \text { - good } \\
\text { stage } 2-\text { fair }\end{array}$ & $\begin{array}{l}\text { - very pleasant, interested } \\
\text { in interview } \\
\text { - does handwork to control } \\
\text { shaking from Parkin- } \\
\text { son's disease } \\
\text { - health deteriorated, } \\
\text { expects to need nursing } \\
\text { home in future } \\
\text { - well dressed } \\
\text { - planning trip to utah }\end{array}$ & $\begin{array}{l}\text { - solves some but not all } \\
\text { problems easily } \\
\text { says she can't take care } \\
\text { of herself in most } \\
\text { situations } \\
\text { - controls aspects of 1ife } \\
\text { (routine) with help } \\
\text { from friends and } \\
\text { family }\end{array}$ \\
\hline
\end{tabular}




\begin{tabular}{|c|c|c|c|c|c|}
\hline $\begin{array}{l}\text { Name and Age } \\
\text { (Stage } 1,1975)\end{array}$ & $\begin{array}{l}\text { Living Situation } \\
\text { (Stage } 2,1977 \text { ) } \\
\text { Satisfaction }\end{array}$ & $\begin{array}{l}\text { Self-Concept } \\
\text { Stage 2 }\end{array}$ & \multicolumn{3}{|c|}{$\begin{array}{cc}\text { Social supports - Stage 2 } & \begin{array}{c}\text { Change } \\
\text { Negative Aspects }\end{array} \\
\text { (Stage 1-Stage 2) } \\
\end{array}$} \\
\hline $\begin{array}{l}\text { MRS. ANDERSOI } \\
79 \text { years }\end{array}$ & $\begin{array}{l}\text { - nursing home } \\
\text { satisfied; "If I can't } \\
\text { go home I want to stay } \\
\text { here }\end{array}$ & $\begin{array}{l}\text { - high total self concept } \\
\text { (.66 sD above sample } \\
\text { mean) } \\
\text { - high in areas of self- } \\
\text { satisfaction, personal } \\
\text { and social self } \\
\text { - low self-criticism } \\
\text { - inconsistency in response } \\
\text { to positive and } \\
\text { negative itens } \\
\text { consistenty froo one area } \\
\text { of self perception to } \\
\text { another }\end{array}$ & $\begin{array}{l}\text { - frequent contact and much } \\
\text { support from sister } \\
\text { niece who provides } \\
\text { transportation } \\
\text { frequent contact with } \\
\text { friends by telephone } \\
\text { two confidants }\end{array}$ & - widow & $\begin{array}{l}\text { - have visited with } \\
\text { friends less often } \\
\text { although has main- } \\
\text { tained contact by } \\
\text { telephone }\end{array}$ \\
\hline & & $\begin{array}{l}\text { Other well-Being Indicators } \\
\text { and Standard Deviation } \\
\text { from Sample Mean (Stage 1) }\end{array}$ & Solf-Rated Health & Unique Characteristics & $\begin{array}{c}\text { Control Ovex Life Events } \\
\text { (Stage 2) }\end{array}$ \\
\hline . & & $\begin{array}{l}\text { - activity level near } \\
\text { sample mean }(-.00) \\
\text { - high daily functioning } \\
\text { (.49) } \\
\text { - low medical status }(-.38) \\
\text { - low cognitive status }(-.49) \\
\text { - high housing }(.72) \\
\text { - high income }(.97) \\
\text { - life satisfaction slightly } \\
\text { below the mean }(-.23) \\
\text { soclal contact near mean } \\
\text { (-.17) }\end{array}$ & $\begin{array}{l}\text { Stage } 2 \text { - fair. } \\
\text { Stage } 2 \text { - good }\end{array}$ & $\begin{array}{l}\text { seemed to be very } \\
\text { independent } \\
\text { seemed impatient with } \\
\text { some interview } \\
\text { questions } \\
\text { low cognitive score } \\
\text { seems to be in error }\end{array}$ & $\begin{array}{l}\text { - she solves her problems } \\
\text { quite easily } \\
\text { says she can care for } \\
\text { herself in most } \\
\text { situations } \\
\text { - takes care of much of } \\
\text { her own care } \\
\text { - controls own leisure } \\
\text { has access to others } \\
\text { via telephone }\end{array}$ \\
\hline
\end{tabular}

\begin{tabular}{|c|c|c|c|c|c|}
\hline $\begin{array}{l}\text { Name and } \text { nge } \\
\text { (Stage 1, 1975) } \\
\end{array}$ & $\begin{array}{l}\text { Luving Situation } \\
\text { (Stage } 2,1977) \\
\text { Satisfaction }\end{array}$ & $\begin{array}{c}\text { Self-Concept } \\
\text { Stage } 2 \\
\end{array}$ & Positive Aspects & $\begin{array}{l}\text { Social supports - Stage } 2 \\
\text { Negative Aspects }\end{array}$ & $\begin{array}{c}\text { Change } \\
\text { (stage 1-Stage 2) }\end{array}$ \\
\hline $\begin{array}{l}\text { MRS. MORGAN } \\
83 \text { years }\end{array}$ & $\begin{array}{l}\text { - nursing home (predicted } \\
\text { connunity) } \\
\text { - very satisfled; nursing } \\
\text { home better than } \\
\text { average and food good }\end{array}$ & $\begin{array}{l}\text { - high total self-concept } \\
\text { (.69 SD above sample } \\
\text { nean) } \\
\text { - high or above nean in } \\
\text { all areas except } \\
\text { physical self } \\
\text { - low self-criticism } \\
\text { some inconsistency in } \\
\text { response }\end{array}$ & $\begin{array}{l}\text { - son and family in } \\
\text { metropolitan area; } \\
\text { many positive comments } \\
\text { about relationship }\end{array}$ & $\begin{array}{l}\text { - limited contact with } \\
\text { friends and relatives } \\
\text { (every six months) }\end{array}$ & $\begin{array}{l}\text { - sees son and friends } \\
\text { about the same } \\
\text { - sees relatives less } \\
\text { often }\end{array}$ \\
\hline & \multirow[t]{2}{*}{$\cdot$} & $\begin{array}{l}\text { Other Well-Being Indicators } \\
\text { and Standard Deviation } \\
\text { fron Sample Hean (Stage 1) }\end{array}$ & Self-Rated Health & Unique Characteristics & $\begin{array}{c}\text { Control Over Life Events } \\
\text { (Stage 2) }\end{array}$ \\
\hline & & $\begin{array}{l}\text { - low activity (-1.32) } \\
\text { - high daily functioning } \\
\text { (.49) } \\
\text { - low medical status (-.78) } \\
\text { - high cognitive status } \\
\text { (.94) } \\
\text { - high housing (1.11) } \\
\text { - mean income (.05) } \\
\text { - low life satisfaction } \\
\text { (-1.05) } \\
\text { - social contact slightly } \\
\text { above mean (.31) }\end{array}$ & $\begin{array}{l}\text { Stage } 1 \text { - poor } \\
\text { Stage } 2 \text { - fair }\end{array}$ & $\begin{array}{l}\text { - very intelligent; } \\
\text { interested in inter- } \\
\text { view; pleasant } \\
\text { - well-read } \\
\text { seems to have realistic } \\
\text { view of situation }\end{array}$ & $\begin{array}{l}\text { - says she can solve some } \\
\text { but not all problems } \\
\text { quite easily } \\
\text { says she cannot take } \\
\text { care of herself in } \\
\text { most situations } \\
\text { dependent on staff for } \\
\text { all personal care }\end{array}$ \\
\hline
\end{tabular}




\begin{tabular}{|c|c|c|c|c|c|}
\hline $\begin{array}{l}\begin{array}{l}\text { name and Age } \\
\text { (stage 1, 1975) }\end{array} \\
\text { Stage }\end{array}$ & 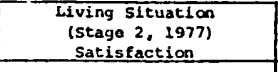 & $\begin{array}{l}\text { Self-Concept } \\
\text { stage 2 }\end{array}$ & Positive Aspects & $\begin{array}{l}\text { Social Supports - Stage } 2 \\
\text { Negative Agpects }\end{array}$ & $\begin{array}{c}\text { Change } \\
\text { (stage 1-stage 2) } \\
\end{array}$ \\
\hline \multirow[t]{3}{*}{$\begin{array}{l}\text { URS. CARTER } \\
80 \text { or } 90 \text { years }\end{array}$} & 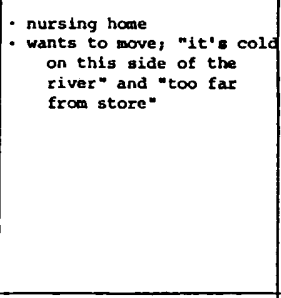 & 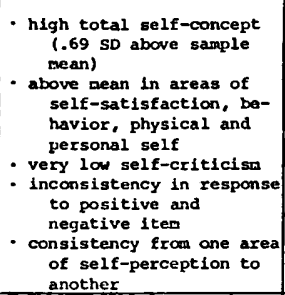 & - conservator & $\begin{array}{l}\text { widow } \\
\text { no children } \\
\text { no relatives in area--no } \\
\text { contact with nieces } \\
\text { no contact with friends }\end{array}$ & $\begin{array}{l}\text { - less cantact with } \\
\text { friends and relatives }\end{array}$ \\
\hline & & $\begin{array}{l}\text { Other well-Being Indicators } \\
\text { and standard Deviation } \\
\text { fron sarple Mean (staga is }\end{array}$ & Self-Rated Health & Unique Characteristics & $\begin{array}{c}\text { Control over Lufe Events } \\
\text { (stage } 21\end{array}$ \\
\hline & & 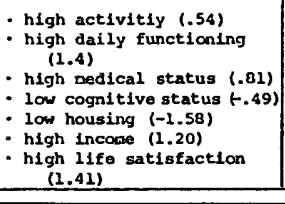 & $\begin{array}{l}\text { Stage } 1-\text { good } \\
\text { stage } 2-\text { good }\end{array}$ & $\begin{array}{l}\text { - very friendly, interested } \\
\text { in talking about her } \\
\text { past } \\
\text { very poor mesory } \\
\text { - seens to spend most of } \\
\text { her time in her roor } \\
\text { - unrealistic view }\end{array}$ & $\begin{array}{l}\text { - says she does not solve } \\
\text { problems easily } \\
\text { says she can take care } \\
\text { of herself in any } \\
\text { situation }\end{array}$ \\
\hline \multirow{2}{*}{\begin{tabular}{|l|} 
Name and Age \\
(Stage 1, 1975) \\
Mrs. SMITH \\
B3 years \\
\end{tabular}} & $\begin{array}{l}\text { Living Situation } \\
\text { (stage 2. } 21977 \text { ) } \\
\text { Satisfaction }\end{array}$ & $\begin{array}{l}\text { Self-concept } \\
\text { Stage } 2\end{array}$ & \multicolumn{3}{|c|}{$\begin{array}{c}\text { Social Supports - Stage } 2 \\
\text { Negative Aspects }\end{array}$} \\
\hline & 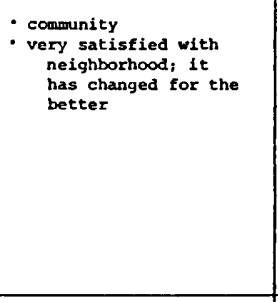 & 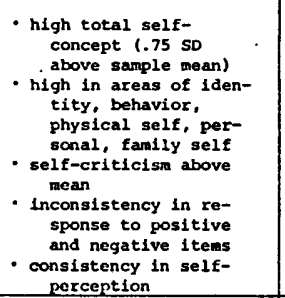 & 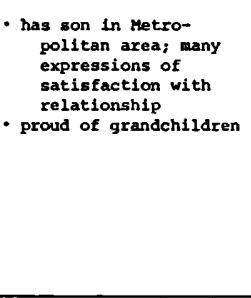 & $\begin{array}{l}: \text { no confidants } \\
\text { contact with friends } \\
\text { monthly } \\
\text { widowed as a yound } \\
\text { woman }\end{array}$ & - about same \\
\hline \multirow{2}{*}{\multicolumn{2}{|c|}{. }} & 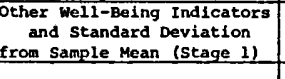 & Self-kated Mealth & Unique Characteristics & $\begin{array}{l}\text { Control over Life Events } \\
\text { (Stage 2) }\end{array}$ \\
\hline & & 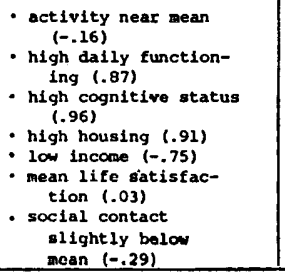 & $\begin{array}{c}\text { stage } 1 \text { - good } \\
\text { stage } 2 \\
2-\operatorname{good} \\
.\end{array}$ & 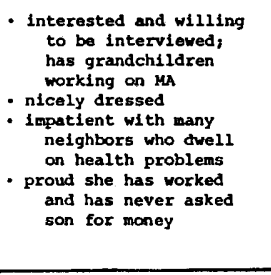 & 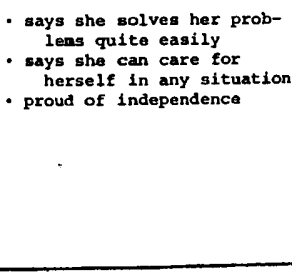 \\
\hline
\end{tabular}




\begin{tabular}{|c|c|c|c|c|c|}
\hline $\begin{array}{c}\text { Name and } \lambda g e \\
\text { (Stage } 1,1975 \text { ) } \\
\end{array}$ & $\begin{array}{c}\text { Living Situation } \\
\text { (Stage 2, 1977) } \\
\text { Satisfaction } \\
\end{array}$ & $\begin{array}{c}\text { Self-Concept } \\
\text { Stage 2 }\end{array}$ & Positive Aspects & $\begin{array}{l}\text { Social Supports - Stage } \overline{2} \\
\text { Negative Aspects }\end{array}$ & $\begin{array}{c}\text { Change } \\
\text { (stage 1-stage 2) }\end{array}$ \\
\hline \multirow[t]{3}{*}{$\begin{array}{l}\text { MR. LANDOH } \\
68 \text { years }\end{array}$} & $\begin{array}{l}\text { - community } \\
\text { neighborhood good place } \\
\text { to live } \\
\text { - does not like some of } \\
\text { the tenants in the } \\
\text { apartment complex }\end{array}$ & $\begin{array}{l}\text { - high total self-concept } \\
\text { (.78 SD above sample } \\
\text { mean) } \\
\text { - high in areas of self- } \\
\text { satisfaction, behavior, } \\
\text { moral-ethical, personal, } \\
\text { social self } \\
\text { - very low self-criticism } \\
\text { - consistency in response } \\
\end{array}$ & $\begin{array}{l}\text { married } \\
\text { confidants } \\
\text { regular, frequent } \\
\text { cantact with relatives } \\
\text { and friends }\end{array}$ & - no chtldren & - same \\
\hline & & $\begin{array}{l}\text { Other Well-Being Indicators } \\
\text { and standaxd Deviation } \\
\text { from Sample Mean (Stage 1) }\end{array}$ & Self-Rated Health & Unique Characteristics & $\begin{array}{c}\text { Control Over Life Events } \\
\text { (Stage 2) }\end{array}$ \\
\hline & . & $\begin{array}{l}\text { - high activity (1.67) } \\
\text { - daily functioning slightly } \\
\text { above nean }(.31) \\
\text { - medical status slightly } \\
\text { below nean }(-.26) \\
\text { - low cognitive status }(-1.17) \\
\text { - low housing status (-.48) } \\
\text { - low income (-1.39) } \\
\text { - high life satisfaction } \\
\text { (.72) } \\
\text { - social contact near } \\
\text { sample mean (.16) }\end{array}$ & $\begin{array}{l}\text { Stage } 1-\text { fair } \\
\text { Stage } 2-\text { good }\end{array}$ & $\begin{array}{l}\text { - very friendly, but shy } \\
\text { cognitive status score } \\
\text { may be in error } \\
\text { - wife pleasant, sonewhat } \\
\text { donainating }\end{array}$ & $\begin{array}{l}\text { - says he solves problems } \\
\text { easily ("so far") } \\
\text { - says he cannot take } \\
\text { care of himself in } \\
\text { all situations } \\
\text { - able to get out of home } \\
\text { - dependent upon wife for } \\
\text { support and assistance } \\
\text { in personal care }\end{array}$ \\
\hline
\end{tabular}

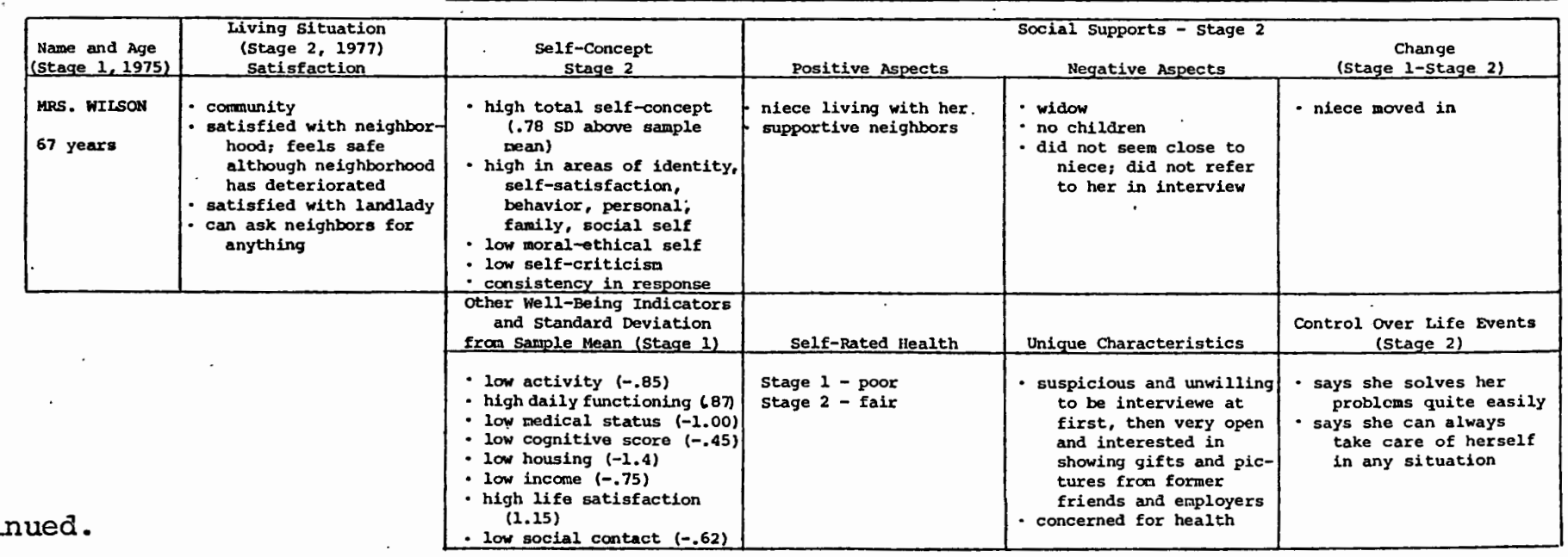




\begin{tabular}{|c|c|c|c|c|c|}
\hline $\begin{array}{c}\text { Name and Age } \\
\text { (Stage 1, 1975) }\end{array}$ & $\begin{array}{c}\text { Living gituation } \\
\text { (Stage 2, 1977) } \\
\text { Satisfaction } \\
\end{array}$ & $\begin{array}{c}\text { Self-Concept } \\
\text { Stage } 2 \\
\end{array}$ & Positive Aspects & $\begin{array}{l}\text { Soc1al Supports - Stage } 2 \\
\text { Negative Aspects }\end{array}$ & $\begin{array}{c}\text { Change } \\
\text { (stage 1-stage 2) }\end{array}$ \\
\hline \multirow[t]{3}{*}{$\begin{array}{l}\text { NRS. NELSON } \\
79 \text { years }\end{array}$} & \multirow[t]{3}{*}{$\begin{array}{c}\cdot \text { community } \\
\text { - very satisfied, has } \\
\text { good neighbors }\end{array}$} & $\begin{array}{c}\text { - high total self concept } \\
\text { (.93 SD above sample } \\
\text { mean) } \\
\text { - high in areas of identi- } \\
\text { ty, self-satisfaction, } \\
\text { behavior, physical and } \\
\text { social self } \\
\text { - low self-criticism } \\
\text { - consistency in response }\end{array}$ & $\begin{array}{l}\text { - close friend and neigh- } \\
\text { bor Mr. Brown provides } \\
\text { transportation and } \\
\text { other support } \\
\text { - Mr. Brow's daughter } \\
\text { provides support } \\
\text { - Husband's relatives liv- } \\
\text { Ing in neighborhood }\end{array}$ & $\begin{array}{l}\text { - widow } \\
\text { no childaren } \\
\text { Mr. Brom scheduled for } \\
\text { major surgery } \\
\text { unsatisfactory relation- } \\
\text { ship with husband's } \\
\text { relatives }\end{array}$ & - closer to Mr. Brom \\
\hline & & $\begin{array}{l}\text { other Well-Being Indicator } \\
\text { and Standard Deviation } \\
\text { from Sample Mean (Stage 1) }\end{array}$ & Self-Rated Health & Unique Characteristics & $\begin{array}{c}\text { Control Over Life Events } \\
\text { (Stage 2) }\end{array}$ \\
\hline & & 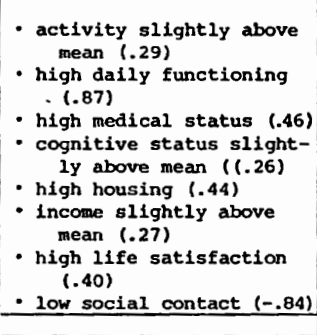 & $\begin{array}{l}\text { Stage } 1-\text { good } \\
\text { Stage } 2=\text { good }\end{array}$ & $\begin{array}{l}\text { - willing to be inter- } \\
\text { viewed } \\
\text { sense of humor } \\
\text { - fearful of own future, } \\
\text { especially fears } \\
\text { nursing home; husband } \\
\text { and sister died in one } \\
\text { fearful for Mr. grown } \\
\text { and what will happen } \\
\text { to him } \\
\text { avid sports fan } \\
\text { takes care of garden }\end{array}$ & $\begin{array}{l}\text { says she solves some } \\
\text { problens but not } \\
\text { others easily } \\
\text { says she cannot take } \\
\text { care of herself in } \\
\text { all situations } \\
\text { very fearful of future } \\
\text { and her ability to } \\
\text { cope without Mr. } \\
\text { Brown }\end{array}$ \\
\hline $\begin{array}{c}\text { Name and Age } \\
\text { (Stäge 1, 1975) }\end{array}$ & $\begin{array}{l}\text { Living situation } \\
\text { (Stage } 2,1977 \text { ) } \\
\text { Satisfaction } \\
\end{array}$ & $\begin{array}{c}\text { Self-Concept } \\
\text { Stage 2 } \\
\end{array}$ & \multicolumn{3}{|c|}{$\begin{array}{l}\text { Social Supports - Stage } 2 \\
\text { Negative Aspects }\end{array}$} \\
\hline $\begin{array}{l}\text { MR HARRIS } \\
81 \text { years }\end{array}$ & $\begin{array}{l}\text { - nursing home } \\
\text { somewhat satisfied } \\
\text { has made many friends } \\
\text { in nursing home, } \\
\text { participates in } \\
\text { activities }\end{array}$ & $\begin{array}{l}\text { - high total self concept } \\
\text { (1.64 SD above sample } \\
\text { mean) } \\
\text { - high in all areas of } \\
\text { self concept } \\
\text { - ow self criticism } \\
\text { - consistency in response }\end{array}$ & $\begin{array}{l}\text { - daughter in Metropolitan } \\
\text { area who visits fre- } \\
\text { quently } \\
\text { - spends weekends with } \\
\text { daughter monthly: } \\
\text { satisfied with rela- } \\
\text { tionship } \\
\text { - frequent contact with } \\
\text { friends; spends } \\
\text { weekends with them } \\
\text { monthly } \\
\text { - friends in nursing home }\end{array}$ & $\begin{array}{l}\text { - widower } \\
\text { cried when talking about } \\
\text { siblings; all are } \\
\text { dead }\end{array}$ & $\begin{array}{l}\text { has seen daughter and } \\
\text { friends about same }\end{array}$ \\
\hline \multirow[b]{2}{*}{. } & & $\begin{array}{l}\text { other well-Being Indicators } \\
\text { and Standard Deviation } \\
\text { from Sample Mean (Stage 1) } \\
\end{array}$ & Self-Rated Health & Unique Characteristics & $\begin{array}{c}\text { Control over Life Events } \\
\text { (Stage 2) }\end{array}$ \\
\hline & & $\begin{array}{l}\text { - activity near mean }(.14) \\
\text { - high daily functioning } \\
\text { (.49) } \\
\text { - low medical status (-.62) } \\
\text { - low cognitive status. } \\
\text { (-1.19) } \\
\text { - high housing }(.72) \\
\text { - low income }(-. .41) \\
\text { - high life satisfaction } \\
\text { (.59) } \\
\text { - social contact near } \\
\text { mean (1.06) }\end{array}$ & $\begin{array}{l}\text { Stage } 1 \text { - good } \\
\text { Stage } 2 \text { - fair }\end{array}$ & $\begin{array}{l}\text { - Stage } 1 \text { described as } \\
\text { lethargic, depressed } \\
\text { cried easily } \\
\text { - lived with friend who } \\
\text { said whe would not let } \\
\text { his be put in nursing } \\
\text { home } \\
\text { friend said daughter } \\
\text { wanted him in nursing } \\
\text { home } \\
\text { - in nursing home active, } \\
\text { interested }\end{array}$ & $\begin{array}{l}\text { says he solves his prob- } \\
\text { loms quite easily } \\
\text { says he cannot take care } \\
\text { of himself in all } \\
\text { situations } \\
\text { able to leave nursing } \\
\text { home for visits }\end{array}$ \\
\hline
\end{tabular}




\begin{tabular}{|c|c|c|c|c|c|}
\hline $\begin{array}{l}\text { Name and } \mathrm{kge} \\
\text { (stage 1, 1975) }\end{array}$ & $\begin{array}{c}\text { EIving Bituation } \\
\text { (Stage } 2,1977) \\
\text { Satisfaction } \\
\end{array}$ & $\begin{array}{c}\text { solt-Concept } \\
\text { Stage } 2\end{array}$ & Positive Aspects & $\begin{array}{l}\text { Socinl supports - stago } 2 \\
\text { Negative Aspects }\end{array}$ & $\begin{array}{c}\text { Change } \\
\text { (stage 2-stage 2) }\end{array}$ \\
\hline \multirow[t]{3}{*}{$\begin{array}{l}\text { MRS. FOSTER } \\
78 \text { years }\end{array}$} & $\begin{array}{l}\text { nursing home } \\
\text { : somenhat satisfied } \\
\text { "I have to be." }\end{array}$ & $\begin{array}{l}\text { - total self concept near } \\
\text { mean (.03 sD abovo } \\
\text { sample mean) } \\
\text { - low in areas of self- } \\
\text { satisfaction and physi- } \\
\text { cal self } \\
\text { - high in sreas of family } \\
\text { and social self } \\
\text { low self-criticism } \\
\text { - scame inconsistency in } \\
\text { response }\end{array}$ & - son; meekly visits & $\begin{array}{l}\text { - no contact with friends } \\
\text { or rolatives } \\
\text { vague, non-comaltal } \\
\text { when discussing son }\end{array}$ & - about the same \\
\hline & & $\begin{array}{l}\text { other wel11-being Indicators } \\
\text { and standard Deviat fon } \\
\text { from Sample Mean (Stage 1) }\end{array}$ & Self-Rated Health & Unlque Characteristics & $\begin{array}{c}\text { Control Over Life Events } \\
\text { (Stage 2) }\end{array}$ \\
\hline & & 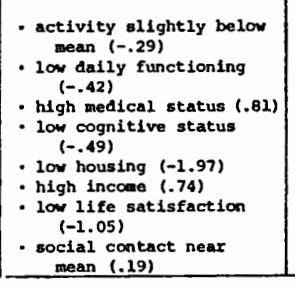 & $\begin{array}{l}\text { Stage } 1-\text { poor } \\
\text { stage } 2-\text { poor }\end{array}$ & $\begin{array}{l}\text { - seems preoccupled with } \\
\text { poor health } \\
\text { - stays in bed most of } \\
\text { the time } \\
\text { - willing to be inter- } \\
\text { viewed; some question } \\
\text { about zesponses }\end{array}$ & $\begin{array}{l}\text { - says she does not solve } \\
\text { most problems easily } \\
\text { says she cannot take } \\
\text { care of herself in } \\
\text { most situations } \\
\text { spends most of time in } \\
\text { room; refuses } \\
\text { activities }\end{array}$ \\
\hline $\begin{array}{l}\text { Name and Age } \\
\text { (Stage 1, 1975) }\end{array}$ & $\begin{array}{c}\text { Living Situation } \\
\text { (stage } 2,1977 \text { ) } \\
\text { Satisfaction } \\
\end{array}$ & $\begin{array}{c}\text { Self-Concept } \\
\text { Stage 2 }\end{array}$ & Positive Aspects & $\begin{array}{l}\text { Social Supports - Stage } 2 \\
\text { Negative Aspects }\end{array}$ & $\begin{array}{c}\text { Change } \\
\text { (Stage 1-stage 2) }\end{array}$ \\
\hline \multirow[t]{3}{*}{$\begin{array}{l}\text { MRS. WILLIAMS } \\
98 \text { years }\end{array}$} & $\begin{array}{l}: \text { nursing homo } \\
\text { very dissatisfied, } \\
\text { meals are poor }\end{array}$ & 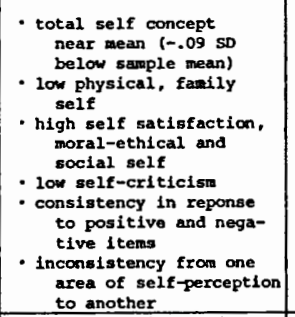 & $\begin{array}{l}\text { - visited weekly by } \\
\text { Christian Science } \\
\text { practitioner }\end{array}$ & $\begin{array}{l}\text { - divorced (when young } \\
\text { woman) } \\
\text { - no children } \\
\text { no relatives in state; } \\
\text { no contact with } \\
\text { nephew } \\
\text { - no contact with friends }\end{array}$ & $\begin{array}{l}\text { sees Christian Science } \\
\text { practitioner more } \\
\text { often }\end{array}$ \\
\hline & & $\begin{array}{l}\text { Other well-Being Indicators } \\
\text { and Standard Devilition } \\
\text { from Sample Mean (Stage 1) }\end{array}$ & Self-Rated Health & Unique Characteristics & $\begin{array}{c}\text { Control Over Life Events } \\
\text { (Stage 2) }\end{array}$ \\
\hline & & 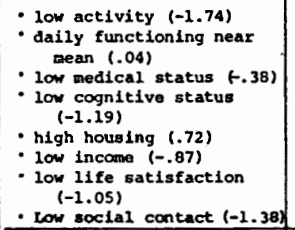 & $\begin{array}{l}\text { Stage } 1-\text { good } \\
\text { stage } 2-\text { good }\end{array}$ & $\begin{array}{l}\text { - willing to be inter- } \\
\text { viewed; impatient with } \\
\text { portions } \\
\text { conitive status seemed } \\
\text { high } \\
\text { many expressions of } \\
\text { anger; many complaints } \\
\text { - seems to have realistic } \\
\text { view of situation }\end{array}$ & 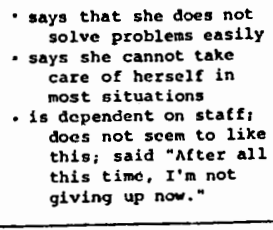 \\
\hline
\end{tabular}




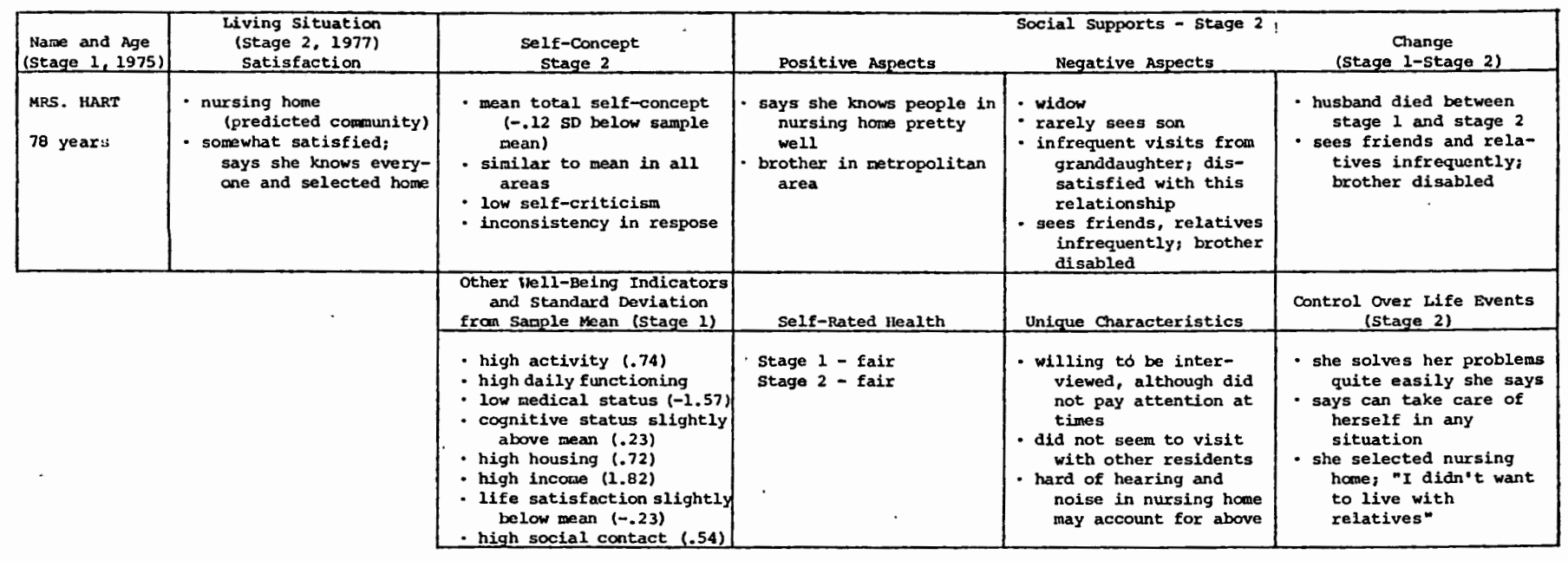

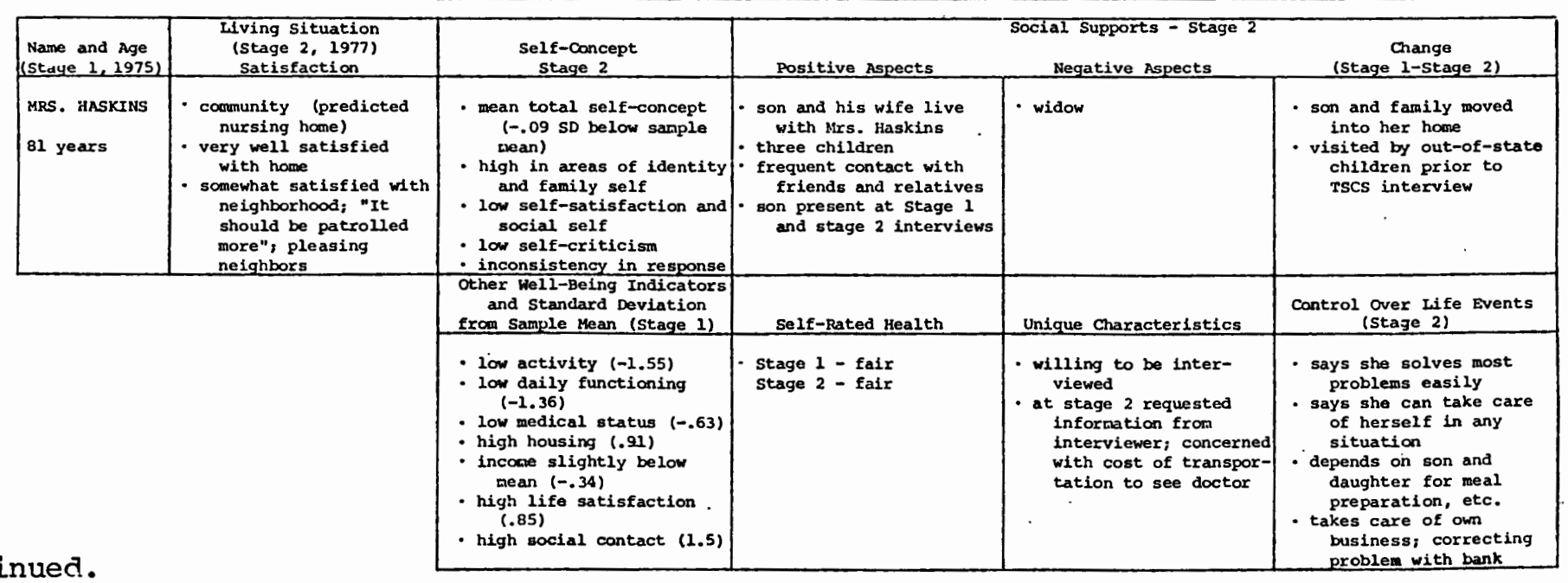




\begin{tabular}{|c|c|c|c|c|c|}
\hline $\begin{array}{c}\text { Name and Age } \\
\text { (Stage } 1,1975) \\
\end{array}$ & $\begin{array}{l}\text { Living Situation } \\
\text { (Stage 2, 1977) } \\
\text { Satisfaction } \\
\end{array}$ & $\begin{array}{l}\text { Self-Concept } \\
\text { Stage 2 }\end{array}$ & Positive Aspects & $\begin{array}{l}\text { Social Supports - Stage } 2 \\
\text { Negative Aspects } \\
\end{array}$ & $\begin{array}{c}\text { Change } \\
\text { (stage 1-stage 2) } \\
\end{array}$ \\
\hline \multirow[t]{3}{*}{$\begin{array}{l}\text { MRS. ROBERTS } \\
88 \text { years }\end{array}$} & $\begin{array}{l}\text { - community (predicted } \\
\text { nursing home) } \\
\text { somewhat satisfied; } \\
\text { wish neighbors were } \\
\text { nore friendly }\end{array}$ & $\begin{array}{c}\text { low total self-concept } \\
\text { (-1.31 sD below sample } \\
\text { mean) } \\
: \text { low in all areas } \\
: \text { low self-criticism } \\
\text { inconsistency in response }\end{array}$ & $\begin{array}{l}\text { - has housekeeper (also } \\
\text { niece) } \\
\text { - has son }\end{array}$ & $\begin{array}{l}\text { - widow } \\
\text { little or no contact } \\
\text { with son } \\
\text { no contact with friends } \\
\text { or relatives }\end{array}$ & $\begin{array}{l}\text { - obtained housekeeper } \\
\text { decline in contact } \\
\text { with friends }\end{array}$ \\
\hline & \multirow[b]{2}{*}{. } & $\begin{array}{l}\text { Other well-Being Indicators } \\
\text { and standard Deviation } \\
\text { from Sample Mean (Stage 1) }\end{array}$ & Self-Rated Health & Unicue Characteristics & $\begin{array}{c}\text { Control Over Life Events } \\
\text { (Stage 1) }\end{array}$ \\
\hline & & $\begin{array}{l}\text { - activity slightly above } \\
\text { mean (.33) } \\
\text { - daily functioning slight1 } \\
\text { above mean (.24) } \\
\text { - high medical status (.46) } \\
\text { - low cognitive status } \\
\quad(-1.87) \\
\text { - low housing }(-1.4) \\
\text { - high life satisfaction } \\
\text { (.40) } \\
\text { - low social contact }(-.62)\end{array}$ & $\begin{array}{l}\text { Stage } 1-\text { good } \\
\text { Stage } 2-\text { good }\end{array}$ & $\begin{array}{l}\text { - very confused; very } \\
\text { poor memory } \\
\text { - willing to be inter- } \\
\text { viewed, but had diffi- } \\
\text { culty answering ques- } \\
\text { tions; became anxious } \\
\text { by the end } \\
\text { - said she was the "13th } \\
\text { child of 23" } \\
\text { - housekeeper faith } \\
\text { healer and dowser }\end{array}$ & $\begin{array}{l}\text { - says she solves some } \\
\text { but not all problems } \\
\text { easily } \\
\text { says she can take care } \\
\text { of herself in any } \\
\text { situation } \\
\text { - dependent upon house- } \\
\text { keeper }\end{array}$ \\
\hline
\end{tabular}

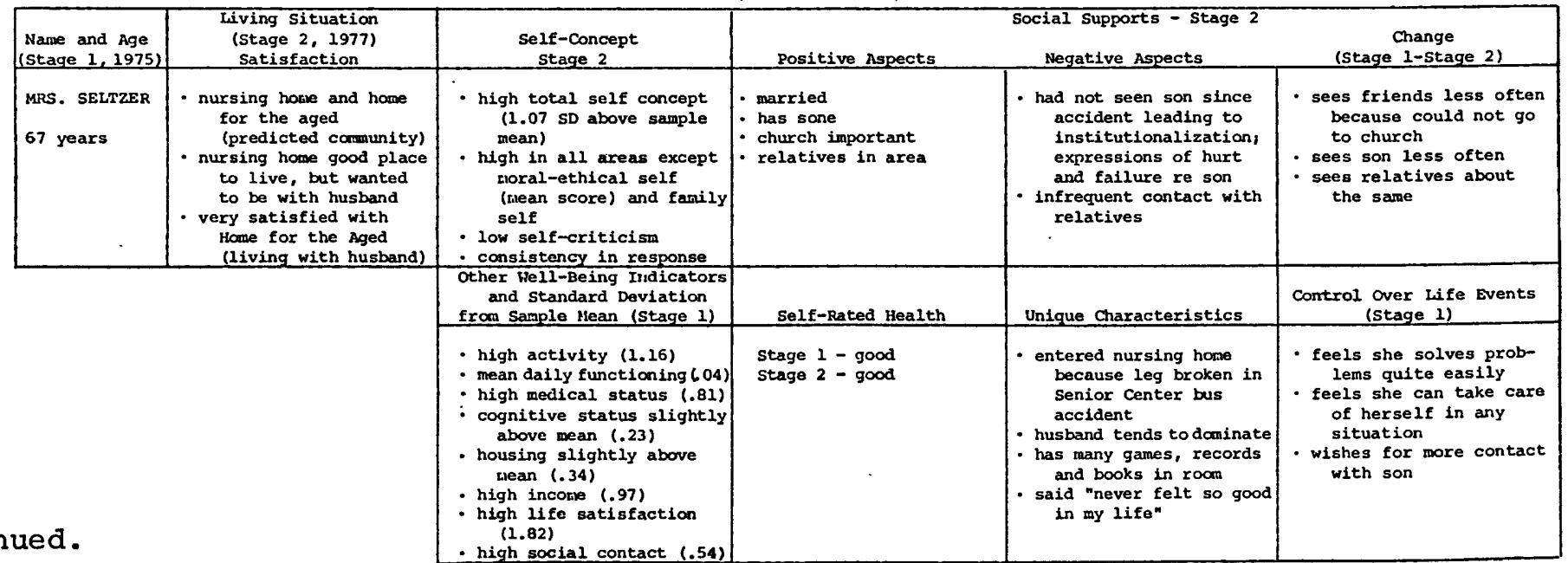


below the sample mean (e.g., social self). High or low self-criticism scores and consistency of response are also included. Consistency in response refers both to (1) consistency in response to positive and negative items, and (2) consistency in perception of the self in the internal and external frames of reference.

Positive and negative aspects of social supports reflect the presence or absence of support persons and also qualitative aspects of social relationships at stage 2 . Changes in relationships and frequency of contact from stage 1 to stage 2 are also included.

Well-being indicators (see Appendix I) provide information concerning the individual's status at stage 1. Each person's individual scores were compared to the mean scores of the appropriate sample from the larger study (institutionalized, $n=40$; community, $n=227$ ). The sample from the larger study was chosen because these scores were felt to be more representative of the two groups. The standard deviations from the larger study sample means are presented next to each indicator in the chart.

The category "control of life events" involves two types of information. First, there are responses to two items of the TSCS: "I solve my problems quite easily" and "I can take care of myself in any situation." other information on control is derived from respondent comments and interviewer observations.

"Unique characteristics" provides useful information about the circumstances surrounding the individual and personal characteristics which have not been captured by the formal measures. This information provides valuable insight into the individual's self-concept, relation- 
ship to others, and feelings concerning those relationships. Information included under the heading "unique characteristics" is: the interview setting, the respondents' interest in the interview, his/her reactions to questions, and comments made during the interview.

Social participation. Examination of the case studies is very revealing. In examining the qualitative aspects of social participation, relationships with children and relatives do seem to be very important variables. Furthermore, it is clear that the survey measures used in the interviews were inadequate for capturing the flavor of these relationships. The social indicators largely measured the amount of potential social support available $(e . g .$, number of children in the area); however, the quality of this support or the nature of the relationship was not reflected in the scores. As seen in the cases of Mrs. Goodman, Mrs. Grogan, and Mrs. Jones, the presence of children or even frequent contact is not necessarily satisfying or beneficial in terms of providing support or affective ties. Similarly, some of the respondents had low social contact scores when there appeared to be important support available. Mr. Landon and Mrs. Anderson are examples. The quality of social relationships appears crucial when examining self-concept. Twelve individuals had positive total selfconcept scores (standard deviations ranged from .42 to 1.64 above the mean). All but one of these individuals, Mrs. Carter, reported having satisfying and supportive relationships with friends and relatives. Mrs. Carter did not report any current negative or positive relationships. It appeared that their friends and family had died or that she had simply lost contact. However, it is important to note that Mrs. 
Carter had an extremely poor memory; she was pleasant and cheerful, but did not seem overly concerned about contacting others.

of the 12 with high self-concept scores, only three, Mrs. Seltzer, Mrs. Nelson and Mrs. Wilson, expressed any dissatisfaction with some apsect of their social relationships. Mrs. Seltzer had been institutionalized as a result of a bus accident and had not seen her son, who lived in the area, since that time. Mrs. Seltzer and her husband appeared hurt and made comments like, "I think we missed the boat with our son." Mrs. Nelson felt that her husband's relatives disapproved of her friendship with her neighbor, Mr. Brown. She did not feel that these relatives were particularly concerned about her or were a potential source of support. Mrs. Wilson's niece lived with her, but during the interview Mrs. Wilson referred to her only once: "My niece has a big mouth, but I try not to let it bother me."

All three of these respondents had other persons close to them who provided friendship and support: Mrs. Seltzer's husband, Mrs. Nelson's friend, and Mrs. Wilson's neighbors. This support seemed to compensate for the negative feelings toward the son, relatives and the niece. It is likely that those persons providing support were more important to the respondents in defining and shaping self-concept than those whose relationships were viewed negatively. It would be useful to have data regarding these relationships 10,20 , or 30 years prior to the interview. This would enable researchers to more thoroughly examine the process of defining one's self over time and how specific individuals (e.g., son, husband) contributed to this process.

Of the eight persons with low total self-concept scores (standard deviations ranging from -.50 to -2.47 ) all but two, Mrs. Sanders and 
Mr. Hawkins, indicated that they had an unsatisfactory relationship with children or other relatives. Examples of the characteristics of poor relationships included disapproval of children's lifestyles, distrust of children's or relatives' motives and actions, and disappointment in friends' lack of suppoxt.

Mrs. Sanders case is somewhat puzzling. She appeared to have many good friends and relatives and had frequent contact with them by phone. Her roommate had become a close friend and Mrs. Sanders was a favorite of the staff. She spoke warmly of her daughter and spoke with her by phone daily. In spite of her many contacts and visits from others, however, she had a low self-concept score. A possible explanation of this may be found in the fact that she experienced a decrease in the amount of face to face contact. Visiting in person may be an important aspect for hex in relating with others. Also, Mrs. Sanders' daughter was in very poor health and there appeared to be considerable concern for her well-being. It is important to note here that Mrs. Sanders' life satisfaction score at stage 1 was one standard deviation below the mean, suggesting that her low self-concept was a continuation of self-perception formed earlier. It would be useful to be able to examine Mrs. Sanders' earlier social relationships to determine if there had been unsatisfactory relationships with significant persons in the past.

Like Mrs. Sanders, Mr. Hawkins reported no negative social relationships. At the same time, however, according to the stage 1 interview, he was divorced or separated. Similarly, although he had recently been visited by his sister, prior to that time he had not seen her for 10 years. Moreover, although at Stage $1 \mathrm{Mr}$. Hawkins reported 
having 10 confidants, at stage 2 he did not appear to have maintained any contact with friends. This is suggestive of poor relationships in the past.

In sum, examination of the case studies indicates that, with few exceptions, a positive self-concept is closely associated with satis fying social relationships with relatives and others. It also appears that the presence of an important person and source of support may outweigh negative relationships in influencing self-concept. Again, to fully explore the role of these persons in the process of defining one's self-concept requires more extensive longitudinal data.

The major hypothesis for this study was also concerned with determining if changes in the amount and kind of contact with friends and relatives, particularly for those who were institutionalized, were associated with negative self-concepts. Five of eight persons with low self-concepts reported some decrease in social contact compared to four of twelve persons with positive self-concepts. Most of those experiencing a decrease in social contact were nursing home residents. It is interesting to note that three of the eight persons with low selfconcept scores and two with high scores had experienced some increase in the amount of social contact with friends and relatives.

From examining the case studies, it appears that change in the amount of social contact is not related to self concept. It would seem that, except in the case of Mrs. Sanders, the quality of the relationship is more closely associated with self-concept than is a decrease in the amount of contact with others.

Well-being Indicators. The case studies also indicate other variables which might explain differences in self-concept. For example, 
examination of the well-being indicators at Stage 1 show that those with positive self-concepts were likely to have more scores above the mean than below. On the other hand, those with low self-concept scores were likely to have more negative than positive scores, This suggests that an accumulation of negative attributes is associated with a negative self-concept. This may provide added insight into the low self-concept scores of Mrs. Sanders and Mr. Hawkins and the high scores of Mrs. Seltzer and Mrs. Nelson. Mrs. Sanders was above the mean in only two of the eight well-being indicators, social contact and housing. Similarly, Mr. Hawkins was scored above the mean in three areas: income, social contact, and cognitive status. It is important to note that Mr. Hawkins' scores may be inaccurate and it is likely that he was poorer and more socially isolated than he reported. Mrs. Seltzer and Mrs. Nelson reported generally high levels of well-being at Stage.l. Mrs. Seltzer had no scores below the mean and Mrs. Nelson had only one low score, social contact. These findings suggest that an accumulation of negative conditions or circumstances are related to negative selfconce $_{\text {is, }}$ while a generally high status of well-being contributes to a positive self-concept.

Control. Control is another variable which may be related to self-concept. In various studies, the ability of the old person to control or predict aspects of the environment has been shown to be positively related to psychological well-being (Schulz, 1976). In this study control was measured by self-perceptions regarding one's ability to problem solve and the ability to care for oneself in any situation. In examining the case studies there appear to be few differences between the high and low self-concept groups regarding perceived control. 
The case studies also provide information concerning the ability of the respondents to control various aspects of their life, such as the ability to control one's leisure activities, the ability to control. money, to make decisions, and so forth. Such indicators clearly need to be refined and standardized. However, the case studies do seem to indicate that those with positive self-concepts tend to control their activities to a greater degree than those with negative self-concepts.

Summary, Hypothesis I. In summary, the hypothesis that institutionalized individuals who experience decreases in the amount and kind of social interaction with friends and family will have less positive self-concepts than those who live in their own homes and/or maintain these relationships was not supported. First, there were no significant differences in self-concept between the institutionalized and community groups. Second, neither decreases nor increases in the amount of social contact appeared to be related to self-concept in either the institutionalized or the community sample. At the same time, the study provided a number of significant findings; most notably, self-concept appears to be strongly correlated with satisfying social relationships. This was evidenced both by statistical analysis (i.e., the positive correlations listed in Table VI) and by the case study material. The case studies were particularly important in illustrating the importance of the qualitative aspects of social relationships and for the need to develop quantitative measures which will reflect accurately the nature of these relationships. Finally, other variables also seem to contribute to self-concept. These include general levels of well-being and the ability to control one's activity. These findings require more 
systematic study in order to determine their relative importance in predicting the self-concept of older people.

HYPOTHESIS II

Statistical Analysis

The second hypothesis for this study was multiple in nature and conceived as follows: (a) Individuals who were predicted to become institutionalized (due to poor health and/or cognitive status) but who remained in their own homes were more likely to have stronger social supports than those who entered institutions; and (b) those persons who were predicted to remain in their own homes but who were institutionalized were more likely to have little social support. To test this hypothesis, further analysis was done on data from the larger study analyzed by whitelaw and stewart (1978). The findings of their analysis are summarized below.

Whitelaw and stewart (1978) used analysis of variance to determine if there were significant differences between four outcome groups on the life space indicators described earlier. The outcome groups used were survivors (those who remained in the community), those who were institutionalized, those who were too ill to be interviewed, and those who died. They found that there were differences between groups. Survivors scored higher than the institutionalized group on medical health status, daily functioning, cognitive status, activities, and housing. Survivors also scored higher on social contacts, but this differance was slight. The sample for this study was compared to the large study sample. As can be seen in Table VII, the scores of the study sample were similar to those of the large study. The statistical 
analysis revealed no significant differences, although the difference between life satisfaction scores of the community residing elderly approaches significance $(p=.10)$. Still, the similarity in mean scores on these indicators suggest that the study sample was representative of the larger study. Therefore, statistical analysis was done using the entire sample.

TABIE VII

WELL-BEING INDICATOR SCORE MEANS BY GROUP

\begin{tabular}{|c|c|c|c|c|}
\hline & Institu & nalized & Communi & esiding \\
\hline ACTIVITY & $\begin{array}{l}\text { Study } \\
\text { Sample } \\
2.00\end{array}$ & $\begin{array}{l}\text { Larger } \\
\text { Study } \\
2.28\end{array}$ & $\begin{array}{l}\text { Study } \\
\text { Sample } \\
2.32\end{array}$ & $\begin{array}{l}\text { Larger } \\
\text { Study } \\
2.53\end{array}$ \\
\hline COGNITIVE STATUS & 2.53 & 2.58 & 2.89 & 2.89 \\
\hline HOUSING & 2.67 & 2.83 & 3.14 & 3.01 \\
\hline DAILY FUNCTIONING & 2.54 & 2.45 & 2.88 & 2.86 \\
\hline INCOME & 2.94 & 2.87 & 2.71 & 2.88 \\
\hline MEDICAL HEALTH STATUS & 2.48 & 2.59 & 2.83 & 2.77 \\
\hline LIFE SATISFACTION & 2.52 & 2.69 & 3.04 & 2.72 \\
\hline SOCIAL CONTACT & 2.52 & 2.44 & 2.58 & 2.60 \\
\hline & $\mathrm{N}=12$ & $\mathrm{~N}=\mathbf{2 8}$ & $\mathrm{N}=12$ & $\mathrm{~N}=213$ \\
\hline MEAN AGE & 76.6 & 76.1 & 81 & 80.3 \\
\hline
\end{tabular}

In addition to the analysis of variance, stewart and Whitelaw also conducted a discriminant function analysis. Results indicated that daily functioning, cognitive status, and age differentiated the two groups $(F=18.89,14.56$, and 4.00 , respectively). It is important to note that while age was included in the analysis, both daily functioning and cognitive status were better predictors of 
institutionalization. Based on these variables, 70 percent of the survivors and 72.5 percent of the institutionalized were correctly classified.

The present study's second hypothesis was concerned with those who did not fall into the predicted outcome groups; those who remained in the community in spite of low cognitive and/or daily functioning scores and those who were later institutionalized in spite of relatively high scores on these dimensions. Four groups were examined:

(1) those who survived and were predicted to survive $(n=159)$; (2) those who survived and had been predicted to be institutionalized $(n=68)$; (3) those who were institutionalized but who were predicted to survive $(n=11)$; and

(4) those who were correctly predicted to enter nursing homes $(n=29)$. As discussed earlier, it was hypothesized that social contacts would emerge as an intervening variable in these cases. Specifically, it was predicted that those who were able to survive and live in the community, in spite of poor functioning or a low cognitive status, would have higher social contact scores than those who were unexpectedly institutionalized. In addition, because they survived, they were expected to have more social contact than those who remained in the community. To test this hypothesis, an analysis of variance was employed to determine the differences between the four groups in amount of social contact or support. Means and standard deviations for the groups were:

(1) survived and predicted to survive--M=2.62, S.D. $=.57$

(2) survived but predicted to be institutionalized-$M=2.52$, S.D. $=.51$

(3) institutionalized but predicted to survive- $-M=2.62$, S.D. $=.60$ 
(4) institutionalized and predicted to be institutionalized-$M=2.41, S \cdot D .=.49$.

There were no significant differences between the groups on the social interaction score $(\mathrm{F}=1.54 ; \mathrm{p}=.2038)$. Based on statistical analysis, the hypothesis was not supported.

\section{Qualitative Analysis of Case studies}

In order to explore this further, case study analysis was done to determine the conditions surrounding individuals whose outcome group had not been predicted accurately. Within the study sample $(N=24)$, five had not fallen into their predicted outcome groups. Two people (Mrs. Haskins, in poor health, and Mrs. Roberts, with low cognitive status) were still living in the community at stage 2 . Three individuals who had scored higher on these measures, Mrs. Seltzer, Mrs. Morgan and Mrs. Hart, had entered nursing homes.

The cases of these five individuals are summarized in Figure 3. once again the case study analysis indicates some support for the hypothesis. Mrs. Haskins lived alone at Stage 1, but her son and daughter-in-law lived close by and provided support. For example, her son was present for the stage 1 interview and insisted on reading it before the interview took place. In addition, Mrs. Haskins' daughterin-law prepared all her meals for her. This support was strengthened when Mrs. Haskins' son and his family moved in with her. Her health remained poor but did not decline significantly. Thus, in the case of Mrs. Haskins, social supports were clearly a major factor in enabling her to remain in her own home. 
The presence of social supports were also important in the case of Mrs. Roberts. She had an extremely low cognitive status score, nearly two standard deviations below the mean. Her memory was poor and she seemed unable to do many things for herself (e.g., shopping, meal preparation). By the Stage 2 interview Mrs. Roberts had a housekeepex (who appeared to be her niece) who was living with her. Mrs. Roberts was still relatively socially isolated; she had no contact with her son, other relatives or friends, yet the presence of a housekeeper allowed her to continue living in her own home.

Those who entered nursing homes but were predicted to remain in the community had had a variety of experiences. Only the case of Mrs. Hart seemed related to social participation: Mrs. Hart was married at stage 1 but by stage 2 her husband had died. Mrs. Hart also had problems with her eyes and had various other physical problems. She stated that she did not want to live with relatives and that a friend of hers had lived in the facility and so she had chosen to enter the nursing home. In general, Mrs. Hart seemed to have poor relationships with her son and granddaughter. She said that her brother was ill and thus she rarely saw him. It also appeared that she had not maintained relationships with friends. It may, therefore, be argued that Mrs. Hart entered a nursing home largely due to the loss of an important social support, a support that was not compensated for through other social relationships.

The remaining cases of Mrs. Morgan and Mrs. Seltzer are clearly not related to social participation indicators. Mrs. Morgan's physical status declined dramatically and by stage 2 she was bedridden and 
dependent upon the nursing home staff for all personal care. Mrs. Morgan had a very good relationship with her sons and family. It is likely that this relationship was helpful in adapting to and coping with nursing home life, but it could not have prevented the need for such care.

In some ways, Mrs. Seltzer's experience was similar to that of Mrs. Morgan. Mrs. Seltzer and her husband were on a bus trip sponsored by a Senior Center. There was an accident and Mrs. Seltzer was hospitalized with a broken leg. She was later transferred to a nursing hame to recover and was eventually transferred to a home for the aged to live with her husband. It is clear that, in this case, institutionalization could not be prevented by the presence of strong social supports. However, as in the case of Mrs. Morgan, social supports appeared important in helping Mrs. Seltzer cope with the situation. In fact, being reunited with her husband appeared to be an important motivation in her recovery.

Summary. In sum, in three of the five cases where individuals did not fall into appropriate categories, the presence or absence of social supports seemed to be the deciding factors. This number of cases is clearly too small to be generalizable, but the cases do have serious implications for future research. First, there is a need to improve methods of collecting data in order that the quality of relationships can be accurately reflected and to accurately identify the social resources available to a person in case of loss. 
CHAPTER VI

DISCUSSION AND IMPLICATIONS OF THE STUDY

The results of this study raise many theoretical and methodological questions. In this chapter many of those questions regarding the self-concept in old age and the role of social supports in influencing the well-being of the elderly will be addressed.

Characteristics of the Self-Concept of older People

The results of the Tennessee Self-Concept Scale offer many interesting insights into the self-concepts of older people. At the same time, the findings raise many serious questions which clearly indicate the need for extensive, systematic, longitudinal research. The first finding of this study was that there was virtually no difference in mean self-concept scores between the institutionalized and commuity residing respondents. Secondly, standard deviations were significantly larger for many of the TSCS subscores. This indicates a diverse heterogeneous population.

An important issue, and one that cannot be adequately addressed in this thesis, is whether self-concepts in old age are similar to or different from the self-concepts found in those of younger age groups. Based on cross-sectional studies, there are clearly differences between age group responses to the TSCS. As mentioned before, older respondents seem to be part of a more heterogeneous group and their response patterns are more likely to show extreme differences from the norm 
group than other age groups.

This suggests another area of inquiry. As discussed earlier, results from many studies of self-concept have been contradictory. This may be due in part to the diversity of the aged population and/or to the fact that few of the studies used the same instruments to measure self-concept. Hoffer (1977) reviewed literature regarding self-esteem and concluded that the self-concept, or self-esteem, is multifaceted. Thus, the various scales that have been used in the past may reflect only one aspect of the self-concept. Results from this study show that while the total self-concept mean is positive, relative to the norm group, there are also areas of self-perception which are negative. With few exceptions, the respondents in this study had low identity and physical self-concept scores. It is also interesting to note that the average older person in this study was approximately 1.5 standard deviations above the norm group in moralethical self. Furthermore, moral-ethical self was the only scale where the variance of the older sample was smaller than the norm group variance.

The TSCS has other subscores which indicate that the pattern of self-perception in older people is different from the patterns found in younger persons. First, the majority of respondents (75\%) in this study had low self-criticism scores. According to the TSCS manual (Fitts, 1965), this indicates defensiveness and denial of negative traits. Rather than being indicative of maladjustment, however, it may well be that denial serves an important adaptive function in old age. Four of the six respondents with high self-criticism scores had low 
total self-concept scores (50\% of those in this category). The two with high self-criticism and high self-concept scores were both married and scored high on the well-being indicators. A second explanation of low self-criticism scores involves the specific items that make up this scale. It is possible that there are significant cohort differences between the norm group and those taking part in this study. Therefore, when the respondents indicated they never "put off 'til tomorrow what they could do today" or that they never "laugh at a dirty joke.", they may not be denying but may in fact be accurately describing their actual behavior--behavior grounded in the prevailing value system of their youth. Thus, those with high self-criticism scores may have negative self-concepts in part because they are not living up to their own standards or expectations, based again on an earlier value system.

Many of the respondents showed inconsistency both in their response to positive and negative items and from one area of selfperception to another. This too appears to be a common response pattern of older respondents. In this study, those with negative selfconcepts were more likely to be inconsistent in both areas ( 7 of 8 respondents) than those with positive self-concepts ( 1 of 12 ).

A question that arises here is whether or not the TSCS reflects important aspects of self-perception in old age. Butler and Lewis (1973) discuss the importance of Life Review as a means of coming to terms with one's life. Outcomes of the process include acceptance, satisfaction, or depression. This is somewhat similar to Erikson's (1959) developmental stage of integrity vs. despair. It would be 
interesting to determine whether or not those individuals with inconsistent responses were going through a life review process and had not yet come to terms the way they had spent their lives.

Findings from this and other studies using the TSCS seem to suggest that there are differences in self-concepts generally held by old people and those of younger age groups. A major question, however, is whether such differences are due to cohort effects or to ontogenetic change. There are a number of important differences in upbringing and experience between those in the study and those who took part in the development of the TSCS. At the same time these differences may occur as part of the aging process. Longitudinal research is required before any conclusions can be made.

Another important question, which is related to age differences, is whether or not and to what extent self-concepts remain stable or change over time. Coupled with this is the question of when and how the self-concept is formed. Role theory suggests that it is based upon i.teraction with significant others. The findings of this thesis suggest that this is true. There is strong evidence that a satisfying relationship with children or relatives is associated with a positive self-concept and that poor relationships are associated with negative self-concepts. Examination of the case studies suggest that the qualitative aspects of the social relationships of the respondents were well established and had not changed significantly over a period of several years. This suggests that the self-concepts may also remain fairly stable over time. However, with the evidence provided in this thesis, 
one cannot draw any conclusions. Additional research is clearly needed. Ideally, several cohorts should be followed over a period of from 30 to 40 years-from midale to old age. Information regarding self-concepts, relationships with others, significant changes occurring between periods of data collection, and behavior would be gathered every 10 years. By following two or more cohorts for 30 or more years (with three or more data collection points), one may identify both age and cohort effects and cohort specific age trends. This would allow researchers to determine (1) whether or not the self-concept changes with age and whether or not change is cohort-related or ontogenetic; (2) the relationship between various factors and the self-concept; and (3) the relationship between the self-concept and behavior (e.g., ability to adapt)

Prior to such an extensive effort, rigorous validation procedures would be required to assure that the measures used accurately reflect the self-concept of older and middle-aged persons.

Social Support Persons and Well-being of the Elderly The major issue to be discussed in this section concerns the utility of quantitative and qualitative measures of social participation. In testing the second hypothesis it was clear that the quantitative measures were inadequate. For the most part questions concerned frequency of contact, presence of children, and so forth, and, although respondents were asked how satisfied they were with their social relationships, very few indicated dissatisfaction even when case study material clearly indicated the presence of serious divisions and dis- 
satisfaction. This suggests that in a formal interview setting many older persons are reluctant to reveal unsatisfactory relationships or to volunteer information that is helpful to the researcher to understand the respondent's own unique experience.

Case study analysis indicated that in some cases the presence or absence of social support persons may prevent or lead to institutionalization. It is important to note that intervention by social support persons is not always possible due to many factors, mostly health status. Therefore, one cannot assume that entry into a nursing home means the absence of social supports or absence of caring relationships. Findings from this study merely suggest that in many cases this support can and does make a difference.

There are two important implications for further study. First, researchers must identify methods of collecting more accurate information concerning the qualitative aspects of social relationships. Second, researchers must be able to measure a person!s store of personal and social resources in order to identify which people are likely to be more vulnerable in case of death of spouse, acute or debilitating illness, etc.

From the results of this study, it appears that one useful method of collecting accurate data is the informal interview. This method can use structured questions and can be consistent, but it appears important to allow individuals to express themselves and to be encouraged to discuss at some length questions that are important to them. Other methods include questionning respondents about shared activities, pleasurable or unpleasant encounters, etc. 
The well-being indicators used at stage 1 represent the first step in developing measures of an individual's personal resources. These indicators represent a variety of conditions that contribute to an individual's ability to function. Methods of strengthening the social contact or social participation measure have been discussed. Several of the other measures also require some adjustment in order to improve their ability to predict the capability of older persons to survive and function in a satisfactory way. For example, the cognitive status indicator proved to be a valuable predictor of institutionalization; however, close examination of the case studies raise important questions concerning the accuracy of this measure. The measure was based upon interviewer observation and perception regarding interest in the interview, accuracy of information given, and level of alertness. In some cases the respondent was given a low cognitive status score at stage 1 that seemed contradictory to this status at Stage 2. Although it is possible that an individual's cognitive status could change in that time, it also seems likely that the individuals in question were simply not interested in the interview, were shy, found the interview unpleasant, or were thinking about other things. The cognitive status indicator may be a better measure of social interaction skills than of cognitive status per se. Also, these variables may be closely related in that low cognitive status may be accompanied by limited social graces/sklls. One might speculate that this measure was a useful predictor of institutionalization because individuals who were lacking in social skills were more susceptible to institutionalization. Therefore, in future studies concerning personal resources there needs 
to be more objective measures of cognitive status that will more accurately reflect an individual's intellectual capabilities.

The income information also seemed to contain errors or inconsistencies. It has been suggested that in future research respondents be given the interview schedule ahead of time so they can gather the necessary information prior to the interview. This would also help reduce the anxiety or stress involved in being part of a research study.

It would also be of interest to interview a number of significant others in order to learn of their perceptions of the resources available to the older person: Such information would provide important insight into similarities and/or differences between the older person's and the social support person's perception of the living condition of the older person.

Finally, there needs to be some system of weighting these indicators in order to establish the relative importance of each condition in predicting well-being. Similarly, studies need to be done to determine whether or not these factors interact with one another and, if so, the degree to which these interactions influence predictions of survival. The following hypotheses have been generated from this study and from the discussion in this chapter. First, it is hypothesized that older persons with emotionally satisfying social relationships will not develop negative self-concepts as a result of institutionalization. It appears from this study that institutionalization has a minimal impact upon self-concepts whereas social relationships are quite important. Second, much of the literature suggests that the way 
people view themselves remains fairly stable over time. Therefore, it is hypothesized that self-concept in middle age is an indicator of self-concept in old age. Similarly, from the case study analysis it appears that the qualitative aspects of social relationships remain stable over time. Therefore, it is hypothesized that self-concepts in old age can be predicted by the nature of social relationships in middle age. Finally, the issue of whether differences in selfconcept found between age groups is due to ontological causes or to cohort differences needs further study. A hypothesis to be tested in examining this issue is that older persons exhibit a different pattern of self-concept than younger persons.

In summary, this thesis has explored the self-concepts of older persons and the relationship of social support persons to self-concept and to survival. More research is clearly needed, however, before any definitive conclusions can be reached. 


\section{BIBLTOGRAPHY}

Anderson, Nancy N. "Effects of Institutionalization on Self-Esteem." Journal of Gerontology, 1967, 22, pp. 313-317.

Anderson, Nancy N. "Institutionalization, Interaction and SelfConception in Aging." In Arnold M. Rose and Warren A. Peterson (Eds.), Older People and Their Social world. Philadelphia : F. A. Davis, 1965, pp. 245-257.

Atchley, Robert c. The Social Forces in Later Life. Belmont, Ca.: Wadsworth Publishing Co., 1972 .

Bell, Tony. "The Relationships Between Social Involvement and Feeling Old Among Residents in Homes for the Aged." Journal of Gerontology, 1967, 22, pp. 17-22.

Biddle, Bruce J. and Edwin I. Thomas. Role Theory: Concepts and Research. New York: John Wiley and Sons, Inc., 1966.

Bild, Bernice R. and Robert J. Havighurst. "Family and Social support." In Senior Citizens in Great Cities: The Case of Chicago, The Gerontologist. February 1976, 16 (Part II), pp. 63-69.

Blau, Zena Smith. Old Age in a Changing Society. New York: New viewpoints, 1973 .

Blau, Zena Smith. "Structural Constraints of Friendships in Old Age." In Clyde B. Vedder (Ed.), Gerontology: A Book of Readings. Springfield, Ill.: Charles C. Thomas Publishing Co., 1963, pp. 66-78.

Brim, Orville G. Jr. "Adult Socialization." In Robert Atchley and Mildred Seltzer (Eds.), The Sociology of Aging: Selected Readings. Belmont, Ca.: Wadsworth Publishing Co., 1976, Pp. 81-94.

Brody, Elaine. Long-term Care of Older People. New York: Human Sciences Press, 1977.

Butler, Robert N. and Myrna I. Lewis. Aging and Mental Health: Positive Psychosocial Approaches. St. Iouis: C. V. Mosby Co., 1973. 
Cavan, Ruth Shonle. "Self and Role in Adjustment During Old Age." In Clyde B. Veddex (Ed.), Gerontology: A Book of Readings. Springfield, Ill.: Charles C. Thomas Publishing Co., 1963, pp. $122-130^{\circ}$.

Chapman, Nancy J. and Marie Beaudet-Walters. "Housing and Neighborhood Environments." In John E. O'Brien and Renee Alexandef (Eds.), A Iongitudinal Study of a High Risk Urban Elderly Population. Portland, Ore.: Institute on Aging, 1978.

Chiriboga, David and Majda Thurnher. "Concept of Self." In Marjorie Fiske Lowenthal, Majda Thurnher, and David Chiriboga (Eds.), Four Stages of Life. San Francisco: Jossey-Bass Publishers, 1975, pp. 62-83.

Coe, Rodney M. "Self-Conception and Institutionalization." In Arnold M. Rose and Warren A. Peterson (Eds.), Older People and Their Social World. Philadelphia: F. A. Davis Co., 1965.

Fitts, William H. Manual: Tennessee Self-Concept Scale. Nashville: Counselor Recordings and Tests, 1965.

Goode, William H. and Paul K. Hatt. Methods in Social Research. New York: McGraw-Hill Book Co., 1952 .

Gordon, Gerald. Role Theory and Illness: A Sociological Perspective. New Haven: College and University Press, 1966.

Grant, Carmet Rita Hill. Age Differences in Self-Concept From Early Adulthood Through old Age. Unpublished doctoral dissertation, University of Nebraska, 1967.

Havighurst, Robert J. "Successful..Aging." In Clyde B. Vedder (Ed.), ferontology: A Book of Readings. Springfield, Ill.: Charles C. Thomas Publishers, 1963, pp. 66-78.

Hawkinson, William P. "Wish, Expectancy and Practice in the Interaction of Generations." In Arnold M. Rose and Warren A. Peterson (Eds.), Older Persons and. Their Social World.

Philadelphia: F. A. Davis Co., 1965, pp. 181-190.

Heiss, Jerold. "An Introduction to the Elements of Role Theory." In Jerold Heiss (Ed.), Family Roles and Interaction: An Anthology. Chicago: Rand McNally and Co., 1968.

Hoffer, Vernon. "Self-Esteem: Review of the Iiterature." Working paper, Institute on Aging, 1977.

Johnson, Elizabeth S. and Barbara J. Bursk. "Relationships Between the Elderly and Their Adult Children." The Gerontologist, 1977, 17 (1) ; pp. 90-96. 
Kalish, Richard A. Late Adulthood: Perspectives on Human Development. Berkeley: Wadsworth Publishing Co., 1975.

Kaplan, Jerome. "New Theories Affecting Geriatric Social Institutions." In Clyde B. Vedder (Ed.), Gerontology: A Book of Readings. Springfield, Ill.: Charles C. Thomas publishers, 1963, pp. $402-410$.

Kramer, Charles H. and Jeanette R. Kramer. Basic Principles of LongTerm Patient Care. Springfield, Ill.: Charles C. Thomas Publishers, 1976 .

Linton, Ralph. "Status and Role" (1936). In Talcott Parsons, Edward Shils, Kasper D. Naegele, Jesse R. Pitts (Eds.), Theories of Society, Vol. 1. New York: Free Press of Glencoe, 1962, pp. 202-208.

Lowenthal, Marjorie Fiske and Clayton Haven. "Interaction and Adaptation: Intimacy as.a Critical variable." In Bernice Neugarten (Ed.), Middle Age and Aging. Chicago: University of Chicago Press; 1968.

Mead, George Herbert. "Play, the Game and the Generalized other." In Walter L. Wallace (Ed.), Sociological Theory: An Introduction. Chicago: Aldine Publishing Co., 1969, 228-233.

Mead, George Herbert. "The I and the Me" (1934). In Talcott Parsons, Edward Shils, Kasper D. Naegele, Jesse R. Pitts (Eds.), Theories of Society, Vol. 1. New York: Free Press of Glencoe, 1962, pp. 163-168.

Moen, Elizabeth W. and Thomas H. Moen. "What Do the Elderly Want?" Report to the Oregon State Program on Aging and The Gerontological Society, 1977 .

Neugarten, Bernice. "Continuities and Discontinuities of Psychological Issues in Adult Life.". In .D. C. Charles and William R. Crift (Eds.), Readings in Psychological Development Through Life. New York: Holt, Rinehart and Winston, Inc., 1973.

O'Brien, John E. and Renee Alexander (Eds.) A Longitudinal Study of a High Risk Urban Elderly Population. Portland, Ore.: Institute on Aging, 1978 .

O'Brien, John E. and Donna L. Wagner. "Primary Associations: A Conceptual Framework for Analyzing Behavior." Working paper, Portland, Ore.: Institute on Aging, 1975.

Payne, Raymond. "The Sociology of Aging: Some Theoretical Approaches to the sociology of Aging.".. In Clyde B. Vedder (Ed.), Gerontology: A Book of Readings. Springfield, Ill.: Charles C. Thomas publishers, 1963, pp. 49-56. 
Peters, George R. "Self-Conceptions of the Aged, Age Identification and Aging." The Gerontologist, winter 1971, Part II, pp 69-73.

Phillips, Bernard S. "A Role Theory Approach to Adjustment in old Age." In Clyde B. Vedder (Ed.), Gerontology: A Book of Readings. Springfield, Ill.: Charles C. Thomas Publishers, 1963, pp. 56-66.

Pihlblad, C. Terence and Robert L. MCNamara. "Social Adjustment of Elderly People in Three Small Towns." In Annold M. Rose and Warren A. Peterson (Eds.), Older Peopld and Their Social World. Philadelphia: F. A. Davis Co., 1965, pp. 49-73.

Postem, Leonard.J. "Reminiscing, Time Orientation, and Self-Concept in Aged Men." Unpublished doctoral dissertation, Michiagn state University, 1970.

Rose, Arnold M. "Group Consciousness Among the Aging." In Arnold M. Rose and warren A. Peterson (Eds.), Older People and Their social World. Philadelphia: F. A. Davis Co., 1965, pp. 3-16.

Rose, Arnold M. "The Subculture of the Aging: A Framework for Research in Social Gerontology.". In Arnold M. Rose and warren $A$. Peterson (Eds.), older People and Their Social World. Philadelphia: F. A. Davis Co., 1965, pp. 19-36.

Rosow, Irving. Socialization to old Age. Berkeley: University of California Press, 1974.

Schaie, K. Warner and Joyce P. Schaie. "Clinical Assessment and Aging." In J. E. Birren and K. W. Schaie (Eds.), Handbook of the Psychology of Aging. New York: Van Nostrand Reinhold Co., 1977 .

Schul: Richard. "Effects of Control and Predictability on the Physical and Psychological Well-Being of the Institutionalized Aged." Journal of Personality and Social Psychology, 1976 , $33(5)$, pp. 563-573.

Selltiz, Claire, Marie Jahoda, Morton Deutsch and stuart W. Cook. Research Methods in Social Relations. New York: Holt, Rinehart and winston, 1959.

Shanas, Ethel, Peter Townsend, Dorothy Wedderburn, Henning Frus, Paul Milhoj and Jan Stenhouver. "The Psychology of Health." In Bernice Neugarten (Ed.), Middle Age and Aging. Chicago: University of Chicago Press, 1968, pp. 212-219.

Smith, Harold E. "Family Interaction Pattern of the Aged: A Review." In Arnold M. Rose and Warren A. Peterson (Eds.), older People and Their Social World. Philadelphia: F. A. Davis Co., 1965, pp. 143-161. 
Thomas, Edwin J. "Problems of Disability from the Perspective of Role Theory." In Paul H. Glasser and Lois N. Glasser (Eds.), Families in Crisis. New York: Harper and Row, 1970, pp. 250-272.

Thompson, Warren. Correlates of the Self Concept. Nashville: Dede wallace Center, studies of the self concept, Counselor Recordings and Tests, June 1972.

Thornton, Russell and Peter M. Nardi. "The Dynamics of Role Acquisition." American Journal of Sociology, 1975, 80(4), pp. 870-885.

Tobin, Sheldon S. and Mortan A. Lieberman. Last Home for the Aged. San Francisco: Jossey-Bass, 1976.

Turner, Barbara F., Sheldon S. Tobin, Morton A. Lieberman. "Personality Traits as Preditors of Institutional Adaptation Among the Aged." Journal of Gerontology, 1972, 27(1), pp. 61-68.

Turner, Jonathan. Structure of Sociological Theory. Homewood, Ill.: The Dorsey Press, 1974.

Videbeck, Richard and Alan B. Knox. "Alternative Participatory Responses to Aging." In Arnold.M. Rose and Warren A. Peterson (Eds.), Older People and Their Social world. Philadelphia: F. A. Davis, 1965, pp. 37-48.

Wagner, Donna and Diana White. "The Use of Survey Data and Case Histories in Gerontological Research: A Call for the Revision of Methodological Approaches." Paper presented at the Annual Meeting of the Gerontological Society, Dallas, Texas; 1978.

Ward, Russell A. "The Impact of Subjective Age and stigma on Older Persons." Albany, N.Y.: Department of Sociology, State University of New York, 1971.

Wershaw, H. J. "The Four Percent Fallacy: Some Further Evidence and Policy Implications." The Gerontologist, 1976, 16, pp. 52-55.

Whitelaw, Nancy and Barbara stewart. "Testing a Model of Late Iife Decline: Predicting Four Late Life Outcomes from Nine Measures of Well-Being." .In.John .E. O'Brien and Renee Alexander (Eds.), A Longitudinal study of a High Risk Urban Elderly Population. Portland, Ore.: Institute on Aging, 1978.

Williams, Richard $\mathrm{H}$. "Changing status, Roles and Relationships." In Clark Tibbits (Ed.), Handbook of Social Gerontology. Chicago: University of Chicago, 1960, pp. 92-119. 


\section{APFENDIX I}

\section{WELL-BEING INDICATORS}

Medical Health Status: 5 items indicating self-perceived condition of health, amount of time bedridden or in hospital during the past year, use of a visiting nurse, and observer's rating of disabilities.

Cognitive status: 3 items including observer ratings of the older person's degree of alertness, lack of confusion and level of interest in the interview.

Daily Functioning: 5 items covering personal mobility, use of prosthesis, physical therapy, meals program, and housework help.

Activities: 7 items covering the extent to which the older person is confined to home, how recently the person has gone to a grocery, post office, bank, restaurant, or church, and the means of transportation a person usually uses.

Social Contacts: 8 items reflecting having, living near, and interacting with children, the numbers of one's confidants, recency of talking with a neighbor, relative, friend, or other person.

Iife Satisfaction: 4 items including aspects of life satisfaction such as the extent to which one is as happy now as when young and the extent to which one expects interesting things to happen.

Income: 11 items covering sources of financial support, subjective perception of current financial situation compared to others and to self in earlier years.

Housing: 4 items reflecting the existence of a kitchen and the number of rooms in one's housing unit as well as observer ratings of the general condition of the housing unit and its furnishings. 
APPENDIX II

STAGE I QUESTIONNAIRE

1. Generally speaking, would you say your health is good, fair or poor for your age?

2. How does your health or physical condition affect your ability to leave your home?

3.A.Do you have any living children? If yes, How Many?

B.If any living children:

How many of your children (Does your child)...

Live here with you?

Live 10 minuts away?

Live elsewhere in the city, county, or metropolitan area?

Live in some other part of Oregon?

Live in another state, and not in the same metropolitan area?

Live in another country?

Or, don't you know where they (s/he) live(s)?

C.Do you have any grandchildren?

4.A.Is there someone you can talk with about anything that really bnthers you or is important to you, or don't have anybody like that?

B. If yes: about how many people are there that you'd feel free to talk over very personal matters with?

5.A.When was the last time you talked in person with:

a neighbor?

children or grandchildren?

another relative?

some friend or acquaintance who was not one of your neighbors?

someone else besides a friend, relative or neighbor?

B.When was the last time you spoke to anyone on the telephone? 
6. Do you agree or disagree (strongly or somewhat) with the following:

A. I am just as happy as when I was younger.

B.I expect some interesting and pleasant things to happen to me in the future.

C.I would not change my past life even if I could.

D.As I grow older, things seem better than I thought they would be. 


\section{APPENDIX III}

STAGE 2 QUESTIONNAIRE

Part I - Institutionalized Elderly

1. How long have you lived in this nursing home?

2. Do you think this nursing home is a good place to live?

3. How satisfied are you with this nursing home?

4. What do you think is the most important improvement that could be made in this nursing home?

5. What influenced your decision to move here?

6.A.Do you have plans to move from here in the near future?

B.If yes: Have you chosen a place to move?

Where?

Why did you decide to move?

7. Do the people who live here often visit with one another?

8. How satisfied are you with your relationships with other residents?

9. $r^{m}$ zt would make it better?

Part II - Community Residing Elderly

1. Do you think this neighborhood is a good place for older people to live?

2. How satisfied are you with this neighborhood?

3. What do you think is the most important improvement that could be made in this neighborhood?

4. What influenced your decision to move here? 
5.A.Do you have plans to move from this (apartment/house) in the near future?

B.If yes: Have you chosen a place to move?

Where?

Why did you decide to move?

6. Do the people who live around you (neighbors) often visit with one another?

7. All things considered, how satisfied would you say you are with your relationships with neighbors?

8. What would make it better?

Part III - Institutionalized and Community Residing Elderly

1. Generally speaking, would you say that your health is good, fair, or poor for your age?

2. How often would you say you call someone (like a friend, relative, neighbor, etc.) just to talk?

3. A.Is there someone you could call day or night if you needed help or needed someone to talk to?

B.If yes: Who might that be?

4. In general, how important is your relationship to your family?

5. How many living children do you have?

6. $\quad \forall:$ on was the last time you spoke in person to one of your children?

7. How often would you say you speak to your children?

8. How often do you visit or are you visited by your children?

9.* Have you seen your children more or less often since you have been in the nursing home?

10. All things considered, how satisfied are you with your relationship with your children at the present time?

11. What would make it better?

12. When was the last time you spoke in person to one of your friends?

13. How often would you say you speak to your friends (those not living in the nursing home)? 
14. How often do you visit or are you visited by your friends?

15.* Have you seen your friends more or less often since you have been in the nursing home?

16. All things considered, how satisfied are you with your relationships with your friends at the present time?

17. What would make it better?

18. When was the last time you spoke in person to one of your relatives (not a child)?

19. How often would you say you speak to your relatives?

20. How often do you visit or are you visited by your relatives?

$21 .{ }^{*}$ Have you seen your relatives more or less often since you have been in the nursing home?

22. All things considered, how satisfied are you with your relationships with your relatives at the present time?

23. What would make it better?

24. How important is it to have new and different activities from day to day?

25. How important is it to have similar activities from day to day?

26. What types of activities do you usually participate in?

27. Overall, how happy would you say you are with your activities?

28. What things would improve your activities?

*Note: The indicated questions were addressed only to the institutionalized respondents. 
1. I have a healthy body

2. I am an attractive person

3. I consider myself a sloppy person

4. I am a decent person

5. I am an honest person

6. I am a bad person

7. I am a cheerful person

8. I am a calm and easy going person

9. I am a nobody

10. I have a family that would always help me in any kind of trouble

11. I am a member of a happy family

12. My friends have confidence in me

13. I am a friendly person

14. I am popular with men

15. I am not interested in what other people do

16. I do not always tell the truth

17. I get angry sometimes

18. I like to look nice and neat all the time

19. I am full of aches and pains

20. I am a sick person 
21. I am a religious person

22. I am a moral failure

23. I am a morally weak person

24. I have a lot of self-control

25. I am a hateful person

26. I am losing my mind

27. I am an important person to my friends and family

28. I am not loved by my family

29. I feel that my family doesn't trust me

30. I am popular with women

31. I am mad at the whole world

32. I am hard to be friendly with

33. Once in a while I think of things too bad to talk about

34. Sometimes when I am not feeling well, I am cross

35. I am neither too fat nor too thin

36. I like my looks just the way they are

37. I would like to change some parts of my body

38. I am satisfied with my moral behavior

39. I am satisfied with my relationship to God

40. I ought to ga to church more

41. I am satisfied to be just what I am

42. I am just as nice as I should be

43. I despise myself

44. I am satisfied with my family relationships

45. I understand my family as well as I should

46. I should trust my family more 
47. I as as sociable as I want to be

48. I try to please others, but I don't overdo it

49. I am no good at all from a social standpoint

50. I do not like everyone I know

51. Once in a while, I laugh at a dirty joke

52. I am neither too tall nor too short

53. I don't feel as well as I should

54. I should have more sex appeal

55. I am as religious as I want to be

56. I wish I could be more trustworthy

57. I shoulan't tell so many lies

58. I am as smart as I want to be

59. I am not the person I would like to be

60. I wish I didn't give up as easily as I do

61. I treated my parents as well as I should have

62. I am too sensitive to things my family say

63. I should love my family more

64. I am satisfied with the way I treat other people

65. I should be more polite to others

66. I ought to get along better with other people

67. I gossip a little at times

68. At times I feel like swearing

69. I take good care of myself physically

70. I try to be careful about my appearance

71. I often act like I am "all thumbs"

72. I am true to my religion in my everyday life 
73. I try to change when I know I'm doing things that are wrong

74. I sometimes do very bad things

75. I can always take care of myself in any situation

76. I take the blame for things without getting mad

77. I do things without thinking about them first

78. I try to play fair with my friends and family

79. I take a real interest in my family

80. I gave in to my parents

81. I try to understand the other fellow's point of view

82. I get along well with other people

83. I do not forgive others easily

84. I would rather win than lose in a game

85. I feel good most of the time

86. I do poorly in sports and games

87. I am a poor sleeper

88. I do what is right most of the time

89. I sometimes use unfair means to get ahead

90. I have trouble doing the things that are right

91. I solve my problems quite easily

92. I change my mind a lot

93. I try to run away from my problems

94. I do my share of work at home

95. I quarrel with my family

96. I do not act like my family thinks I should

97. I see good points in all the people I meet

98. I do not feel at ease with other people 
99. I find it hard to talk with strangers

100. Once in a while I put off until tomorrow what I ought to do today 


\section{APPENDIX V}

\section{SUBJECT CASE STUDIES}

\section{Mrs. Goodman - Low Self-Concept}

Mrs. Goodman, age 79, was living in a high-rise for low income elderly when first interviewed. Her housing score (2.25) was low for both community and nursing home respondents. She described her health as poor. She had spent 13 nights in the hospital in the past year and could only get out of her apartment with help. She got up every day but did not always dress. She said that her health interfered with activities. As an example, she said that she would like to go to a show but that she did not feel like it. She also said that if she had more money she would "take care of her health." Mrs. Goodman's medical status score $(2.25)$ was lower than that of others later institutionalized but the daily functioning score (2.75) was higher and similar to the community group mean score. Activity (1.99) was much like that of others in the institutionalized group.

Mrs. Goodman's social score was high (2.75) compared to mean scores of both groups. Mrs. Goodman had four children, one of whom lived in the metropolitan area. She had one confidant and in the week prior to the interview had talked in person with a friend, neighbor, and other person. She had also used the telephone. It had been six months since she had seen one of her children or other relatives. Mrs. Goodman's cognitive score was 2.67, falling between the 
nursing home and community group scores.

Mrs. Goodman felt that her level of living was about the same as others her age, but worse than it had been a year or 10 years ago. Her income score $(2.09)$ was quite a bit lower than the community or nursing home mean scores. She had been on welfare for some time, saying it "was the hardest thing I ever had to do" while at the same time saying "welfare has been so good to me." Mrs. Goodman strongly disagreed with the statements "I am just as happy as when I was younger" and "I expect some interesting and pleasant things to happen in the future." She disagreed somewhat with "I would not change my past even if I could" although she agreed somewhat with "As I grow older things seem better than I thought they would be."

The stage 2 interviews were quite extensive. Mrs. Goodman had been in a nursing home with about 90 residents for four months. The nursing home had two sections; one was new and attractive, while the other was old and appeared to be made up of an old house. Mrs. Goodman lived in the old section which was drab and uninviting. She noticed that the people who lived in the new part were better dressed than those in the older section, suggesting that welfare residents were segregated. Mrs. Goodman complained of the cold and of the "crazy people" who wandered into her room. She shared the room with two women who were bedridden and withdrawn and, thus, could not provide companionship.

Mrs. Goodman was an extremely unhappy woman. She described her health as poor although she was ambulatory, able to leave the facility and took care of most of her personal needs. She had come to the 
nursing home after being hospitalized. with a broken arm. She said, "They got me in here because they think I'm cuckoo in the head." At the same time, in response to her welfare worker's apparent efforts at encouraging her to move out of the nursing home, she wondered "Why do they want to kick me out?"

The source of Mrs. Goodman's major anguish is her poor relationships with her children. "What the children did to me gets me down more than the nursing home." She feels that they took her money and her personal possessions. The problems date back several years. She had not spoken with her son for three years before her move to the nursing home, partially because of problems with her daughter-in-law, but also because of his efforts to put her in an insane asylum. He had come to see her after her move and they had quite an argument. She told the nursing home she did not want to see him anymore. She also had problems with her daughters. She had not been to one daughter's home for 10 years. Her oldest son is dead and she mentioned him often, saying "None of this would have happened if he were here. He was wonderful to me."

Mrs. Goodman's daughter-in-law (the wife of the dead son) is her most important source of support. From South Dakota, she was visiting other relatives in the Portland area. She had been visiting Mrs. Goodman and taking her out of the facility each week. Mrs. Goodman did not know how long the daughter-in-law would stay and did not know what she would do without her. Mrs. Goodman says that she sleeps well after visiting with her daughter-in-law and is able to forget her troubles. 
In many ways Mrs. Goodman described herself as generous and selfless. She said "I was liked by everyone" and talked about friends who told her how important she was to them. However, she has not maintained contact with friends because they live too far from the nursing home.

The troubles, hurt and bitterness are very close to Mrs. Goodman. After being widowed when her children were still dependent, she worked as a janitor to earn a living for them. She feels badly treated and unable to forgive. She feels she has been too trusting in most of her relationships. Furthermore, prayers seem hollow and, with her feelings toward her children, she can't go to church. Finally, she maintained that because "I can't forgive, I won't get to heaven."

All Mrs. Goodman's TSCS scores were lower than the mean scores of the nursing home sample. Her total self-concept score was more than two standard deviations below the mean. The lowest self-concept scores were in the areas of identity, physical self, family self and social self. The moral-ethical score was similar to that found in Fitts' norm group; but still far below the other respondents in this study. Other TSCS scores indicated a presence of denial, confusion, contradiction, and inconsistency in self-perception. Although the distribution scores indicated certainty in response, this score was less extreme than the mean score for nursing home respondents.

2. Mrs. Todd 1 - Low Self-Concept

At stage I Mrs. Todd, a widow, was suffering from a muscular

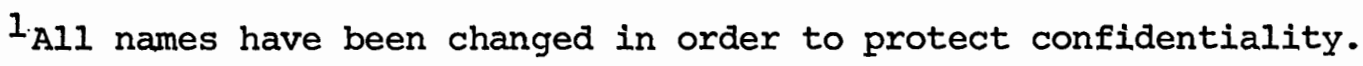


disease and was confined to home. Mrs. Todd rated her health as fair and in the past year had spent a total of three weeks in the hospital and most of the time in bed. Her poor health was reflected in the life space scores on medical status (2.25) and activities (1.43) which were lower than means for both the nursing home and community sample. Her poor health was also reflected in daily functioning (2.75) which was below the mean of the community group. 1

Mrs. Todd's social score was also quite low (1.50). She lived with her mother, who did her banking for her, and in the week before the interview had spoken with people on the telephone. It had been more than a month, however, since Mrs. Todd had spoken in person with a friend and more than a year since she had been to a grocery store, bank, church, post office, or had spoken with a neighbor. Mrs. Todd's cognitive status score was high (3.00), higher than the means for both nursing home and community respondents. Mrs. Todd was interested in the interview and the interviewer was quite certain of the accuracy of her responses.

Mrs. Todd's housing score (3.75) was higher than the mean scores for both groups. She had been Iiving in her home for 46 years. Income (2.73) was higher than that of many community respondents but lower than the mean score for nursing home respondents. Mrs. Todd felt that her level of living was worse than others her age. It was also worse than it had been 10 years earlier but was about the same as it had been a year before. Mrs. Todd and her mother had some people helping with housework. This had been arranged by a coordinator at a hospital Mrs.

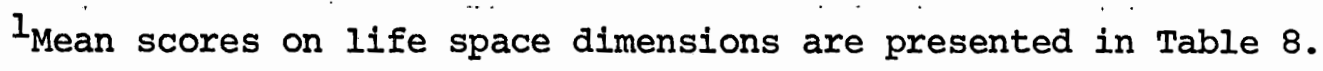


Todd's mother had been in.

Mrs. Todd strongly disagreed with the statements "I am just as happy as when I was younger" and "As I grow older things seem better than I thought they would be." She disagreed somewhat with "I would not change my past life even if I could." She agreed strongly with "I expect some interesting and pleasant things to happen to me in the future."

In the stage 2 interview, Mrs. Todd said that she was very satisfied with her housing arrangement. She had lived in the neighborhood nearly 50 years and felt that it had not changed very much. She liked the neighborhood because it was quiet and respectable.

Mrs. Todd said that her health was poor and that she remained confined to home and spent most of her time in bed. At the same time she said that she had had no health problems in the last four months and that it had been more than 10 years since she had seen a doctor. Mrs. Todd used almost no services although at one time she had used the Visiting Nurse Association and meals on wheels. She also said that transportation services had poor drivers. She was currently using homemaker services.

In terms of social participation, Mrs. Todd indicated that she called people to talk less than once a month. She said she could call the firefighters anytime, day or night, if she needed help. She said that there was no one she could talk to about anything that bothered her.

Mrs. Todd said that she did not know whether or not neighbors visited with one another. She was visited by neighbors about once a 
year and felt neutral in terms of her relationships with them.

Mrs. Todd said that family relationships were not too important. She had one living sibling she had not seen for more than a year. She said that she was somewhat dissatisfied with her relationships with relatives. Mrs. Todd had seen a friend within the last month and said she saw them about once every six months. She said she was neutral in terms of satisfaction with relationships with them. However, she agreed strongly with the statement "What is lacking in my life today is the old kind of friendship that lasted a lifetime."

During the TSCS portion of the stage 2 interview Mrs. Todd was in bed. She seemed very eager to take paxt in the interview. Often she appeared angry, saying "Friends., I'll tell you about friends!" She indicated that she has learned the hard way not to care what people care or think. She said that she did not care about others, but did say that she had friends. She seemed quite proud of her mind. Her room and bed were full of books and magazines. A few days before the interview Mrs. Todd's relatives had visited; she had a map and was following their travels back to California. She described her control over her life, with a discussion of having her house painted and having the check ready for the painter, to be given as soon as he completed the job to her satisfaction.

Mrs. Todd answered the TSCS questions quickly. She seemed unhappy in some ways. To the statement "I am popular with men" she responded "Shove them." To "My friends have confidence in me" she said, "I don't give a damn, to hell with friends." To "I am mad at the whole world" she said, "Just part of it." She asked to skip "I am Just 
as nice as I should be" and felt that "Once in a while I laugh at a dirty joke" was a "dumb question." Finally, to "I can always take care of myself in any situation" she said, "You can't do that! Anyone who says yes is nuts:"

As I was leaving, Mrs. Todd got out of bed and with her walker, walked me to the door. She said that she was helping me get a college education and that I should "tell those damn kids what I say--to get through life you need a positive mind and strong guts."

Mrs. Todd's TSCS scores seemed to reflect much of her anger and apparent unhappiness. Her total self-concept score (292) was quite low-mo standard deviations below the mean. Row scores (the internal frame of reference) were also quite low, particularly the identity, or "What I am", indicator. The self-satisfaction score was also quite low. Other extremely low scores included the physical self, social. self, and the family self. Her perception of her behavior and her personal self were very similar to the nom group, but below the scores of other respondents in this study. The only self-concept score above the norm and similar to other respondents was the moral-ethical score.

Unlike the others, Mrs. Todd's self-criticism score was quite high, indicating "a normal, healthy openness and capacity for self criticism" (Fitts, 1965:2). The net conflict score was low but the total conflict score was high. This is interpreted as conflict, contradiction, and confusion in self perception. Variability scores were extremely high, indicating little unity or integration-ma compartmentalized view of herself. Finally, distribution scores were high, 
reflecting the certainty with which Mrs. Todd answered questions.

\section{Mrs. Shannon - Low Self-Concept}

Mrs. Shannon was a widow with no chilaren. When first interviewed she described herself, at age 82 , as being in fair health compared to others her age, although she had spent six nights in the hospital in the past year. She reported that she was able to go out alone and, in the week prior to the interview, she had been to the grocery store and arug store. The interviewer indicated that Mrs. Shannon had a number of health problems which included diabetes, a hernia, and arthritis. The arthritis was quite severe. Mrs. Shannon was able to walk to the store but because of the arthritis she returned home in a taxi. Mrs. Shannon's medical status score was 2.50, similar to that of others who eventually entered a nursing home. Her daily functioning score (2.75) fell between the means of the two groups and her activities score (2.57) was much higher than both.

The social contact score $(2.50)$ was similar to the mean score of those later institutionalized. In the week prior to the interview Mrs. Shannon said she had spoken in person with neighbors, relatives, friends and others. Mrs. Shannon said that there were people she could discuss very personal matters with.

Mrs. Shannon had lived in her home for 30 years. The interviewer indicated that the house was in poor condition and that Mrs. Shannon "lived with about elght cats." Her housing score was quite low (2.00), far below the means of both groups. Mrs, Shannon was not enthusiastic about the interview but was willing to take part. Her cognitive status score (2.67) was higher than the mean of institutionalized respondents. 
Mrs. Shannon felt that her level of living was about the same as others. She felt however that she was worse off than she had been 10 years ago, although her level of living had not changed in the past year. She had not asked for welfare and said she would dislike doing so but indicated she would do so if she had to. Mrs. Shannon's income score (2.73) indicated that her financial situation was similar to that of community respondents and lower than other institutionalized individuals. Mrs. Shannon agreed somewhat with the statements "I'm just as happy as when I was younger" and "as I grow older, things seem better than I thought they would be." She did "expect some interesting and pleasant things to happen to me in the future" and she somewhat agreed that "I would not change my past life even if I could." Mrs. Shannon had used very few services. She had hired a neighbor girl to do housework and had called a Senior Center to have some trash moved away. In short, when first interviewed Mrs. Shannon appeared to be an independent and self-sufficient person in spite of physical ailments and worries about her neighborhood. She reported having friends and did not appear to be socially isolated.

When interviewed the second time Mrs, Shannon was living in a home for the aged. She had been there for three months. Before that time she had been in a nursing home, convalescing from a broken hip. She said that the home for the aged was "wonderful compared to where I was." She said that the cooking was better, that it was cheaper and that she had "a little more privilege." She said that in the nursing home she was often made to "feel naughty." At this interview Mrs. Shannon felt that "outside arthritis" her 
health was good for her age. She appeared to have maintained previous friends. In fact, she said that she has seen her friends more often since being in the nursing home. She called her friends daily and felt that one friend in particular, an old neighbor, was someone she could call day or night. She had been shopping with hef friend that day and had purchased clothes from a thrift shop. (She also had a number of wigs which she modeled at the conclusion of the interview.)

Mrs. Shannon indicated that the people in the Home did not visit with one another very often and she was neither satisfied nor dissatisfied with her relationships with them.

Mrs. Shannon had no living children but she did have a niece that she saw fairly regularly-monce or twice a month, more often than before institutionalization. The relationship with her relatives is somewhat unsatisfactory. She expressed strong dislike of her niece's husband and said that she had trusted them too much and that she "could get along without them pretty well." She said that the husband had sold her home without her permission so that she had no choice but to live in a home for the aged. She also said that her niece and her husband didn't do much for her. She is hard of hearing but they have not helped her find a hearing aid. She also needs dentures because, "I think the nurses [at the nursing home] stole them."

Mrs. Shannon's TSCS total self-concept score was low, -.83 standard deviations from the mean. Her lowest self-concept score was family self, followed closely by identity and personal self-concept. Her low physical score was close to the mean score for institutionalized respondents. Her highest scores were in the areas of moral- 
ethical and social self. The latter was much higher than the mean score.

Mrs. Shannon's self-criticism score was much higher than most respondents, indicating a healthy openness to self-criticism. Her. conflict scores and variability scores were high, suggesting inconsistency and a lack of integration of the various components of the self. Mrs. Shannon's distribution scores showed certainty in response, but she was more likely than any of the others to use the "partly true and partly false" category.

\section{Mrs. Sanders - Low Self-Concept}

When first interviewed Mrs. Sanders, 85, was. confined to her home. Although she described her health as being fair, in the past year she had spent nearly a month in the hospital and several days in bed. This is reflected by the low scores on medical status (1.80), daily functioning (1.25), and activities (1.00). Mrs. Sanders was using a number of services that had been arranged by friends. These incli ?ed use of a lawyer, physical therapist, someone to do housework, a visiting nurse, someone to do shopping, meals on wheels, and the use of a walker. It had been nearly a year since she herself had been to the store or to the bank. She had lived in her apartment for 13 years. The interviewer indicated that it was in good condition (housing score $3.25)$.

Mrs. Sanders' income was lower than others in the study. She described her level of living as "about the same as others her age" and felt that she was in worse circumstances than 10 years ago. She had a child in the metropolitan area and reported having one confidant. 
Mrs: Sanders' social contact score was high (2.75). In the week prior to the interview she had spoken in person with neighbors, friends and others, and she had called someone on the telephone. In the previous month she talked in person with her daughter and other relatives.

Mrs. Sanders' cognitive score was 2.67, falling between the mean scores of the nursing home and community samples. Mrs. Sanders agreed somewhat that as she grew older things seemed better than she thought they would be. She somewhat disagreed with the statements "I would not change my past life even if I could" and "I am just as happy as when I was younger." She strongly disagreed with the statement "I expect some interesting and pleasant things to happen to me in the future.

Shortly after this interview Mrs. Sanders entered a nursing home, an 80-bed intermediate care facility. Evidently her health and capability for independent living had deteriorated. She said that a social worker who was "so good" went to many places and selected the home she eventually entered. At the time of the stage 2 interview, Mrs. Sanders had been in the nursing home for a little more than two years. She shared a room and telephone with a woman who had become a good friend. Mrs. Sanders' bed was by the window which was decorated by dozens of plants. She described many of the plants, telling the kinds and who had given them to her. Many were hanging by macrame hangers that she herself had made. She had learned macrame in the nursing home and was now making and selling plant hangers. One of the nursing home staff bought the materials for her. Mrs. Sanders was also busy in other ways. On the first visit she was talking with her daughter on the 
phone and another afternoon she was on her way to a painting class that "she wouldn't miss for the world." She and her roommate also had visitors dropping in and both seemed to be favorites with the staff. Mrs. Sanders said that the nursing home was a good place to live and that except for the food she was very satisfied. She had no plans to move. Friends in the nursing home seemed important.' She said that there was no one to call day or night, however, if she needed help or needed to talk with someone because "all my friends are about my age and really couldn't help." At the same time however she identified her roommate as a confidante and felt very satisfied with her relationships with other residents. She said that she and her roommate had not been to the dining room for meals lately because they had not felt well and that several residents had come by to see how they were.

other relationships were also important. Mrs. Sanders called her daughter every day. The daughter was growing older (she had been married 43 years) and was in very poor health; as a result, Mrs. Sanders had not spoken in person with her daughter for six months and said that she saw her less often since she had been in the nursing home. Similarly, many of her friends were unable to visit, but she kept in touch by phone on a weekly basis. Mrs. Sanders had been visited by relatives the sunday before the interview. She indicated that she saw them every three or four months, less often than she had before entering the nursing home. As with friend, Mrs. Sanders kept in touch with her relatives by phone. She reported being very satisfied with her relationships with children, relatives, and friends. Finally, Mrs. Sanders said it was very important to have new 
and different activities from day to day and somewhat important to have similar activities. She was very happy with her activities. She did not go to exercise, "I can't stand it," but she enjoyed macrame, plants, flowers and painting.

Mrs. Sanders laughed a lot through the interview. She was quite interested although she tired quickly and required two sessions. Mrs. Sanders' self-concept score was somewhat lower than others in the study (-.77 standard deviations from the mean). Her subscores were also low, but nearly identical to mean scores in the area of identity. She was below the mean (but not to the extreme as in the previous case histories) in the areas of self satisfaction, physical, personal, family and social self. She expressed high levels of selfconception in behavior and moral-ethical self. (These scores were nearly the same as the mean scores for the group.)

The self-criticism score was much higher than for other respondents, suggesting less denial and more openness to criticism. At the same time, the high conflict and variability scores indicated conflict, inconsistency and contradiction in self-concept. It is interesting to note that unlike most others Mrs. Sanders had a tendency to over-deny negative attributes.

\section{Mrs. Grogan - Iow Self-Concept}

Mrs. Grogan was originally from Germany. She left as a young woman. She described hunger and scarcity of money as among other things she had to endure. She came to this country and married a German widower. Her life with him seemed to be miserable; she was treated more as a servant than a wife. She left hin and later married 
a strawberry farmer. They had built a small home in which they lived about 20 years and shortly before he died they had been running a bowling alley with the aid of their daughter and son-in-law. Shortly before the stage I interview Mrs. Grogan sold her home to a neighbor (a lawyer working in a professional building next door). Their agreement was that Mrs. Grogan would stay there as long as she lived and he would pay her each month and pay the taxes. Mrs. Grogan's housing score was 2.25 , below that of other surviving respondents. In the Stage 1 interview, Mrs. Grogan, 78, described her health as good for her age. She had not been hospitalized nor had she spent any days in bed due to illness in the past year and she was able to get out alone. Her activity score (2.14) was higher than the nursing home group but below that of others living in the community. Both medical status (3.00) and daily functioning. scores (3.25) were much higher than both sample means.

Mrs. Grogan's social contact scores were also high (2.75). She had one child who lived 10 minutes away. She said that she had no confidants, although in the previous week Mrs. Grogan had visited in person with her daughter, friends and others (a person not a friend, neighbor, relative). She had also called someone on the phone. In the past month she had talked with relatives and neighbors. She had also been to a drugstore, post office and bank. It had been over a year since she had been to a grocery store because there weren't any close. Mrs. Grogan's daughter did her shopping.

Mrs. Grogan's cognitive score was 2.33 , lower than both sample means. Mrs. Grogan was apparently apathetic or disinterested in the 
interview.

Mrs. Grogan's income score was higher than the means of both sample groups. She felt her level of living was about the same as others her age and that it was better than it had been one year or 10 years aga. In terms of services received, she had had legal advice from the man who bought her house, she herself arranged to get glasses, and her daughter and grandson had helped with home repairs.

Mrs. Grogan somewhat disagreed with "I an just as happy as when I was younger" and "I expect some interesting and pleasant things to happen in the future." She agreed strongly that "I would not change my past life even if I could" and agreed somewhat that "as I grow older things seem better than I thought they would be."

In the stage 2, part 1 interview, Mrs. Grogan indicated that she was satisfied with her neighborhood and that it was a good place to live. A new shopping center had been built across the street to replace one that had burned down. However, they had not built a grocery store. She said that although people in her neighborhood often visited one another they never visited her. She said that she spoke to neighbors weekly and that she was very satisfied with her relationship with them.

Mrs. Grogan indicated that she was thinking about moving, although she had not chosen a place. She said that her health was fair (compared to "good". two years earlier) and that she was able to get out alone. Although she lives within two blocks of a large, active Senior Center, she does not attend or use any. kind of service. Mirs. Grogan did say that there were people, probably her 
daughter, that she could call day or night if something bothered her. She indicated that she was very satisfied with relationships with her family, friends and relatives, seeing all of them on a weekly basis. She also reported being very happy with her activities-ogardening and television. She said that having both new and different activities every day was very important.

The interview using the TSCS contradicted many of the things Mrs. Grogan said in part 1 of the stage 2 interview. When approached for this portion of the interview her first comment was, "People always come to ask questions, but no one ever helps." For an hour and a half Mrs. Grogan described her many problems. An interview was not even attempted until a second visit.

Mrs. Grogan's family appears to be the source of many of her problems. Her daughter now lives on the other side of town; they have never been close. In response to the statement "I am a member of a happy family," she replied, "Deep in my heart...I don't know; there is a lot of trouble." To "I am satisfied with my family relationships," she said, "I have to make the best of it." Mrs. Grogan has often given her daughter money. She does not think highly of her son-in-law; their bowling alley did not do well and she apparently holds him responsible. He was in the hospital at the time of the interview and was a major source of concern. Mrs. Grogan had just given her daughter more money to help her get by. A 16 year old grandson was also a problem. He had received many traffic citations and was, in addition, missing a lot of school. Another grandson, however, seemed to be doing well in school. Mrs. Grogan had given both grandsons quite a bit 
of money over the years (to have teeth straightened, to help pay moving costs for the older one, etc.). In response to "I should love my family more" Mrs. Grogan said, "I love the kids but I don't like the grownups." To "I take a real interest in my familỵ" she replied, "Too much."

Mrs. Grogan indicated that she kept to herself and that she gets along with other people "because I leave them alone." She mentioned a friend in the hospital with whon she had been unable to talk or visit. Finally, Mrs. Grogan's health seems to bother her saying, "age is against me." She was bothered with a hernia, high blood pressure, and arthritis.

In sum, Mrs. Grogan appeared to be an unhappy and lonely woman. She had very few friends. She had worked hard all her life. (She reported several instances of people cheating her husband while he was alive.) Mrs. Grogan was unhappy with her family, but had little else in her life.

Mrs. Grogan's total self-concept score was low (-.74 standard deviations below the mean). The lowest subcategories in self-perception were in the areas of identity, physical self, family self, and social self. She scored high in the areas of self-satisfaction and moral-ethical self. Perceptions of behavior and of personal-self were slightly below the mean scores of the other respondents in the sample. Other of Mrs. Grogan's TSCS scores indicated defensiveness, conflicting and inconsistent responses to various items, and a strong tendency to over-affirm positive attributes. As with many other respondents, Mrs. Grogan also exhibited a high degree of certainty in 
her responses.

\section{Mrs. Jones - Iow Self-Concept}

Mrs. Jones, 84, came to Portland 33 years ago. She grew up in Texas with 10 siblings, two of whom are still living. She lived on a farm, picking cotton. Mrs. Jones worked as a practical nurse, She was married three times, the last time at age 46 . She was divorced eight years later.

The interviewer at atage 1 described Mrs. Jones as cooperative and willing to be interviewed, but not enthusiastic. The interviewer saw no signs of confusion and felt that Mrs. Jones enjoyed the interview. Her cognitive status score was very high.

At the stage 1 interview, Mrs. Jones rated her health as fair for her age. In the past year she had spent four nights in the hospital and for a total of 182 days had spent most of the time in bed. She did say that she was able to get out alone. Mrs. Jones' medical status (2.20), daily functioning (2.00), and activity (2.00) scores were ruite low--lower than both nuxsing home and community groups.

Mrs. Jones had two children. One of them lived with her and one was living in another state. She said that she had no confidants. The social contact score was 2.88 , above the mean of both groups. In the week prior to the interview, Mrs. Jones had talked in person with a neighbor, children, relatives, friends and others. She had also called someone on the telephone. In the previous month she had been to a grocery store and to church.

Mrs. Jones lived in a duplex in excellent condition; she owned it and had lived there for four years (housing score, 3.50). She had 
been in Oregon for 33 years. She felt her financial situation was about the same as others her age, although she was worse off than she had been both 1 and 10 years ago. She also said that she just managed to get by. Her income score indicated that she was worse financially than most community and nursing home respondents. With an extra \$150 a month Mrs. Jones indicated she would buy clothes, pay bills, and give more to the church. If she were to receive and extra $\$ 150$ a month she would "junp up and down" for joy and spend it for a "good cause." she also indicated she would buy something for her grandchildren, "who I adore," pay property tax, and buy better food.

Mrs. Jones strongly disagreed with the statement "I am just as happy as when I was younger," although she strongly disagreed with "I expect interesting and pleasant things to happen in the future", "I would not change my past life even if I could", and "As I get older things are better than I thought they would be."

Mrs. Jones had used a number of services, including: (1) physical therapy, arranged by her physician; (2) Loaves and Fishes, arranged by the Senior Center; and (3) a number of other services (e.g., getting new dentures, fixing up her house, talking with clergy), which Mrs. Jones arranged for herself.

One year later Mrs. Jones was interviewed again. 1 At this time she was no longer living with her children, saying that it was a bad idea to live with children. Instead, she was living with a friend, aged 66 .

Mrs. Jones reported being very satisfied with her current

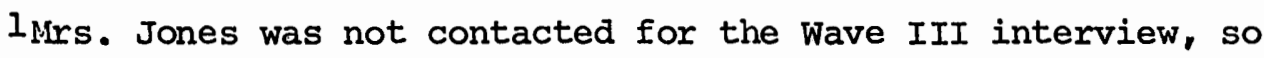
information from Wave II has been substituted. 
interests which included household chores, working with flowers, exercising, and watching television. She said that she did not participate in other activities and had a hard time getting out.

At this interview Mirs. Jones reported that she could call a church member day or night if she needed help. It had been more than six months since Mrs. Jones had spoken with one of her children in person although she had talked with one of them on the phone in the previous week. She had also spoken on the phone with neighbors and friends in the last week. Mrs. Jones saw relatives frequently, saying that they helped each other out two or three times a week. She indicated that if she were ill and needed help, or if she had to move, she would call on a friend. If she had trouble with social security she would ask her housemate for help. Mrs. Jones said that she was very satisfied with her relationships with family and friends.

Mrs. Jones rated her health as fair for her age, indicating that she had had health problems in the past four months and had seen a physician. However, in the past year she had not been in the hospital nor had she spent days in bed. The interviewer noted that Mrs. Jones had arthritis in her knees and that she was hard of hearing.

Mrs. Jones was interviewed a third time for the TSCS approximately one year later. The interview took two visits. Both times the house was full of children for whom Mrs. Jones' housemate babysat. During the first visit the interview was held in the living room with the television on and $\mathrm{a}$ dog and cat playing; there were also other people walking around. About half the interview was completed as Mrs. Jones appeared to tire. A second interview was thus required the 
following week. This time the interview was conducted on the front porch.

Mrs. Jones appeared interested in the interview and expressed a desire to see the results. Mrs. Jones had moved into her duplex when she was taking care of her sister, who lived in the other apartment, Mrs. Jones said that she had promised her mother that she would stay with her sister until one of them died. She felt it was important that she had done this. Mrs. Jones did say that she felt she had ruined her health taking care of her sister. who finally had been placed in a nursing home where she subsequently died. Mrs. Jones expressed gratitude for the case worker who had been "real helpful in finding a place close by." She also expressed some bitterness toward her niece who did not help at all.

Mrs. Jones also expressed disappointment and unhappiness with her relationship with her own children. She felt that she didn't get to see them enough and that they didn't call often enough. She also said that she did not approve of their lifestyles, that she was perhaps too old fashioned.

The profile of Mrs. Jones' TSCS scores indicated a pattern similar to the mean scores of the commity residing elderly. Mrs. Jones' total self-concept score was below that of the study sample mean ( -.50 standard deviations below the mean), but similar to the norm group mean. However, the $T / F$ ratio and net and total conflict scores were much higher, indicating that Mrs. Jones had a tendency to focus on what she is rather than on what she is not. The high net conflict scores indicate that responses to positive items conflicted 
with responses to negative items and that Mirs. Jones tended to overaffirm positive attributes. High total conflict scores indicated conflict and contradiction in self concept.

The row scores were similar to the norm group except for Row 3 (Behavior) which was lower. Column scores were also similar with the exception of the family self which was much lower and the social self which was higher than the norm group.

Variability scores were quite similar to the norm group, as were the distribution scores. D scores, particularly D5, were high, indicating certainty in what she said about herself.

\section{Mir. Hawkins - Low Self-Concept}

At Stage $1 \mathrm{Mr}$. Hawkins was living in a dirty, dark basement house in poor condition and with poor furnishings. His housing score was $1.75,-1.58$ standard deviations below the mean. He had lived there eight years. The interviewer described Mr. Hawkins' condition as follows. "Mr. Hawkins was on a bare, urine-soaked mattress. The stenc'. was overwhelming and the flies numerous. He was dirty and smelly and had dried blood on his chin from a fall a few days before." Mr. Hawkins had been bedridden approximately 10 months, following a stroke, and had coughing spells. His medical status score was 2.50 , however, which was not much lower than the mean of the institutionalized sample. Both daily functioning (1.75) and activities (1.43) scores were quite low--more than one standard deviation below the mean. It had been a year since he had been to a grocery store, restaurant, or drugstore. His cognitive status score (3.00) was nearly one standard deviation above the mean. 
In spite of his health and living conditions, Mr. Hawkins was cheerful and enthusiastic about the interview. He felt that his health was good for his age. Mr. Hawkins was separated from his wife, and had two children. In a later interview (Stage 2), Mr. Hawkins indicated that his children were retarded and had spent quite some time in insțitutions. Mr. Hawkins reported having ten confidants. He said that in the last week he had visited in person with neighbors, children and friends. He had also used his telephone. Mr. Hawkins' social contact score was 2.88 , which was high compared to others in the sample. However, in light of the stage 2 interview this score may not reflect Mr. Hawkins' actual status.

Mr. Hawkins felt that his level of living was better than that of most people his age. And, although he was worse financially than he had been ten years ago, his financial situation was about the same as the year before. His income score was 2.50 , one standard deviation above the mean. When asked what he'd do with an extra $\$ 50$ a month, Mr. Hawkins said that he didn't need the money, but that he would probably save it in case of sickness. With an extra \$150 a month Mr. Hawkins thought he would get a better apartment and give some of it to his children for their bank account. He repeated, however, that "I already got enough." He had received meals on wheels only three times; he discontinued them saying, "give them to someone who needs them." Mr. Hawkins said that his son did housework for him.

Mr. Hawkins agreed somewhat that "I am just as happy as when I was younger", "I would not change my past life even if I could", and "As I grow older things seem better than I thought they would be." He disagreed somewhat with the statement "I expect some interesting and 
pleasant things to happen to me in the future."

Two years later (stage 2), Mr. Hawkins was in a nursing home. When first approached about the interview he was involved in a card game with other residents and the activity director. He was very willing to be interviewed, although he at first confused the interviewer with the Activity Director.

Mr. Hawkins thought he had been in the nursing home for seven years. He thought it was a very poor place to live and he was very dissatisfied with it. He said that they had kept his rent rebate and that everything in general needed improvement. He reported that a physician at a nearby hospital had made him go to the home. When asked if he had plans to move, he said no, but "I would move if I could, any time, any day. I'd kill a man to go." This last was somewhat unconvincing--he seemed to use it to emphasize his dislike. There were some redeeming features. He liked the cook, who knew his name, but then he added that "the people [staff] up here, though, don't care if you eat or not." People in the nursing home visited a little with each other. In terms of his relationships with other residents, Mr. Hawkins was neutral saying, "I get along." He had no good friends and said that the nursing home was "like any community--some you fall for, some you don't." Mr. Hawkins was in a wheel chair and had no use of one arm. His speech was also somewhat difficult to understand. However, Mr. Hawkins felt that his health was good for his age. Although separated from his wife at stage 1, Mr. Hawkins apparently had maintained or renewed ties with his wife. He said that she was diabetic and in poor health, but that she took care of his finances 
and that he could call on her day or night. Mir. Hawkins felt that the priest who came to the nursing home was also someone he could talk to about anything that bothered him or was important.

Mr. Hawkins said that his relationship with his family was very important to him. He talked about his children, who lived with their mother. As indicated earlier, they were apparently mentally retarded. Mr. Hawkins was proud of the fact that they were now working and earning money. He said that his wife also took care of their finances. Mr. Hawkins had seen his children more often since he had been in the nursing home; indeed, one of them came every day. He was particularly comfortable with his son who took him on walks to the hospital and also to the community fair. The son was very good and was very careful with Mr. Hawkins' wheelchair.

Although very satisfied with his relationships with his friends, Mr. Hawkins had neither seen nor spoken with friends for more than a year. Similarly, Mr. Hawkins rarely saw relatives other than his children, although he had seen his sister for the first time in ten years the week before. He was somewhat satisfied with his relationship with her.

In terms of activities Mr. Hawkins thought it was quite important to have new and different activities from day to day. He was apparently active in the activity program at the nursing home. Similar activities every day, such as coffee every morning, were somewhat important. He said that he was somewhat happy with his activities and that they gave him something to think about.

Mr. Hawkins' total self-concept score was -.50 standard devia- 
tions below the mean. He also had negative scores in the areas of behavior, personal and social self-concept. Unlike most other respondents, Mr. Hawkins had a high self-criticism score, indicating an open-. ness to self-criticism. He was inconsistent in responses to negative and positive items, but did demonstrate consistency from one area of self perception to another.

\section{Mrs. Bishop - High Self-Concept}

Mrs. Bishop, 67, was manager of an old apartment building that appeared to be somewhat run-down. In the stage 1 interview she described her health as good although she had spent three nights in the hospital and three weeks in bed during the previous year. Her medical status score (2.75) was near the sample mean. Mrs. Bishop was able to go out alone and during the week before the interview she had been to church, a grocery store, bus stop and a restaurant. Her daily functioning (3.25) was high compared to others and her activity level

(2.57) was near the sample mean.

Mrs. Bishop was married (for the third time) and had no children. She reported having three confidants. In the week before the interview she had visited in person with neighbors, friends and others. She had seen a relative in the past month. She appeared to have more social contact (2.88) than other respondents in the sample.

Mrs. Bishop worked for rent and wages. She felt that her level of living was about the same as others her age and that she was worse financially than she had been ten years ago. Her income score (2.91) was near the sample mean.

Mrs. Bishop strongly agreed with the following statements: "I am 
just as happy as when I was younger", "I expect some interesting and pleasant things to happen to me in the future", "I would not change my past life even if I could", and "As I grow older, things seem better than I thought they would be."

The interviewer described Mrs. Bishop as difficult to interview. She was very willing, but was "up and down doing things" the entire time. Her cognitive status score was above the sample mean (3.33). At the time of the Stage 2 interview Mrs. Bishop said that her health remained good for her age, and that she was able to get out alone. She had lived in the neighborhood for 12 years and although she felt that it had changed for the worse, she felt that it was a good place for old people to live. Mrs. Bishop frequently visited with neighbors and was active in a local senior center.

Mrs. Bishop said that she called someone just to talk every day. She said that she could call on her friends night or day for help or when she needed someone to talk to. She could also confide in these friends and she saw friends every day. Relationships with her family were very important to Mrs. Bishop. She had spoken with relatives the day before and usually saw them once a month.

Mrs. Bishop felt that having both new and different activities and similar activities from day to day were very important. Activities included volunteering, drama club, television, and reading. Mrs. Bishop said that she was very happy with her activities.

Mrs. Bishop appeared very pleased to participate in the TSCS portion of the study and to be included in a research study. She enjoyed talking about herself and her experiences. She described many 
of her tenants and past and current problems. She said that she used to be a hateful person but was controlling her temper better, and was proud that she wasn't "cussing people out" so much anymore. Mrs. Bishop talked about having problems with her mother and relatives when she was young. She said that she "had a lot of dreams of dancing and piano" when she was young and "missed many chances." Still, she seemed pleased with her work and her activity, showing various items that tenants had made for her and discussing many of her activities at the senior center. She was planning to go on a four day trip with a group from the Center that week.

Mrs. Bishop had some concerns about keeping up with the apartment building. The heavy cleaning was getting to be too much for her and she could not afford to pay people to help. Still, Mrs. Bishop seemed to have a great deal of energy. As in the stage 1 interview, she was up and down throughout the interview--illustrating points and just moving around.

Results of the TSCS indicate that Mrs. Bishop had a positive self-concept (.42 standard deviations above the sample mean). She scored particularly high in the area of identity, physical, family and social self. Unlike most other respondents, Mrs. Bishop had a high self-criticism score, which suggests openness to self-criticism. Also, her high conflict and variability scores indicate some inconsistency of response to both positive and negative items and from one area of self perception to another.

\section{Mr. Porter - High Self-Concept}

Mr. Porter, 83, along with his wife of 67 years, lived with his 
daughter (in her home). In the first interview he described his health as good and said that he was able to get out alone. His medical status score was high (3.00) and his activity score (2.29) was similar to others in the conmunity sample. Mr. Porter's daily functioning score (2.75) was somewhat lower than the mean score for the community group.

Mr. Porter's social contact score was 3.00 , which was considerably higher than scores for either the nursing home or community sample mean scores. In addition to his daughter, the Porters have two other children. One lives ten minutes away and the other lives out of state. Mr. Porter reported having three confidants.

In the last week Mr. Porter had been to a grocery store, drug store and restaurant. He had also talked in person with neighbors, children and others, and had used the telephone. In the last six months he had been to a bank and had visited a friend. It had been more than a year since he had seen relatives.

The Porters had lived in their daughter's home for 14 years. They paid utilities and bought food. Their daughter hired a neighbor to help with housework. The Porters felt that their level of living was about the same as others their age and that it had not changed in the past ten years. If $M r$. Porter received extra money each month he said he would use it to cover funeral expenses. The income score (3.00) was higher than mean scores for either nursing home or community respondents.

Mr. Porter's cognitive status score (3.33) was also higher than mean scores from both samples. 
Mr. Porter agreed strongly with the following statements: "I am just as happy as when I was younger", "I expect some interesting and pleasant things to happen to me in the future", and "I would not change my past life even if I could." He agreed somewhat with "As I grow older things seem better than I thought they would be."

Mr. and Mrs. Porter and their daughter moved to an apartment and had been living there a year and a half at the time of the stage 2 interview. The apartment was in a new complex and was quite attractive. Mr. Porter expressed satisfaction with his living arrangement and neighborhood saying that "good clean, decent people live here. It's reasonable and quiet." He said that the neighbors visited with one another, although not with him. He said that he spoke to them about once a month.

At this time Mr. Porter said that his health was fair for his age; he had spent a total of three weeks in the hospital in the past year and said that he was confined to home.

In terms of social participation, Mr. Porter said that he called someone weekly just to talk. He indicated there were friends he could call on night or day if he needed help or needed to talk with someone. He said that he could talk to his clergy about things that bothered him.

Family relations were important to $\mathrm{Mr}$. Porter. During the TSCS portion of stage 2, he described his pleasure at being with his children and told of their mutual enjoyment when they were all together. He said his family was more than a duty and said they all liked each other. Mr. Porter also saw friends regularly, usually 
every week. He was very satisfied with relationships with both family and friends.

Mr. Porter felt that having new and different activities from day to day were not at all important but that having similar activities was very important. He was very happy with his activities which included painting, reading, television and gardening.

In the TSCS portion of the interview, Mr. Porter answered questions carefully. He was very pleasant and seemed very interested in the interview, although he did not comment extensively. He said that although he had had health problems in the past, he was presently feeling good. Mr. Porter talked about growing up in a family where reading fiction and dancing were frowned upon and reported that his wife had given up dancing in order to be accepted into his family. He laughed and he described learning and enjoying dancing in later years. He talked about his enjoyment with his family and his ability to care for himself.

Mr. Porter's self-concept scores were very high--.60 standard deviations above the mean. Unlike many other respondents, the selfcriticism score was also high, indicating an openness to self-criticism and, according to Fitts, lending credibility to the high scores. Mr. Porter had higher scores than the mean in all areas except social self-concept.

Net conflict scores were also lower, although high total conflict scores indicated some confusion and contradiction in self-perception as reflected by responses to negative and positive items. Variability scores showed a similar pattern to the mean scores. Low variability in 
internal areas of self perception was apparent while there seemed to be as well a lack of integration of external areas. As in most cases, high distribution scores showed a certainty of response.

10. Mrs. Hill - High Self Concept

In the first interview Mrs. Hill, 81, described her health as good for her age. She had not been to a doctor recently and had spent no days in bed in the past year and was able to go out alone. Her medical status score (3.67) was one of the highest reported. Her activity score (2.71) was also high and the daily functioning score (2.75) fell between the means of the nursing home and community sample respondents.

Mrs. Hill's social contact score was also very high (3.13). She said she had two children and then changed the number to six--four of whom lived out of state. (In the next interview she again said she had two children; no mention was made of the other four.l Her two children lived close by, one ten minutes away and the other within the metrc-olitan area. Mrs. Hill reported having two confidants.

In the preceding weeks Mrs. Hill had visited in person with friends, neighbors, children and others. She had also used the telephone, been to church, the bus stop and to the grocery store. It had been over a year since she had visited with relatives.

Mrs. Hill had been in her Housing Authority apartment for six years and in her neighborhood for over 30 years. Her housing score was higher than that of most respondents. She felt that her level of living was the same as for others her age and the. same as it had been for her one and ten years before. Mrs. Hill's income was similar to 
that of others her age and the same for her as it had been one and ten years before. Her income was similar to others in the community group. With an extra $\$ 50$ a month Mrs. Hill indicated she would buy a roast once in a while and a better variety of food. She also said that she would go out once in a while. With an extra $\$ 150$ a month Mrs. Hill would go to Utah to visit relatives. She agreed somewhat with the statements "I am just as happy as when I was younger" and "I would not change my past life even if I could." She strongly agreed with "As I grow older, things seem better than I thought they would be" but disagreed with the statement "I expect some interesting and pleasant things to happen to me in the future."

The interviewer described Mrs. Hill as enthusiastic and as enjoying the interview. She appeared to have no marked disabilities. Her cognitive status score (3.33) was well above the mean scores for the two groups.

In the stage 2 interview Mrs. Hill still felt that her health was good for her age. She had fallen and had been in the hospital for 18 nights. She said that she could get out only with help but that she hardly ever worried about her health.

Mrs. Hill expressed satisfaction with her neighborhood and with her housing arrangements. She lived close to her church, activity, family and friends. She usually called someone on the telephone every day. She felt her family could be called on at any time--to talk, if she needed help, etc. She visited with neighbors on a monthly basis and was satisfied with these relationships. She talked with both family and friends every day and visited in person with them each week, 
indicating her satisfaction with these relationships as well. Mrs. Hill saw relatives about once a year and also expressed satisfaction with these relationships.

In terms of activities, Mrs. Hill felt that both new and dif-: ferent and similar activities from day to day were very important. She said that she was very happy with her activities which included knitting, crocheting, and sewing.

During the TSCS portion of the Part 2 interview, Mrs. Hill talked about herself at length. She was attractive, nicely dressed, with makeup and jewelry. She was interested in the interview and very friendly. She said that she used to be really active, doing many things, but in the past year she had fallen and hurt her back and had not been able to get around as well as before. Mrs. Hill also was shaking from Parkinson's disease. The shaking interfered with her activity; she mentioned the difficulty in reading because she could not control her hands in order to keep the paper from shaking. Hwwever, she could control the shaking by doing handwork. Thus, she made bells from beads, normally completing one a day. She was working on one prior to the interview. Mirs. Hill appeared to have a very strong informal support system. Friends took her to church weekly and had done things like fix her bathtub so it was easier for her to bathe. A neighbor came in to read to her, her grandson bought her groceries every Saturday and her daughter paid her bills and took her shopping. That morning she had bought dresses which zipped up the front.

Mrs. Hill responded negatively to "I am a member of a happy family" because her other daughter had hardening of the arteries which 
had affected her mind. This daughter spent some time in a nursing home, which did not work out well, and then moved in with her son.. Mrs. Hill's other daughter often brought the second daughter to visit. It was a somewhat difficult situation for all involved.

Religion appeared to be very important to Mrs. Hilf. She was Mormon and most of her friends belonged to the church. She talked about going to Salt Lake City with friends in order to visit the Temple and her niece, nephew and sister. Her friends had a mobile home and they were making plans, to go that fall when it turned cooler.

Mrs. Hill talked about nursing homes. She said that she expected to go and that at one point she had begun looking at them; however, she did not like to think about it and could wait a while before she needed to do so. Friends and family had encouraged her to wait and she was glad of the advice. The major difficulty seemed to be meals, which she prepared herself. Meals on Wheels did not seem to be an alternative because they did not fit her schedule. In addition, she had not been able to find people to come in and help out.

Mrs. Hill's TSCS self-concept scores were generally high (.60 standard deviations above the mean) and, except for personal selfconcept, were above the mean of community respondents in all areas: She had a relatively high self-criticism score, indicating a healthy openness to self-criticism. Unlike most respondents, Mrs. Hill had a low variability and a low conflict score, indicating consistency in responses to items and an integration of the areas of self-perception. 
11. Mirs. Anderson - High Self-Concept

When Mrs. Anderson was first interviewed, she was 79 years old and was living alone in her own home of 21 years. The house was described by the interviewer as being in excellent conditions (housing score, 3.25).

At the time of the first interview (stage 1), Mrs. Anderson reported that her health was fair for her age and that she had not been hospitalized or in an institution in the past year. The interviewer indicated that she was shaking from Parkinson's Disease, but Mrs. Anderson said that she had no plans to see a physician. She said that she was able to go out alone, although she had some difficulty with mobility (e.g., crossing the street before the sign changed). The previous week she had been to the drug store and the bank. Mrs. Anderson's medical status score (2.50) was similar to the mean score for those later institutionalized. Her daily functioning (2.75) and activity scores (2.14) fell between the mean scores of the nursing home and community groups.

Mrs. Anderson was a widow with no children, but who appeared to have adequate social supports. She reported having six confidants, people with whom she would feel free to talk over very personal matters. During the week before the interview, she had talked in person with friends, relatives, and neighbors, and had spoken with persons on the telephone. A neighbor had done some repair work on her home ("but not much") and her sister had done housework (lirs. Anderson paid her for this). Mrs. Anderson's social support score was 2.38, below the means of both groups. 
During this interview Mrs. Anderson seemed impatient and irritated by some of the questions, particularly those concerning income. She would not tell the interviewer the amount of money she received from stocks and bonds, and from social security. She did indicate however that she never worried about money; she always had enough to eat and always had money left over at the end of the month. Her income score (3.27) showed her to have a higher financial status than others in the sample. The interviewer did report that Mrs. Anderson enjoyed the background questions where she described her life in Sweden and her immigration to the United States. She had come to Portland because a brother and sister were living here. Mrs. Anderson's cognitive status score (2.33) was low for both groups.

Mrs. Anderson was interviewed again two years later, after she had been living in a nursing home, an intermediate care facility, for nearly a year. The home appeared clean and attractive. There was a sun room/lounge where some of the residents were visiting with families. Mrs. Anderson had her bed by the window and had an attractive view of trees and shrubs surxounding the nursing home. There was a television and telephone beside her bed. She had a roommate, but they did not exchange any words during either visit by the interviewer. The roommate did not seem to be aware of the interviewer.

Mrs. Anderson had been in the nursing home for nearly a year. She seemed to have some difficulty remembering exactly how long she had been there. She stated that the nursing home "is as good as any" and "is supposed to be one of the best." Furthermore, she indicated, "the food and nursing are good and that is what is important, I suppose." 
She reported being very satisfied with the nursing home and could not think of any improvement that could be made, saying, "if I can't go home, I want to stay here."

Following the stage 1 interview, Mrs. Anderson's physical condition had deteriorated due to Parkinson's disease. She had sold her home and moved in with her sister and brother-in-law. At some point her doctor told her that she had to go to a nursing home and it was agreed that her sister could no longer care for her. Mrs. Anderson was unable to look for a nursing home, so her sister and niece did this for her. They felt that this particular facility was the best of those they looked at. Mrs. Anderson reported no money worries, saying that savings and money from stocks and bonds were paying her way.

Mrs. Anderson reported that her health was good for her age (compared to "fair" at the time of the first interview). She qualified this by stating, "that's what the nurses say." Compared to other residents in the facility, Mrs. Anderson was quite independent. She was ambulatory and took. care of much of her personal care.

In the nursing home, Mrs. Anderson seemed to keep to herself. She ate in the dining room and said she was "friends with everybody." At the same time, however, she also indicated, "I have never grown in with others" and said that she had not chosen to develop friendships with other residents. Her major activities revolved around her telephone and the television.

Mrs. Anderson maintained contact with friends and relatives, although at this time she reported only two confidants, her sister and her niece. She talked with her sister daily, had weekly visits from 
her, and sometimes urs. Anderson's niece took her out of the facility. Mrs. Anderson said she had seen her relatives about the same since she had been in the nursing home and said she was very satisfied with their relationship.

It was more difficult to maintain contact with friends. Mrs. Anderson saw them less often after living in the nursing home and rarely visited them herself. She did talk with friends on the phone at least weekly, however, and said she was very satisfied with these relationships.

Mrs. Anderson's attitudes toward this interview was much the same as toward the initial one conducted in her own home. During the first visit to the nursing home, the interview was fairly lengthy and Mrs. Anderson was very friendly but seemed impatient and irritated with some of the questions (e.g., "How satisfied are you with youx relationships with relatives, friends, etc.). She had doubts regarding the usefulness of the questions, answering all of them but without providing any additional information.

Mrs. Anderson's total self-concept score was .66 standard deviations above the mean. In addition, all the self-concept subscores were high except physical self which was similar to the mean score for the nursing home group. Mrs. Anderson's identity score was the same as that for the norm group, but higher than the mean score for the study sample. The high self-concept scores may be somewhat suspect, however. Mrs. Anderson's self-criticism score was quite low, suggesting denial and elevation of the self-concept scores. Conflict scores were also high, indicating inconsistency with responses to positive and negative 
items, and specifically suggesting a tendency to over-affirm positive attributes and a reluctance to deny negative attributes. The variability scores suggest a consistency from one area of self-concept to another although high column variability shows some inconsistency in external frame of reference areas. High distribution scores again show certainty in responses.

12. Mrs. Carter - High Self-Concept

Mrs. Carter was first interviewed in her one room apartment; her housing score was quite low (1.75). She reported that she was 90 years old and that her health was good for her age, she had not been ill during the past year. In spite of the fact that she was nearly blind, Mrs. Carter reported that she was able to go out alone and had no mobility problems. She had attended church and had been to the grocery store in the past week. A neighbor prepared her other meals for her. Medical scores (3.00), daily functioning (3.25), and activity scores were all higher than means for both groups. On the other hand, social contart. scores (2.00) were low. Mrs. Carter had been married and widowed twice. She had married her last husband 10 years before and he had died five or six years later. (although she was uncertain about the exact time). She reported having two confidants and indicated she had talked with neighbors, friends and others during the week. She also had talked with people on the phone.

Mrs. Carter has neither children nor relatives in Oregon. She left her home in wisconsin as a girl and all her relatives. (nieces) are in that state. She had one sibling who was no longer living. Mrs. Carter had not talked with her nieces in over a year. 
According to Mrs. Carter, she had no worries about money. A woman friend was handling her finances and she always had enough food and had money left over at the end of the month. Mrs. Carter's income score (3.36) was high, but there was some question about the accuracy of the response.

During this interview, Mrs. Carter was found to be a friendly, interested lady. The interviewer reported that Mrs. Carter had a faulty memory but had done her best to answer questions. This particular aspect is reflected by her low cognitive status score.

By Stage 2 Mrs. Carter was housed in the Residential section of a very large nursing facility whose services ranged from custodial to skilled nursing care, although she required little if any nursing care. Mrs. Carter was very friendly and appeared to enjoy having company. She talked at length about her working experiences and said that her health was good, although her vision was very poor. At both visits she was sitting in her chair, but there was a walker in the room. Mrs. Carter's memory seemed to have deteriorated considerably. on the second nursing home visit she forgot that she had met the interviewer the week before. Also during the second visit, a volunteer selling cookies and personal care articles came into the room who Mrs. Carter did not recognize although she seemed to be, a regular visitor and had indeed taken Mrs. Carter to her home for Christmas (several months before). In addition, Mrs. Carter did not know how long she had lived in the facility, did not know the names of friends, and so forth. In order to obtain more information, therefore, the social service worker at the home was questioned following the interview. According to her chart, Mrs. Carter had been there nearly two years (entering the home shortly 
after the stage 1 interview), although Mrs. Carter had reported being in the institution only four or five months. Mrs. Carter said she knew nothing about coming to the home until she was moved there and thought the woman in charge of her rent was the one who made the decision. She stated that, while she had no immediate plans to move from the home, she did want to move ("in a month or so") to the west side of Portland to be near her friends. She also felt that the home was too cold and too far from stores.

According to the social service worker, Mrs. Carter has tried to call friends but has never made contact. Mrs. Carter herself was uncertain about visits and contact from relatives and friends. She did say that she and her relatives used to be close but that "they are slipping away." She kept saying that she must get someone to write cards to her nieces, but that she didn't know their names. She also said that her relatives may visit in the summer, although the interview took place in october. Mrs. Carter had trouble remembering visits from friends. She thought someone had visited during the last week and thought this person came monthly, although she couldn't remember the visitor's name. She indicated that it was the woman who took care of her finances. The social service worker felt that the visitor Mrs. Carter referred to here is her conservator, who visits weekly, but did not know the conservator's name, nor did she know what the past relationship between the conservator and Mrs. Carter was. The social worker also indicated that Mrs. Carter is sometimes a problem for the staff because of her extremely poor memory and maintained that Mrs. Carter was about 10 years younger than she herself reported. 
Thus, Mrs. Carter was a woman virtually isolated from the community. In spite of visits from a volunteer and from her conservator she had no real involvement with the world outside the nursing home. She had lost contact with all her old friends and, in spite of the fact that she was a friendly womąn who enjoyed talking with others, Mrs. Carter was also alone within the facility.

When she was younger Mrs. Carter used to buy apartment houses; fix and sell them. She also used to dance. In the interview, however, she said that it is not too important to have new and different activities from day to day. At the stage 2 interview she reported being very happy with her activities saying, "All I do is make my bed and sit. You can't do much at 93." She did say that she would like a new dress and would like to get her hair done.

Mrs. Carter's TSCS scores followed the same general pattern as other nursing home respondents. Her total self-concept score was .69 standard deviations above the mean. Her self-criticism score was lower than the norm, indicating defensiveness, and suggesting that positive scores were artificially elevated. The high net conflict scores indicated that Mrs. Carter was over-affirming positive attributes. The total conflict scores were indicative of lack of confusion or inconsistency in the self-concept.

In examining row and column scores, it appeared that behavior, self-satisfaction, physical self-concepts and personal self-concepts were somewhat higher than the norm group.

Variability scores were low, indicating consistency from one area of self-perception to another. Distribution scores were quite similar 
to the norm group, suggesting certainty in her responses.

\section{Mrs. Smith - High Self-Concept}

In Stage 1, Mrs. Smith, aged 83, described her health as good. She had not been hospitalized or in bed from illness in the last year. Both her medical status (3.67) and her daily functioning (3.25) scores were above the sample mean:- She was able to go out alone. In the past week, Mrs. Smith had been to the grocery store, the bank, and to the bus stop. Her activity level (2.43) was similar to that of others in the sample. Mrs. Smith's cognitive status was high (.96). She had one son living in the metropolitan area and had seen him in the past week. She had also visited with neighbors and had called someone on her telephone. She said that she had no confidants because "I don't like to bother other people with that." Her social contact score (2.43) was near the sample mean.

Mrs. Smith had been in her apartment, part of a public housing high-rise, for three: and a half years. It was attractively furnished and r 11 kept, as reflected by the housing score (3.50). Mrs. Smith's income was low (2.55) and she felt, worse financially than others her age, although she was better off than she had been a year ago. With extra money each month Mrs. Smith said that she would like to have a house, to travel, and would buy new furniture and clothes. She told the interviewer that she had given her son $\$ 300$ (almost all. of her savings) when he was out of work. She felt uncomfortable telling about it and was anxious that no one learn about it.

Mrs. Smith strongly agreed with the following: "I am just as happy as when I was younger" and "I would not change my past life even 
if I could." She disagreed sonewhat with "As I grow older things seem better than I thought they would be" and disagreed strongly with "I expect some interesting and pleasant things to happen to me in the future."

In the Stage 2 interview Mrs, Smith described her health as good; she had no health problems, never worried about health, and was able to get out alone. She was very satisfied with her neighborhood and with her housing arrangements. She said that people in the building did not visit one another, but that she saw and spoke with then daily.

Mrs. Smith said that she was very satisfied with her relationships with family, friends, and relatives. She had visited with her son the day before the interview and saw him weekly. She spoke with friends weekly and visited with them in person every month. Relatives were seen less than once a year.

In terms of activities, Mrs. Smith. felt that new and different activities from day to day were not at alI important but that having similar activities was very important. Mrs. Smith said that she was very happy with her activities, although money would improve them. Her activities included watching sports, gardening, walking, traveling, and cooking.

Mrs. Smith was very willing to be interviewed again for the TSCS portion of the stage 2 interview. She was friendly, cheerful and well dressed. Her apartment was very attractive. She said she was pleased to do the interview because she had grandchildren working on masters degrees and understood. what was involved. She laughed throughout the interview saying that she often sounded like she was bragging. 
Mrs. Smith was widowed when her. son was very young and, thus, she went to work for the first time in her life. She was proud that she had managed so well. Her son was successful and Mrs. Smith was proud of him and his family. She was especially proud of living independently and that she had not accepted money from her son.

Mrs. Smith talked some about the people in her building. She kept herself distant from them because they dwelt on aches and pains-which bored her--and gossip which she did not approve of. She had a high total self-concept score (.75 standard deviations above the mean). Sub-scores showed a positive self-concept, particularly in the areas of identity behavior, physical, personal, and family self. Her selfcriticism score was above the mean, indicating more openness to selfcriticism than others in the sample. She was inconsistent in responses to positive and negative items, but the variability scores indicated consistency from one area of self-perception to another.

14. Mr. Landon - High Self-Concept

At Stage 1, Mr. Iandon, a married man with no children, described himself as having fair health for his 68 years. He had not spent any days in bed because of illness in the past year and was able to go out alone. His medical status scores were lower than other community respondents (2.67). His functioning and activity scores, however, were higher than the mean responses of the two groups. Mr. Landon, however, had a history of poor health. He had had polio when young and now had arthritis. He and his wife moved to Arizona 25 or 30 years ago because of the arthritis. The climate was not beneficial, however, and according to his wife "it nearly killed him." They moved to oregon 
about 20 years ago and have lived in their apartment for five years. Mr. Landon reported having five confidants. In the past week he had spoken in person with neighbors, relatives, friends, and others. He had also called people on the telephone and had been to a drugstore, grocery store, bank, restaurant and church. His social contact score (2.50) was slightly lower than the institutionalized group. During. the past year Mr. Iandon had arranged for home-delivered meals and for fixing up the apartment. The Landons had not received any other formal service.

Mr. Iandon's cognitive score (2.33) was lower than the mean scores of both groups.

Mx. Iandon felt that their level of living was about the same as it had been both one year and 10 years ago. The income score $(2.27)$ was low. If he were to receive an extra $\$ 50$ a month $\mathrm{Mr}$. Landon said they would probably eat out more often and with an extra \$150 they would take more trips and perhaps go fishing.

Mr. Landon disagreed somewhat with the following statements: "I am just as happy as when I was younger", "I expect some interesting and pleasant things to happen to me in the future", and "I would not change my past life even if I could." He agreed somewhat with "As I grow older, things seem better than I thought they would be."

In the Stage 2 interview (part 1), Mr. Iandon described his neighborhood as a good place to live. He said he was somewhat satisfied with his neighborhood, but that some of the tenants in the apartment complex bothered them, staying up late with all night parties. He felt that more married couples were needed in the building. Neighbors 
did not visit one another often. Although he and his wife spoke with neighbors daily they visited or were visited by neighbors about once a month.

Relationships with family were described as very important and Mr. Landon reported being very satisfied with them. He said that he and his wife spoke with and visited relatives about once a week. He had spoken in person with relatives in the last rnonth. The Irandons also saw friends frequently. They had visited friends the day before the interview and generally visited with them each week. Mr. landon said that he was very satisfied with these relationships.

In terms of activity, Mr. Landon indicated that neither new and different activities every day nor similar activities were very important. Mr. Iandon enjoyed several types of activity, particularly cards. He said that he was very happy with his activities.

When contacted for part 2 of the stage 2 interview (the TSCS), Mr. Iandon requested that the interview take place in the morning so as not to interfere with afternoon television programs. He and his wife were ready and waiting at the appointed time. Mr. Iandon was at the table playing cards. His wife had pulled the stove away from the wall looking for ants; she had seen the two the day before and wanted to be sure that there were no more. She quit her search when the interview began and sat at the table during the procedure. In conversation she had a tendency to dominate, although she said little during the actual interview. Mr. Iandon laughed a lot and seemed somewhat nervous. Both were friendly, enjoyable people and both were in poor health. They gave the impression that Mr. Landon could not walk well: that he needed help 
getting out of chairs, with showers and with other personal care. At the same time, however, they went out regularly and $\mathrm{Mr}$. Landon drove then: to the store, church and out to eat. Mrs. Landon had Parkinson's disease, although symptoms were pretty well controlled with medication. She appeared to have a lot of nervous energy and spent a great deal of time cleaning. They both talked fluently about their past work life, relatives, etc.

Mr. Iandon's TSCS scores showed a high total self-concept, .78 standard deviations above the mean. He was above the mean in all areas of self-perception with particularly high scores in self-satisfaction, behavior, moral-ethical and personal self-concepts. Mr. Landon had a very low self-criticism score, suggesting that the high self-concept scores were inflated due to denial. The low conflict scores showed consistency in answering positive and negative items and the low variability scores showed consistency from one area of self perception to another.

\section{Mrs. Wilson - High Self-Concept}

At the time of the Stage I interview, Mrs. Wilson, aged 67 and a widow, described her health as poor. She said that she had spent 80 to 100 days in bed during the past year and that she could only leave the house with help. Her medical status (2.33) and activity scores (2.00) were low, but her daily functioning score (3.25) was quite high-above the mean scores for both nursing home and community samples. Mrs. Wilson had no children, but reported having three confidants. In the past week she had visited in person with friends, neighbors, and others and had used the telephone. Her social contact score was 2.25, 
which was lower than the mean scores of both groups. In the previous month Mrs. Wilson had been to the grocery store and to the bank. It had been up to six months since she had been to a drugstore or church and more than a year since she had been to a restaurant.

When asked what she would do with extra money each month Mrs. Wilson indicated that she would have an operation to remove a growth on her back, that she would spend the money "carefully, pay up bills I owe", get to the doctor a little more often and not let medicine run out, and that she would pay insurance and Elks dues. In terms of her level of living, Mrs. Wilson felt that she was worse financially than other people her age. She also felt that she was in worse condition than she had been 10 years before, but better than she had been a year before. Her income score (2.55) was lower than the mean scores for both community and nursing home samples.

Mrs. Wilson agreed strongly that "I am just as happy as when I was younger" and "I would not change my past life even if I could." She agreed somewhat that "I expect some interesting and pleasant things to happen to me in the future" and "As I grow older, things seem better than I thought they would be."

Mrs. Wilson's cognitive status score (2.67) fell between the mean scores of the nursing home and community groups.

The first part of the stage 2 interview took place two years later. Mrs. Wilson expressed satisfaction with her home and her landlady. She indicated that the neighborhood had deteriorated in recent years, but said that she felt safe and could "ask my neighbors for. anything." She was living with her niece and nephew. 
As in the first interview, Mrs. Wilson seemed concerned with her health. At this time she rated her health as "fair" (compared to "poor" at stage 1). She had spent a total of five weeks in bed in the preceding year and felt herself confined to home.

In terms of social participation, Mrs. Wilson called someone on the telephone "just to talk" about once a week. She listed police, neighbors and friends as people she could call on day or night. She identified her clergyman as someone she could talk to about anything bothering her or being important to her. It is interesting to note that Mrs. Wilson did not refer to her niece or nephew. Similarly, when asked how often she saw her relatives, Mrs. Wilson did not seem to "count" her niece. She said that she saw relatives only once a month, and that she was "very satisfied with her relationship with them." Mrs. Wilson spoke with friends daily and visited in person with them each week. She also said that she was very satisfied with her relationship with friends.

Mrs. Wilson felt that having new and different activities every day was not too important but that having similar activities was somewhat important. Her activities consisted of church, work for missionaries, Elk Lodge, cleaning house, and watching television.

The second part of stage 2 consisted of the TSCS. Mrs. Wilson had an unlisted number and so was visited at her home in order to ask for her participation, to explain the interview, and to set up an appointment. She was not happy about the request, indicating that the last one had been too long and further that she wasn't feeling well. When informed that it could be done in 20 minutes she responded, "That's 
what the last one said." An interview form was left for her to look over and she was visited again two days later. She reluctantly agreed to the interview but made it clear that 20 minutes was the limit saying, "The last one was here two and a half hours and made me so nervous asking the same questions over and over. I wasn't feeling we1l." Later in the interview it became apparent that part of her resentment was due to the fact that welfare payments had been reduced shortly after the last interview and she felt that it was because of the information she had provided.

Mrs. Wilson's house was attractive (with a beautiful yard), but was kept very dark.

In response to the first item of the TSCS, "I have a healthy body", Mrs. Wilson showed her various scars from recent surgery and from an automobile accident which occurred in 1963. The interview took one. and a half hours but she seemed to enjoy it thoroughly: (After 20 minutes she had been asked if the interview could continue. With a laugh, she said that she had been using the time herself and agreed to continue.) Much of Mrs. Wilson's discussion concerned her health. She was upset with doctors not giving medication. She described one occasion when she was "paralyzed for a while." She went to the hospital, but they sent her home. She felt that they should have done more for her.

Mrs. Wilson appeared to have many important supports. Neighbors had taken her to the hospital and during the interview a neighbor boy brought her something from his mother. Mrs. Wilson also had a phone call during that period. In terms of family, the kind and amount of 
support which Mrs. Wilson received from her niece was unclear. one of her few comments about her niece was in response to the statement "I'm too sensitive to things my family say". Mrs. Wilson said, "I have a niece with a big mouth, but I don't worry about it." She seened to do most things by herself.

Mrs. Wilson was one of ten blacks in the entire sample $(n=397)$. She spent much of her working life cleaning homes and watching children. She had maintained contact with many of the families she worked for; there were several pictures of these people on her mantle and she showed a photo album with several more. She also displayed a robe one family had brought her from Moracco.

Mrs. Wilson's total self-concept score was high (.78 standard deviations above the mean), although low self-criticism scores indicate these may be artificially elevated. In the sub-categories of selfconcept, Mrs. Wilson was above the mean scores of the community group in all areas except physical self (which was near the mean score) and moral-ethical self, where the score was much lower. Mrs. Wilson's scores were especially high in the areas of behavior, self-satisfaction, and personal and social self.

Conflict scores were considerably lower than the mean scores, indicating more consistency in negative and positive responses than was apparent in other respondents. Variability scores were.similar to mean scores indicating some consistency, although there were contradictions in the external frame of reference areas of self-perception. High distribution scores again suggest certainty in response. 
16. Mrs. Nelson - High Self-Concept

At Stage 1, Mrs. Nelson, a widow with no children, was described by the interviewer as a delightful woman with a sense of humor. At the conclusion of the interview, when asked "Is there anything else that I haven't asked about that you think we should be asking?" she replied, "You didn't ask if I play football or what my bridge score is." Her cognitive score was high (3.00).

At the first interview she described her health as good for her age (79 years) and that in spite of her bad.knee she was able to get out alone. Her medical status (3.00), activity (2.71), and functioning scores (3.25) were all higher than means scores of others in the community sample.

Mrs. Nelson's social contact score (2.13) was lower than both group means. She reported having no confidants. In the past week she had been to a grocery store, restaurant; and church. She had visited in person with a neighbor, relative, friend, and other individual (neither relative, neighbor, friend). She had also called someone on the phone.

Mrs. Nelson's income score was slightly higher than the nursing home sample means. She felt that her level of living was about the same as others her age, and that although she was about the same financially as she had been a year before, she was worse off now than she had been 10 years before. With an extra $\$ 50$ a month Mrs. Nelson said that she would get more clothes and perhaps help her niece. With an extra \$150 a month Mrs. Nelson said, "I'd help my niece--that's for sure." She also said that she would save the rest of it for a rest 
home, commenting that it had cost her sister $\$ 1,000$ a month to stay in one.

Mrs. Nelson said that she worried about the future, although she agreed somewhat that, "As. I grow older things seem better than I thought they would be" and "I am just as happy, as when I was younger." She strongly agreed that "I would not change my past life even if I could". She disagreed somewhat with "I expect some interesting and pleasant things to happen to me in the future."

In Stage 2, Mrs. Nelson said that she had no health problems and that her health was good for her age. She continued to be able to get out alone. Mrs. Nelson felt that her neighborhood was a good place to live; she had good neighbors and was very satisfied with the neighbor-: hood and with her relationships with neighbors.

In terms of social participation, Mrs. Nelson said that she called someone daily just to talk. She said that she had a friend she could call day or night if she needed help or if something bothered her. Mrs. Nelson said that relationships with family were very important. She said that she talked with relatives weekly and was satisfied with her relationship with them: However, earlier she said that she never talked with relatives, and in a later interview indicated that there was friction with her husband's family. Mrs. Nelson saw friends daily and indicated being very satisfied with these relationships.

Mrs. Nelson was very happy with her activities of cards, reading and yardwork. She said it was somewhat important to have new and different activities from day to day, but very important to have similar activities from day to day. 
The second part of the Stage 2 interview provided more insight into Mrs. Nelson's activities and her informal support system. At the time of the interview Mrs. Nelson's neighbor and close friend, Mr. Brown, was there reading the paper. While Mrs. Nelson was interviewed in the kitchen, Mr. Brown took a nap in the living room. They had arranged that Mr. Brown would take Mrs. Nelson shopping and she would cook meals for both of then. They spent much time together. Mr. Brown's daughter, who lived in the metropolitan area, also provided help for both of them. Mrs. Nelson's husband's relatives live close by, but never visited her. She seemed to think they did not approve of lir. Brown. Mr. Brown's wife was living but had been in a nursing home for many years. At one point Mrs. Nelson said that she lives and depends on Mr. Brown a lot; she feels that if it weren't for him she would be in a nursing home.

Mrs. Nelson appears to have many worries and real fears for her future. She appeared healthy, her home was kept up well, there was a garden to tend, yet she had many fears. Her husband was ill for five years prior to his death and he spent part of that time in a nursing home. Mrs. Nelson maintained, "I didn't put him there, the doctor did." Mrs. Nelson's sister also spent time in a nursing home. Both Mrs. Nelson's sister and particularly her husband had had bad experiences with the nursing homes and these memories contributed greatly to Mrs. Nelson's fears. Mr. Brown was to have an operation the following week and, although his daughter was going to look in on Mrs. Nelson, this additional concern seemed to cause her more anxiety, for her own future. She cried when speaking of it. 
Mrs. Nelson indicated she was fond of sports and had played tennis and basketball in high school. She was very upset about Bill Walton's decision to leave the Trailblazers; she cried while talking about it and had several newspaper articles on the subject.

Mrs. Nelson's total self-concept score was high (.93 standard deviations above the mean), although this was coupled with a low selfcriticism score. In the sub-categories of self-perception, Mrs. Nelson was above the mean in all areas. Her scores were particularly high in areas of behavior and self-satisfaction, physical self and social self.

Mrs. Nelson's conflict scores were low, indicating a tendency to over-deny negative attributes. On the whole, however, responses to negative and positive items were fairly consistent. Variability scores were low, indicating consistency across areas of selfperception. Finally, distribution scores indicated certainty in response.

17. Mr. Harris - High Self-Concept

When Mr. Harris, 81, was first interviewed, he was described by the interviewer as apathetic and lethargic and "worried sick about what's going to happen to him." His voice was barely audible and he cried several times during the interview in response to questions. about family and income. His cognitive score $(2.00)$ was quite low. Mr. Harris indicated that his health was good for his age, but that he had spent about three weeks in the hospital and said that he was concerned about his health. His medical status score (2.40) was low, but his activity score (2.29) was similar to the community sample 
while his daily functioning score (2.75) fell between the nursing home and community sample means.

After leaving the hospital Mr. Harris had sold his home and moved in with his daughter. According to an old friend, his daughter felt he should go to a nursing home but $M r$. Harris resisted and moved into a trailer with this friend. At the time of the interview he had been there two and a half months. He paid no rent, but did share costs of meals. He was able to get out and did most of the grocery shopping. In addition to grocery shopping, Mr. Harris had spoken with a friend, neighbor and other people. In the last month he had talked with his daughter and had called someone else on the phone. The friend said that Mr. Harris would either remain with her or go back to live with his daughter but insisted that she would not allow Mr. Harris to be put in a nursing home. She indicated that Mr. Harris could stay at her house indefinitely. Mr. Harris's social contact score was 2.50, similar to other nursing home respondents.

In response to attitudes about aging, Mr. Harris agreed somewhat that he was "just as happy as when I was younger". He began to cry at this point, however, so the interviewer did not ask the remaining three questions.

Approximately one year later Mr. Harris entered a nursing home. At the time of the stage 2 interview he had been there for a year. He had gone to the nursing home because his health had deteriorated, he "had a low blood count" and, as a result, had been unable to walk. He had come to the nursing home to get "built up" and was now able to walk again but "not good." Mr. Harris felt that his health was fair. 
His daughter had helped him find the nursing home and he thought it was a good place to live. He had no plans to move because he "knew everyone" in the facility. (It was the same facility where Mrs. Sanders lived: approximately 80 residents, fairly new and attractive.) Mr. Harris maintained contact with friends and family. He called friends about twice a week and often spent weekends with them away from the facility: He also maintained contact with his daughter and felt he could call her at any time. She came to see him two or three times each week and he went home with her two or three times a nonth. other residents at the facility were important to Mr. Harris. He helped people with their wheelchairs and in other ways and was very active in many things--particularly exercises. He also enjoyed playing cards. Mr. Harris still had a tendency to cry when talking about family members who had died, but the frightened, lonely man described in the first interview had become a vital, active person with many friends and interests.

In many ways Mr. Harris seemed to have the best of both worlds. He had very real support from friends and family outside the nursing home and he had friends and a sense of purpose within the facility. Mr. Harris's TSCS scores were extremely high. His total selfconcept score was 1.64 standard deviations above the mean score for nursing home respondents. Mr. Harris's most extreme scores were in the areas of self-satisfaction and personal self-concept. They were also very high in the areas of behavior, moral-ethical, and social self-concept.

Again, high scores are somewhat suspect because of the extremely 
low self-criticism score. The net conflict score was similar to the mean score, indicating a tendency to over-affirm positive attributes. The total conflict score, however, was low, but not quite to the extreme. According to Fitts, this score shows a lack of confusion or contradiction in response to negative and positive items.

Mr. Harris's variability scores were also quite low showing consistency from one area of self-perception to another. Distribution scores showed a high degree of certainty to responses to scale items.

\section{Mrs. Foster - Mean Self-Concept Score}

At Stage 1, Mrs. Foster, 78, described her health as poor, although her medical status score was high (3.00) compared to others. She was also able to go out alone. In the previous week she had been to the grocery and drug stores, but generally had low activity $(2.00)$ and daily functioning scores (2.25).

Mrs. Foster had one child who lived within ten minutes of her. She reported having three or four confidants. It had been a month since she had visited with children or had spoken with someone on the telephone. It had been six months since she had spoken with a friend. Mrs. Foster's social contact score (2.57) was similar to others in the institutionalized sample.

Mrs. Foster had lived in her apartment for 12 years. The interviewer described it as being in fair condition. Her housing score (1.50) was very low.

Mrs. Foster felt that her level of living was about the same as others her age and about the same it had been both one and ten years before. Her income score, however, indicated that her financial 
status was much better than others who participated in the study. Mxs. Foster received Meals on wheels for which the apartment manager had arranged. Another tenant had suggested someone to help with her housework.

Mrs. Foster felt that it was best for people to live in neighborhoods where everyone was the same age. She disagreed strongly with "I am just as happy as when I was younger", although she agreed somewhat that "As I grow older things seem better than I thought they would be." She disagreed somewhat with "I expect some interesting and pleasant things to happen to me in the future" and "I would not change my past life even if I could."

The interviewer reported that Mrs. Foster had difficulty remembering all the dates and figures. She did not recall how or when she moved to Oxegon. She was rated as having a low cognitive status score $(2.33)$

At Stage 2 Mrs. Foster was in a 120-bed, skilled intermediate care facility. The home was fairly attractive with a large lounge area. In calling the nursing home to explain the purpose of the study, the administrator referred the interviewer to the activity director, who expressed concern with Mrs. Foster's lack of activity.

on the first visit (to set up an appointment), Mrs. Foster was in bed. She had the middle bed in a three-bed ward. The room was dark and a roommate was also in bed. The activity director reported that Mrs. Foster spent most of her time in bed, rarely leaving the room. The first visit was short. Mrs. Foster seemed pleasant and joked about an appointment, saying that she would be there any time. 
on the second visit Mrs. Foster was sitting up in bed. She sniled some but kept her head down, looking at the floor. She was constantly running her hands over her clothes and the table. Her answers were sometimes very slow and she did not volunteer any information. Probing was difficult and there was some question about the accuracy of information given, particularly statements about friends and family.

Mrs. Foster said that she had lived in the nursing home for seven months, "but my daughter-in-law says it's been a year." She thought the nursing home was a fair place to live, adding that "people can't do any better." She was somewhat satisfied with the nursing home, but that was largely because "you have to be." She said she was institutionalized because she fell and injured herself by breaking her hip and ankle. She felt that her health was poor for her age, repeating this several times throughout the interview. She said she got around only "as much as I have to." This consisted mostly of walking to the bathroom with her walker. She did not choose the nursing home herself, saying that "they" did. "They" referred to "the authorities", but she was not more specific. Mrs. Foster also stated that she had been notified that her house would be torn down and, thus, she would be forced to stay in the nursing home. She later said that she had plans to move but had not yet chosen a place. Within the nursing home Mrs. Foster felt that she could talk to the nurses about anything that really bothered her. Regarding other residents, she said she knew some of them but that "I haven't had visitors lately. My energy has been low. I couldn't digest my food, 
so I didn't see peop.e" She said that she was very satisfied with her relationships with other residents.

Mrs. Foster had one son and two grandchildren whom she felt she could call day or night if she needed them. She said that her relationship with them was very important to her and very satisfactory. She saw them prior to institutionalization. Mrs. Foster could not remember the last time she had seen a friend, although she thought that she might see them once a week. Mrs. Foster had not seen relatives for some tine saying, "In my old home maybe, but not in this place."

In terms of activities, Mrs. Foster felt that it was more important to have similar activities from day to day than it was to have new and different activities. She said that she did not participate in activities although she read sometimes. She said that she was very happy with her activities.

Mrs. Foster's total self-concept score was near the mean $(.03$ standard deviations). She was below the mean in the areas of selfsatisfaction and physical self and high in the areas of family and social self. She had a low self-criticism score, indicating denial or lack of self-awareness. Finally, her responses were somewhat inconsistent.

19. Mrs. Williams - Mean Self-Concept Score

Mrs. Williams, who at stage 1 was 98 years of age, was the oldest person in the sample. She was relying on several services but in many ways was quite independent. She described her health as good for her age. The interviewer said that Mrs. Williams did not believe 
herself to be bedridden but did say that she spent a lot of time in bed resting. She was a Christian Scientist and did not go to doctors. Her medical status $(2.50)$ was slightly below the mean and her daily functioning score was near the mean (2.50). Mrs. Williarn' activity score (1.00), however, was nearly two standard deviations below the mean of the institutionalized sample.

The interviewer described Mrs. Williams as being "housebound but in control." Mrs. Williams had a friend who worked in a grocery store and brought her groceries. Meals on wheels were delivered three times a week and, on other days, a woman cane to prepare the meals. This woman also cleaned, changed the bed and sent out laundry. She left food for evening meals and Mrs. Williams was able to manage them herself. (The interviewer said that throughout the interview the respondent was eager to get some-strawberries. The interviewer stated further that the "Respondent refused any and all offers of help. Before I left she was using her walker to get to the strawberries. God help any rest home she ends in.") Mrs. Williams' cognitive score (2.00) was low, more than one standard deviation below the mean. The friend who delivered groceries and the woman who cleaned for her appeared to be Mrs. Williams' major sources of social support. Mrs. Williams was divorced when she was young, never had children, and never remarried. She made her living designing clothes. Mrs. Williams' social contact score was low (1.75). She had seen her friend and used her telephone in the past week but had not talked with a neighbor for a month. It had been over a year since she had seen any relatives. 
Mrs. Williams' housing condition (3.25) was better than many of those who were interviewed, possibly because of outside assistance. Mrs. Williams was unclear about other help she was receiving, particularly financial aid, stating that she did not think she received any social security. Her income (2.55) was low compared to others in the sample.

Mrs. Williams described "an awful experience" during which a lawyer had wanted to becone her guardian. She said she had to go to court with an appointed attorney she did not like. It apparently was decided in her favor since the lawyer was not made guardian.

In terms of attitudes toward aging, Mrs. Williams disagreed somewhat with all the following statements: "I am just as happy as when I was younger", "I expect some interesting and pleasant things to happen to me in the future", "I would not change my past life even if I could", and "As I grow older things seem better than I thought they would be".

At the conclusion of the stage 1 interview Mrs. Williams was asked if she had anything to add. Her reply was, "Well, goodness, it's been hellish. I hope the damned fools got what they wanted."

When interviewed for stage 2 Mrs. Williams was 100 years old and had been in the nursing home "a long time." It was a fairly large, new, attractive facility. She said that the nursing home was a very poor place to live and that she was very dissatisfied with it. The major problem appeared to be poor meals. Mrs. Williams also talked about the staff but did say that mostly. "they mean to do what's right." Similarly, Mrs. Willians said that "some of the girls call me Aunt 
Mary. I kind of like it." She had noved to the nursing home because "they were gonna push me out because someone was waiting for the room. They pushed me out; I couldn't help it." She had no plans to move. Mrs. Willians still felt that she was not a sick person, "just the usual running down", and that her health was good for her age. She stated that "my teeth are gone, but I keep up pretty good." In that first visit she was curled up in the middle of a very rumpled bed but during the actual interview the bed was much neater.

Mrs. Williams reported that a Christian Science practitioner comes to see her every week and that, in addition to him, there were church nembers she could call if she needed help. similarly, she felt that she could talk to the Christian science practitioner about anything important to her. Mrs. Williams said that she saw her friends (referring to the practitioner) more often since she had been in the nursing home. She did not mention the woman who had cleaned for her or brought her groceries. She said that the people in the nursing home did not often visit with one another but that she was very satisfied with her relationships with them. She said, "I'm not crazy about visiting" and that "most people in the nursing home are kind of goofy."

In the past, Mrs. Williams had been active in the Eastern star and in the Masons. She also had enjoyed playing pinochle. In response to questions concerning activities Mrs. Williams indicated that it was not too important to have new and different activities from day to day and only somewhat important to have similar activities. She herself was not too happy with her activities which consisted of 
"laying here, eating, and using the pan."

Mrs. Williams had nephews in Colorado but it appeared that she had not seen them for several years and that they rarely corresponded. She became somewhat irritated and upset at the questions concerning family, thus, in the TSCS portion four questions were not asked. (The modal response was used to fill in missing data.)

20. Mrs. Hart - Mean Self-Concept Score

When Mrs. Hart, 78, was first interviewed, she was married and in fair health. She could get out only with help. The interviewer further indicated that she was nearly blind and hard of hearing. In the last week she had been to the grocery store and had talked in person with a neighbor, relative, friend, and had called someone on the telephone. She felt that she and her husband were better off than other people their age and that their level of living was about the same as it had been ten years before.

Mrs. Hart disagreed somewhat with the following statements: "I am just as happy as when I was younger", "I expect some interesting and pleasant things to happen to me in the future", and "As I grow older things seem better than I thought they would be". She agreed somewhat that "I would not change my past life even if I could." When Mrs. Hart was interviewed at stage 2 she had lived in the nursing home about a year. Her husband had died and she had sold their home. Because she didn't want to live with relatives, she had gone to live in the nursing home. She said that she had had friends who had lived there and who thought it a good place to live. The building was not large; approximately 70 residents lived there. 
Mrs. Hart shared a room with two other women; she had the middle bed. Mrs. Hart was ambulatory but the staff seened to prefer her to stay in one place. On two occasions she was seated in a day room with a table in front of her chair. The room was noisy with television and general talk. The residents did not seem to talk with each other very much. Mrs. Hart said that she knew everyone and made disparaging remarks about some of the other residents in the room.

Mrs. Hart was vague about many things, such as identifying a confidant and reporting on her relationship with her brother. This vagueness was due in part to her interest in activity around us and in part to the fact that she was hard of hearing and did not always understand the questions.

Mrs. Hart was visited three times. She was friendly throughout the interview, but did not remember the interview from one visit to the next. She appeared to have had a difficult life. She married and had a son when she was 16. After three years her husband left her. Mrs. Hart declared, "I never loved anyone again." she remarried and lived with her second husband nearly 60 years. He died the year before the interview. She cried a little, saying that she missed him. At some time Mrs. Hart had given birth to a daughter who eventually disappeared; Mrs. Hart never found out what happened to her and indeed had never known whether or not she was still living. Mrs. Hart adopted her granddaughter. She lives in Oregon although Mrs. Hart does not see her often. Mrs. Hart often referred to her as "my daughter" and was upset with her marriage and the fact that she quit going to church. Mrs. Hart also had a son, but she hadn't seen him 
for a long time. She was not sure where he lived, but mentioned a "big house in Hollywood." She thinks he works for the government, but isn't sure.

The final interview ended when a group of singers went through the nursing home. Mrs. Hart joined in and quickly seemed to forget the interview.

IIrs. Hart's TSCS scores indicate that her self-concept was near the mean in all areas of self-perception. Similarly, her selfcriticism score was low and her responses were inconsistent both in response to positive and negative items and from one area of selfperception to another.

\section{Mrs. Haskins - Mean Self-Concept Score}

Mrs. Haskins, 81, was interviewed in her home, with her son present for the entire interview. The interviewer said that the son read the entire interview before allowing it to proceed. He was dubious of its worth, but made no comments at all during the interview.

Mrs. Haskins described herself as in fair health. In the past year she had spent 14 nights in the hospital and could go out only with help. She had three children. Her son lived ten minutes away and her other two children lived out of state. She said that there were two people with whom she felt free to talk over very personal matters.

In the week prior to the interview, Mrs. Haskins had spoken in person with a friend, children, grandchildren, and others. She had also used the telephone. In the last month she had been to a drugstore and in the last six months she had visited with a neighbor and 
and had been to church and to a restaurant.

Mrs. Haskins had lived in her hone for 40 years. She felt that her level of living was about the same as that of others her age and that it was about the same as it had been both one year and ten years before. With an extra $\$ 50$ a month Mrs. Haskins thought that she would buy clothes and "eats" such as icecream. With an extra $\$ 150$ per month she would put some of the money away, to be used for her burial. She also thought about buying a color television.

Mrs. Haskin's daughter-in-law prepared all her meals and did her housework. Her son helped to fix up her home. She said that medicare had helped to arrange for a walker and that she had attended the senior center.

Mrs. Haskins disagreed somewhat with the statement "I am just as happy as when I was younger." She strongly agreed with the statements "I expect some interesting and pleasant things to happen to me in the future" and "I would not change ny past life even if I could". She agreed somewhat with "As I grow older things seem better than I thought they would be."

The interviewer described Mrs. Haskins as being very thin and as having some shortness of breath. The length of the interview tired her and the interviewer felt she could not probe as she might have done earlier.

Mrs. Haskins was interviewed two years later. Her son and daughter-in-law had moved in with her and once again her son was present for the entire interview. Mrs. Haskins expressed satisfaction with her living arrangement and with her neighborhood, although she 
thought the area should be patrolled more often. She said that the neighbors "are pleasing" but that they do not often visit one another (perhaps only once a month).

Mrs. Haskins' health remained fair and she was able to get out only with help. She said that she called people just to talk every day and indicated she could call on relatives day or night for help and for someone to talk with. Her relationship with her family was very important to her, and she was very satisfied with these relationships. She saw her son and his family daily, but her other children she saw less than once a year. She spoke with friends and siblings weekly and visited with them monthly.

Mrs. Haskins felt that it was very important to have new and different activities daily and that it was also very important to have similar activities from day-to-day. Mrs. Haskins was very satisfied with her activities which included crocheting and visiting.

It took nearly three weeks to set up the interview for the TSCS because of visiting relatives. When the interview took place Mrs. Haskins' son was not present, although she had discussed it with him the night before. Her daughter-in-law was present for part of it. At the time of the interview Mrs. Haskins and her daughter-in-law were talking about the bank which had indicated that Mrs. Haskins had spent more than she herself had recorded. She felt it was the bank's mistake and had been on the phone with them earlier. They called during the interview to say they would send some information to her. Mrs. Haskins was very attractive and well-dressed. She was sitting in a chair waiting for the interview. She answered the questions quickly and with very little comment. It seemed that she was in 
a hurry to finish the interview so that she could voice a major concern. She said that she had discussed it with her son and felt that if enough people mentioned it something might be done. Mrs. Haskins said that she went to the doctor three times a week and that the Senior Center provided transportation. Recently a sign appeared in the car requesting a donation of $\$ 2.85$ each way. Mrs. Haskins said that she could not afford it but had been paying a dollar for a round trip. She felt that this was still more than she could afford but at the same time felt guilty for not paying more. She indicated that others felt the same way. This was discussed for some time. She was encouraged to reduce the payment if she thought she needed to and it was suggested further that the transportation was a service for which only those who could afford it needed to pay.

Mrs. Haskins' total self-concept was near the sample mean. It is interesting to note that this score is positive when compared to the norm group. Mrs. Haskins scored high in the areas of identity and family self and low in the areas of self-satisfaction and social self. Her low self-criticism score was low and indicated inconsistency.

\section{Mrs. Roberts - Low Self-Concept}

In the Stage 1 interview the interviewer expressed doubts as to the accuracy of the information provided. She said that Mrs. Roberts, 88, showed signs of confusion and was somewhat distrustful. As the interviewer left, a neighbor came out to talk saying that "things are very bad over there."

Mrs. Roberts described her health as good for her age. In the past year she had spent no time in bed because of illness and had not 
been hospitalized. She said that she was able to go out alone and had been to the grocery store, the drug store, to the bus stop, and to church in the past week. In that week Mrs. Roberts had also visited in person with friends, neighbors, and others. It had been over a year since she had seen her son (her only child) or relatives. Mrs. Roberts said that she had one confidant.

Mrs. Roberts had trouble answering financial questions. She did not know how her level of living compared to that of others her age, but she did say that it was the same as it had been both one year and ten years before. Mrs. Roberts did not know how she would use extra money-probably on medicine and funeral expenses.

Mrs. Roberts agreed somewhat with the statements, "I am just as happy as when I was younger", and "As I grow older things seem better than I thought they would be". She strongly agreed with "I would not change my past life even if I could". She disagreed somewhat with "I expect some interesting and pleasant things to happen to me in the future".

In the Stage 2 interview Mrs. Roberts still felt that her health was good for her age, although she complained of arthritis in her knees and said that she worried frequently about her health. She could get out only with help. Mrs. Roberts' niece now lived with her. Mrs. Roberts said that she had lived in her neighborhood for 14 years and that it was a good place to live. However, she was only somewhat satisfied, wishing that people were more friendly and visited more often. She said that she spoke with neighbors about once a week and they visited monthly. She was not too satisfied with her relation- 
ships with them because "they don't neighbor back and forth."

Mrs. Roberts said that she did not know how important her relationship to her family was. She said that she spoke to her son about every six months and that he visited her less than once a year. She said that she was somewhat satisfied with her relationship with him but it would be nice if he lived closer.

Mrs. Roberts had three living brothers and sisters (out of 21) but saw and spoke to relatives less than once a year. She said she did not know how satisfied she was with these relationships. Similarly when asked about friends, it appeared to have been more than a year since she had seen them. The interviewer reported that Mrs. Roberts rambled as she talked about them. She answered "don't know" when asked how satisfied she was with her relationships with friends as well.

Mrs. Roberts felt it was somewhat important to have new and different activities from day to day and not too important to have similar activities. Mrs. Roberts said her activities included sitting in the house, going to church and going out with her niece's friends. The interviewer reported that Mrs. Roberts was very confused. During the TSCS portion of the interview, Mrs. Roberts often seemed uncertain. She had not remembered the interview. During the first portion of the interview she was cutting up cereal cartons. She seemed to find it more difficult to answer questions when she had completed this task. The yard and house were quite cluttered and untidy. She had several old pictures--some printed on pillow covers. She did not remember the people in the pictures. Her housekeeper (the 
niece, perhaps) was very pleasant. She had been there two years. Mrs. Roberts appeared to have a poor memory and had trouble answering the questions. There were many "I don't know[s]"; questions had to be repeated and explained and she often did not seem to answer appropriately. She said many of the same things over and over, such as "I'm the thirteenth child of 23 and my brothers and sisters used to say, 'here comes number 13'; 'don't trust number 13'." Toward the end, she was concerned with the reason for the interview and who was going to see it. This had to be explained several times. (At the conclusion of the interview, the housekeeper/niece extended an invitation to a Dowsing and faith healing convention where she was to be a speaker.)

Mrs. Roberts' total self-concept score was quite low, more than one standard deviation below the sample mean. She scored low in all areas of self-concept, had a low self-criticism score, and was inconsistent in her responses.

\section{Mrs. Seltzer - High Self-Concept}

At stage 1 Mrs. Seltzer, 67, was living with her husband in a high-rise for low income elderly. They had been there for two years. Mrs. Seltzer felt that her health was good for her age. She was able to go out alone and had been to the grocery store, post office, drug store, and to church within the previous week. The interviewer indicated that she was very stooped and had a bad knee.

Mrs. Seltzer felt that her level of living was about the same as that of others her age and that she was better off than a year or ten years before. Mrs. Seltzer and her husband made use of a number of 
services. They went to a congregate meal program once a week; the housing authority referred them to a social service agency which helped find them legal aid and which provided transportation on a number of occasions. Mr. and Mrs. Seltzer indicated that they had also received help from their clergyman.

The Seltzers had one son who lived ten minutes away from them; they had seen hin within the past month. Within this time they also had visited in person with friends. Within the past week Mrs. Seltzer had spoken in person with neighbors, others, and had called people on the telephone. It had been more than a year since she had visited in person with relatives.

Mrs. Seltzer strongly agreed with the following statements: "I am just as happy as when I was younger", "I expect some interesting and pleasant things to happen to me in the future", and "As I grow older things seem better than I thought they would be". She somewhat agreed with "I would not change my past life even if I could".

Throughout the interview Mr. Seltzer was in and out of the apartment. The interviewer said that he was there for about one-third of the interview and that he slowed down the interview with a number of stories.

Approxinately one year after this interview Mr. and Mrs. Seltzer were on a bus trip sponsored by a senior center. There was an accident and Mrs. Seltzer's leg was broken. She spent a month in the hospital and was then sent to a large nursing home. About four months later, at the time of the Stage 2 interview, her leg had mended well and she was anticipating moving into a home for the aged with her 
husband. The high-rise would not take her back, so she and her husband had to find other accommodations. The first part of the interview was conducted in the nursing home, while the second part (TSCS) was conducted in the home for the aged.

Mrs. Seltzer said that she thought the nursing home was a good place to live, but that it was not like home and it was hard being separated from her husband. Her doctor had told her that the nursing home was a good place with pleasant people, and Mrs. Seltzer agreed. (The nursing home had been surrounded by controversy two years earlier. The home had lost approval, several residents were moved and subsequently died.)

Mrs. Seltzer considered herself to be in good health, saying that she had never felt better.

In terms of soeial partiçpation, Mrs. Seltzer indicated that in the nursing home she rarely called people just to talk. However, several people called her. Specifically, the day before her sisterin-law (with whom she hadn't talked in a long time) had called. Mrs. Seltzer indicated that she could call on the staff day or night if she needed help or needed to talk to someone. She also indicated that her minister was someone with whom she could discuss anything that bothered her ("I have depended upon hin quite a bit").

The people in the nursing home didn't really visit with one another. Mrs. Seltzer said that some gather in the evening to watch television, but that she is only acquainted with her roommate. Mrs. seltzer was very satisfied with her relationships with other residents. Mrs. Seltzer's most obvious source of social support was her 
husband. He came by bus to visit her every day. A few days before the interview the doctor had told him that for his own health he should cut back his visits to every other day. Both Mr. and Mrs. Seltzer were quite anxious to be reunited at the home for the aged. The seltzers had one son. They used to care for foster children and had adopted their son. Mrs. Seltzer said that they had seen him only once since she had had her accident. This seemed to trouble her quite a bit.

Mrs. Seltzer reported seeing her friends less often since she had been in the nursing home; mostly because she had not been able to go to two church services a week. The previous Sunday she had been able to attend services with her husband and had seen many friends at that time.

After Mrs. Seltzer joined her husband in the home for the aged they were visited again. The home was an old building on a dirt road and seemed out of the way. The couple seemed very happy and contented with their living situation. Their room was furnished with a record player, cards, books, table games, etc. Mrs. Seltzer again talked about how well she felt. Relationships with their son, however, remained the same; he had not been to see them at all. This was very distressing and Mrs. Seltzer remarked that "we missed the boat with our son."

The seltzers both seemed to enjoy the interview very much. Mr. Seltzer was dominating and had to be reminded to let his wife answer the questions. He talked about how her memory was poor, but that "I try to be patient with her." Mrs. Seltzer was very easy-going and 
seemed rather shy, but did enjoy talking--especially about how she and her husband met and married, about church, and hopes for her son. Mr. Seltzer cried when talking about his sister who died in infancy. Mrs. Seltzer cried when thinking about the nursing home and at times was close to tears when discussing her son. Mrs. Seltzer's total selfconcept score was high, 1.07 standard deviations above the mean. She was above the mean in all areas except family self and moral-ethical self. Her score on this latter category was near the mean, which was itself a high score, more than one standard deviation above the norm group. Mrs. Seltzer's self-criticism score was low. Unlike many others, her responses were consistent.

24. Mrs. Morgan - High Self-Concept

At stage 1, Mrs. Morgan, age 83, had lived in a trailer (in excellent condition) for six and a half years. She described her health as being poor for her age and could get out only with help. She had one son and he lived in the metropolitan area. She had seen him in the last week. In the previous week she had also talked in person with neighbors, others, and had talked on the phone. She had seen a relative during the last month, but it had been between one and six months since she had talked in person with a friend. She had not been to a grocery store, bank, church, etc. for over a year.

Mrs. Morgan worried about her health and getting out in case of an emergency, but did not have other major concerns. She received help with housework from a woman from VISTA, but had not had other services. Mrs. Morgan felt. that her level of living was about the same as others her age, but worse than it had been ten years ago. 
The interviewer at stage 1 indicated that it was difficult to persuade Mrs. Morgan to take part in the study. Mrs. Morgan felt that many of the questions were very personal and had second thoughts about answering them.

1.irs. Morgan had had many physical problems following the stage 1 interview. She had fallen and broken her leg twice.-Her the first time she had been at the Rehabilitation fnstitute of oregon (RIO) and, against the advice of the doctor and her family, had returned to her trailer. She had been there two days when she fela and broke her leg again. She lay on the floor for one and a half hours before someone found her. She returned te. RIg and to angthex nuaging home ("a dump") and was then transferred to the facility where she lives now. Her doctor helped find the facility and Mrs. Morgan's daughter-in-law visited and liked 1t.

The home was fairly large with approximately 200 residents. It specialized in rehabilitation and there were several younger people there. Mrs. Morgan had one of the nicest rooms which was fairly large and had its own sink. Mrs. Morgan thought that the nursing home was very good and better than average.

Mrs. Morgan was somewhat satisfied with her relationships with other residents, although "half of the time some don't know what they're doing." She went on to say, "there are a few people with clear minds. I know one or two of them." It was difficult for Mrs. Morgan to meet people. She had nothing in common with her roommate. She was up in the morning for physical therapy and then went to chapel, but spent the rest of the day in bed. There was no cure for her 
condition and she felt that her health was fair for her age.

Mrs. Morgan's major form of social support came from her son. She felt that she could call on him at any time and that she could talk to him about things that bothered her. Her son and his family visited very week, about the same as prior to institutionalization. Mrs. Morgan was clearly proud of them, particularly of a grandson who had just started college. Mrs. Morgan said that she went to visit them once in a while, but that it was very difficult because of her physical condition.

Mrs. Morgan reported that she had less contact with friends and relatives, seeing them only every couple of months. Much of this was due to their old age, illness, and difficulty with transportation; however, Mrs. Morgan indicated that she saw them as often as before she moved to the nursing horne.

Mrs. Morgan's major activities were reading, devotions, and physical therapy. She was a college graduate and was very well read in several areas.

Mrs. Morgan was one of the few individuals who clearly remembered the first interview. When setting the appointment for the stage 2 interview, she made it clear that she did not wish to answer personal questions. It was suggested that all questions be asked but that she should indicate which ones she did not wish to answer; by the end of the interview she had answered all questions fully and had not objected to any of them. Evidently many of the qestions she considered too personal on the first interview concerned income. An additional explanation for her openness might be the open-ended nature of the 
interview and the fact that it revolved around a subject which she enjoyed.

Mrs. Morgan's total self-concept score was higher than many in the sample (.67 standard deviations above the mean). She was above the mean in all areas except physical self, which was near the sample mean. Mrs. Morgan's self-criticism score was low and there appeared to be some inconsistency of response. 